\title{
Egyszeres és kétszeres szinuszsorok és -integrálok egyenletes konvergenciája
}

\author{
Ph.D. értekezés
}

KóRUS PÉTER

Témavezető:

Dr. MórICZ FERENC

az MTA doktora

professzor emeritus

Matematika- és Számítástudományok Doktori Iskola

Szegedi Tudományegyetem

Természettudományi és Informatikai Kar

Bolyai Intézet

Szeged

2012 


\section{Tartalomjegyzék}

$\begin{array}{ll}\text { Bevezetés } & 1\end{array}$

1. Szinuszsorok 4

1.1. Történeti áttekintés . . . . . . . . . . . . . . . . . . . . . 4

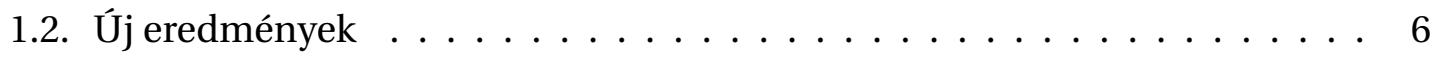

1.3. Az állítások igazolása . . . . . . . . . . . . . . . . . . 7

1.4. Formális deriválás és integrálás . . . . . . . . . . . . . . . . . . . 12

2. Kettős szinuszsorok $\quad 14$

2.1. A reguláris konvergencia . . . . . . . . . . . . . . . . . . . . . 14

2.2. Az NBVDS és MVBVDS osztályok . . . . . . . . . . . . . . . . . 15

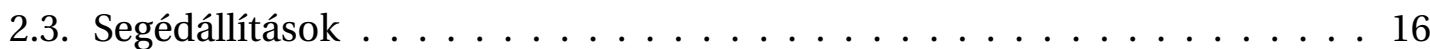

2.4. A 2.2.1. és 2.2.2. Tételek bizonyítása . . . . . . . . . . . . . . . . 18

2.5. Az SBVDS Sés SBVDS $_{2}$ osztályok . . . . . . . . . . . . . . . . 24

2.6. A 2.5.1. és 2.5.2. Tételek bizonyítása . . . . . . . . . . . . . . . . . . . 25

3. Szinuszintegrálok 30

3.1. Előzmények . . . . . . . . . . . . . . . . . . . . 30

3.2. Új eredmények . . . . . . . . . . . . . . . . . . . . . 32

3.3. Az állítások igazolása . . . . . . . . . . . . . . . . . . . . . . 33

3.4. Formális deriválás és integrálás . . . . . . . . . . . . . . . . . 37

4. Kettős szinuszintegrálok $\quad 40$

4.1. Kettős integrálok konvergenciája . . . . . . . . . . . . . . . . . . 40

4.2. Új eredmények . . . . . . . . . . . . . . . . . . . . . . . 42

4.3. Segédállítások . . . . . . . . . . . . . . . . . . 44

4.4. A 4.2.1. és 4.2.2. Tételek bizonyítása . . . . . . . . . . . . . . . . . 46

$\begin{array}{lr}\text { Irodalomjegyzék } & 54\end{array}$ 
Összefoglalás $\quad 56$

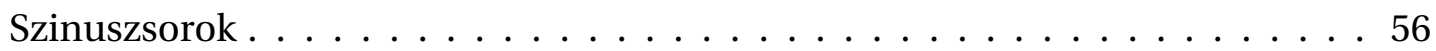

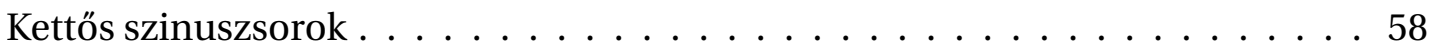

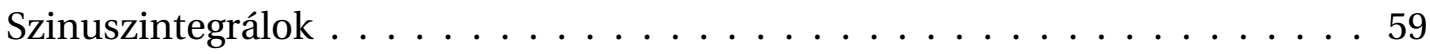

Kettős szinuszintegrálok . . . . . . . . . . . . . . . . . 61

$\begin{array}{ll}\text { Summary } & 63\end{array}$

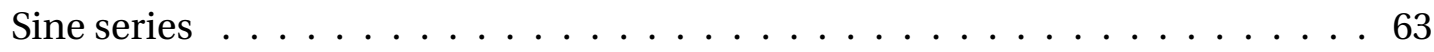

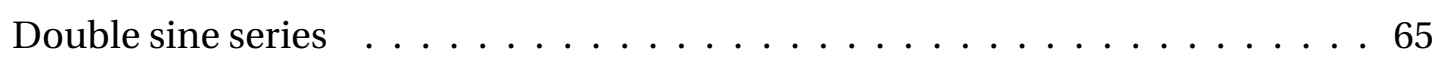

Sine integrals . . . . . . . . . . . . . . . . . 66

Double sine integrals . . . . . . . . . . . . . . . . 68 


\section{Bevezetés}

Kutatásom kiindulópontja S. P. Zhou, P. Zhou és D. S. Yu 2006-os [16] cikke volt, amelyben szinuszsorok egyenletes konvergenciájával foglalkoznak a szerzők. A témakörben klasszikusnak tekinthető tétel T. W. Chaundy és A. E. Jolliffe nevéhez füződik, akik 1916os [1] cikkükben adtak szükséges és elegendő feltételt a nemnegatív, monoton nemnövő együtthatójú szinuszsorok egyenletes konvergenciájára. A XX. század második felében kvázimonoton sorozatosztályok bevezetésével (CQMS, RVQMS) megmutatták, hogy a klasszikus feltétel szükséges és elegendő marad az újonnan definiált együtthatójú sorok esetében is. A 2000-es években Leindler László az RBVS osztályt új koncepció alapján definiálta, a sorozat változásának korlátozása lett az együtthatók monotonitási feltételének enyhítése felé. Leindler a Chaundy-Jolliffe-tétel kiterjesztése mellett bebizonyította, hogy az RBVS és a kvázimonoton sorozatosztályok nem összehasonlíthatók. Később R. J. Le és S. P. Zhou GBVS osztálya már a kvázimonoton sorozatokat és RBVS-t is tartalmazta, ezen osztályt pedig tovább általánosította az NBVS és az S. P. Zhou, P. Zhou és D. S. Yu által 2006-ban definiált MVBVS sorozatosztály. Az általánosított monoton sorozatosztályok definícióiban pedig azt is megengedték, hogy a szinuszsorok együtthatóiról nem feltétlenül nemnegatív sorozat elemei legyenek, sőt, akár komplex számok is lehetnek.

Az MVBVS osztályt, a Chaundy-Jolliffe-tétel kiterjesztéséhez megfelelő, akkori legbővebb osztályt sikerült általánosítanom 2009-ben [4]-ben, az SBVS és $\mathrm{SBVS}_{2}$ fogalmak definiálásával. Az SBVS fogalmat S. Tikhonov [13]-beli általánosított monoton sorozatosztály konstrukciója ihlette, ugyanakkor [13]-ban Fourier-sorok (szinuszsorok, koszinuszsorok, vagy akár komplex trigonometrikus sorok) $L^{1}$-konvergenciáját vizsgálta a szerző. Trigonometrikus sorok esetében az egyenletes konvergencia és a $L^{1}$ konvergencia közti párhuzamot jól mutatja az a tény, hogy a két témakörben alapvető tételeket, melyeket nemnegatív, monoton nemnövő együtthatójú sorokra fogalmaztak meg, egyaránt általánosították MVBVS-beli együtthatójú sorokra. Az egyenletes konvergencia problémájára nemcsak a szinusz-, hanem a koszinuszsorok és a komplex trigonometrikus sorok esetében is vannak eredmények, azonban a dolgozatban csak 
a szinuszsorokat (később szinuszintegrálokat) vizsgáljuk. Megjegyzendő, hogy a [3] cikkben is bizonyítanak állításokat valós trigonometrikus sorok egyenletes konvergenciájára, ezen cikk azonban [4] megírásakor még nem volt számomra elérhető. [3]-ban az általánosított monoton sorozatosztályokat általános esetben vizsgálják, míg [4]-ben konkrét osztályokat és sorozatokat adunk meg, és azokra bizonyítunk állításokat. A Chaundy-Jolliffe-tétel kiterjesztéséhez megfelelő legbővebb sorozatosztály a [4]-beli $\mathrm{SBVS}_{2}$ osztály.

Érdemes megemlíteni azt a tényt is, hogy ha egy szinuszsor egyenletesen konvergens, akkor mivel az egyenletes konvergencia megőrzi a folytonosságot, a sor összegfüggvénye folytonos. Megfordítva, ha egy folytonos függvény Fourier-sorának (szinuszsorának) együtthatói nemnegatívak, akkor a Fourier-sor egyenletesen konvergál a függvényhez (lásd [7, 12]).

A kettős szinuszsorok egyenletes konvergenciájára az egyszeres szinuszsorokhoz képest kevesebb eredmény ismert. Kettős sorok esetében többféle konvergenciafogalom használatos: a Pringsheim-féle konvergencia és az annál erősebb reguláris konvergencia. A kettős szinuszsorok reguláris konvergenciájának egyenletességére I. E. Žak és A. A. Šneider 1966-os, orosz nyelvű [14] cikke szolgáltat szükséges és elegendő feltételt nemnegatív, monoton nemnövő együtthatójú sorok esetén. Az ottani feltétel természetesen elegendő a Pringsheim-féle konvergencia egyenletességéhez is, azonban nem szükséges ahhoz. 2009-ben Móricz Ferenccel közös cikkünkben, [7]-ben általánosítottuk Žak és Šneider tételét az MVBVDS osztály segítségével, mely az MVBVS mintájára definiált, általánosított monoton, kettős sorozatok osztálya. Ezen cikkben már a reguláris konvergencia Móricz-féle [9]-beli formáját használjuk, nem a Žak és Šneider által alkalmazott formáját. Legfrissebb eredményként pedig MVBVDS-t tovább általánosítottam [6]-ban, és beláttam a [14] és [7]-beli tételek eddigi (általam ismert) legbővebb kiterjesztését.

Bár a Fourier integrálokkal számos szerző foglalkozott, az egyenletes konvergenciára vonatkozóan kevés eredmény található. Kutatásomat Móricz Ferenc [10] cikke indította el, melyben az $\mathbb{R}_{+}$pozitív félegyenesen definiált szinuszintegrálok egyenletes konvergenciájára adott feltételrendszer hasonló a szinuszsorok esetében megfogalmazottal. A diszkrét esettel analóg módon itt függvények változásának korlátozása célszerű, ami által általánosított monoton függvényosztályok keletkeznek. Amellett, hogy Móricz a nemnegatív, monoton nemnövő függvény által meghatározott szinuszintegrálok egyenletes konvergenciáját jellemezte [10]-ben, az általa bevezetett $\operatorname{MVBVF}\left(\mathbb{R}_{+}\right)$ általánosított monoton függvényosztályra is igazolt tételeket. Ezen eredményeket bővítettem ki [5]-ben az $\operatorname{SBVF}\left(\mathbb{R}_{+}\right)$és $\operatorname{SBVF}_{2}\left(\mathbb{R}_{+}\right)$függvényosztályok bevezetésével. Bár az 
iménti osztályok definíciói nem triviálisak, természetességüket mutatja az a tény, hogy olyan egyszerű függvények is oda tartoznak, mint például a $\sin x$ vagy a $\cos x$, mely függvények nem $\operatorname{MVBVF}\left(\mathbb{R}_{+}\right)$-beliek. Megjegyzendő, hogy a Fourier integrálok egyenletes konvergenciájára vonatkozóan a [2] cikkben is találhatók eredmények, melyeket a [5] cikkem megírásakor még nem ismertem. [2]-ben az általánosított monoton függvényosztályokat általános esetben vizsgálják, [5]-ben viszont konkrét függvényosztályokat és példafüggvényeket adunk meg, és azokra bizonyítunk állításokat.

Az első síknegyeden definiált kettős szinuszintegrálok egyenletes konvergenciájával [8]-ban foglalkozunk. A disszertáció négy témája közül ez tekinthető a legfrissebbnek, ezen témakör vizsgálata jelenleg újdonságnak számít. A [8]-ban elért eredmények és az egyszeres szinuszintegrálokra ill. a kettős szinuszsorokra kapott eredmények között természetesen felfedezhető analógia, azonban triviális kiterjesztésről nem beszélhetünk, elegendő például a - kettős integrálok esetén nem széles körben ismert - reguláris konvergencia fogalmára gondolni. 


\section{1. fejezet}

\section{Szinuszsorok}

\subsection{Történeti áttekintés}

Szinuszsornak nevezzük a

$$
\sum_{k=1}^{\infty} c_{k} \sin k x
$$

alakú végtelen összeget, ahol a $\left\{c_{k}\right\}_{k=1}^{\infty}$ együtthatók komplex számok. Ezen összeg minden tagjában $2 \pi$ szerint periodikus, páratlan függvény szerepel, így az (1.1) egyenletes konvergenciájának vizsgálatakor elegendő az $x \in[0, \pi]$ esetet figyelnünk. A $\left\{c_{k}\right\}$ jelölés a fejezet során mindvégig az 1-es indexű tagtól indul, viszont szükség szerint $c_{0}=0$. A szinuszsorok egyenletes konvergenciájának elméletében alapvető tételt Chaundy és Jolliffe 1916-ban igazolta [1]-ben. Olyan szinuszsorokat vizsgáltak, melyek együtthatói monoton nemnövők, azaz $c_{1} \geq c_{2} \geq \ldots$, másképpen fogalmazva, $\Delta c_{k} \geq 0$ bármely $k \geq 1$ esetén, ahol $\Delta c_{k}=c_{k}-c_{k+1}$.

1.1.1. Tétel. [1] Ha $a\left\{c_{k}\right\} \subset \overline{\mathbb{R}}_{+}:=[0, \infty)$ monoton nemnövö, O-hoz tartó sorozat, akkor az (1.1) szinuszsor akkor és csak akkor egyenletesen konvergens $x$-ben, ha

$$
k c_{k} \rightarrow 0, \quad h a \quad k \rightarrow \infty
$$

Az 1.1.1. Tételnek azóta számos általánosítása ismert. Az általánosításokban a tételbeli monotonitási feltételt enyhítik a szerzők úgy, hogy az (1.2) feltétel továbbra is szükséges és elegendő maradjon. Így a nemnegatív, monoton nemnövő sorozatoknál bővebb sorozatosztályokat definiáltak, melyek akár komplex számokat is tartalmazhatnak. Ezen osztályok közül néhány definícióját érdemes megemlíteni (további példák találhatók [16]-ban): 
$\left\{c_{k}\right\} \in$ RBVS (Rest Bounded Variation Sequences), ha létezik (n-től független) $C$ konstans, melyre

$$
\sum_{k=n}^{2 n-1}\left|\Delta c_{k}\right| \leq C\left|c_{n}\right|
$$

$\left\{c_{k}\right\} \in$ GBVS (Group Bounded Variation Sequences), ha léteznek $C, N_{0} \geq 1$ konstansok, melyekre

$$
\sum_{k=n}^{2 n-1}\left|\Delta c_{k}\right| \leq C \max _{n \leq k \leq n+N_{0}}\left|c_{k}\right|
$$

Az NBVS osztály fogalmát D. S. Yu és S. P. Zhou 2006-ban vezette be [15]-ben: $\left\{c_{k}\right\} \in$ NBVS (Non-onesided Bounded Variation Sequences), ha létezik $C$ konstans, melyre

$$
\sum_{k=n}^{2 n-1}\left|\Delta c_{k}\right| \leq C\left(\left|c_{n}\right|+\left|c_{2 n}\right|\right)
$$

S. P. Zhou, P. Zhou és D. S. Yu ugyanazon évben az MVBVS osztályt definiálta [16]ban: $\left\{c_{k}\right\} \in$ MVBVS (Mean Value Bounded Variation Sequences), ha léteznek $C, \lambda \geq 2$ konstansok, melyek teljesítik a

$$
\sum_{k=n}^{2 n-1}\left|\Delta c_{k}\right| \leq \frac{C}{n} \sum_{k=[n / \lambda]}^{[\lambda n]}\left|c_{k}\right|
$$

feltételt, ahol a [.] jelölés a valós szám egész részét jelöli. [15]-ben belátták, hogy NBVS tartalmazza az 1.1.1. Tétel általánosításához megfelelő, addig legbővebbnek tekinthető sorozatosztályt, GBVS-t, valamint [16]-ban az MVBVS $\supsetneqq$ NBVS tartalmazást igazolták (pontos levezés található [7]-ben). Továbbá bebizonyították a következő állítást, a klasszikus tétel addigi legbővebb kiterjesztését:

1.1.2. Tétel. [16] Legyen $\left\{c_{k}\right\} \subset \mathbb{C}$ sorozat MVBVS-beli.

(i) Ha (1.2) teljesül, akkor (1.1) egyenletesen konvergens $x$-ben.

(ii) Megfordítva, ha $\left\{c_{k}\right\} \subset \overline{\mathbb{R}}_{+}$és (1.1) konvergenciája egyenletes $x$-ben, (1.2) fennáll.

Későbbi eredményeink szempontjából érdemes kiemelni az előző tétel bizonyításából két részeredményt, melyeket a bizonyítás technikájának megmutatásaként be is bizonyítunk.

1.1.3. Lemma. Legyen $\left\{c_{k}\right\} \in$ MVBVS. Tegyük fel, hogy $n c_{n} \rightarrow 0$, ha $n \rightarrow \infty$. Ekkor

$$
n \sum_{k=n}^{\infty}\left|\Delta c_{k}\right| \rightarrow 0, \text { ha } n \rightarrow \infty
$$

Bizonyítás. Legyen $\varepsilon>0$ tetszőleges, és $n_{0}=n_{0}(\varepsilon) \geq \lambda$ az a pozitív egész szám, melyre bármely $n>n_{0}$ esetén $n\left|c_{n}\right| \leq \varepsilon$. Ekkor az (1.3) feltétel szerint bármely $n>n_{0}$ esetén

$$
\sum_{k=n}^{\infty}\left|\Delta c_{k}\right|=\sum_{r=0}^{\infty} \sum_{k=2^{r} n}^{2^{r+1} n-1}\left|\Delta c_{k}\right| \leq C \sum_{r=0}^{\infty} \frac{1}{2^{r} n} \sum_{k=\left[2^{r} n / \lambda\right]}^{\left[\lambda 2^{r} n\right]}\left|c_{k}\right|
$$




$$
\leq \frac{C \varepsilon}{n} \sum_{r=0}^{\infty} \frac{1}{2^{r}} \sum_{k=\left[2^{r} n / \lambda\right]}^{\left[\lambda 2^{r} n\right]} \frac{1}{k} \leq \frac{2 \lambda^{2} C \varepsilon}{n} \sum_{r=0}^{\infty} \frac{1}{2^{r}}=\frac{4 \lambda^{2} C \varepsilon}{n},
$$

hiszen

$$
\sum_{k=\left[2^{r} n / \lambda\right]}^{\left[\lambda 2^{r} n\right]} \frac{1}{k} \leq\left[\lambda 2^{r} n\right] \cdot \frac{1}{\left[2^{r} n / \lambda\right]} \leq 2 \lambda^{2} \text { ha } n \geq \lambda, r \geq 0 .
$$

1.1.4. Lemma. Legyen $\left\{c_{k}\right\} \subset \overline{\mathbb{R}}_{+}$MVBVS-beli. Ekkor

$$
n c_{n} \leq(C+1) \sum_{k=[n / 2 \lambda]}^{[\lambda n]} c_{k},
$$

ahol C és $\lambda$ az MVBVS-beli definícióban szereplö, $\left\{c_{k}\right\}$-hoz tartozó konstansok.

Bizonyítás. Legyen $n$ tetszőleges. Ekkor bármely $n+1 \leq v \leq 2 n$ egész számra

$$
c_{n} \leq \sum_{k=n}^{v-1}\left|\Delta c_{k}\right|+c_{v} \leq \sum_{k=n}^{2 n-1}\left|\Delta c_{k}\right|+c_{v} \leq \frac{C}{n} \sum_{k=[n / \lambda]}^{[\lambda n]} c_{k}+c_{v} .
$$

Összegezve az előbb kapott egyenlőséget $v=n+1, \ldots, 2 n$-re kapjuk, hogy

$$
n c_{n} \leq C \sum_{k=[n / \lambda]}^{[\lambda n]} c_{k}+\sum_{v=n+1}^{2 n} c_{v} \leq(C+1) \sum_{k=[n / 2 \lambda]}^{[\lambda n]} c_{k} .
$$

\section{2. Új eredmények}

Célunk az MVBVS osztály kibővítése volt úgy, hogy az 1.1.2. Tétel állításai igazak maradjanak az új sorozatosztály mellett is. A következő osztály fogalmát [4]-ben vezettük be, amit a S. Tikhonov [13] cikkében szereplő ${ }_{6} \beta$ konstrukció ihletett (az ott szereplő maximum azonban nem feltétlenül létezik, így szuprémum használata célszerű).

Definíció. A $\left\{c_{k}\right\} \subset \mathbb{C}$ sorozatot Supremum Bounded Variation Sequence-nek nevezzük, jelben $\left\{c_{k}\right\} \in$ SBVS, ha léteznek olyan $C$ és $\lambda \geq 1$ konstans számok, melyek csak $\left\{c_{k}\right\}$-tól függnek, és

$$
\sum_{k=n}^{2 n-1}\left|\Delta c_{k}\right| \leq \frac{C}{n} \sup _{m \geq[n / \lambda]} \sum_{k=m}^{2 m}\left|c_{k}\right|
$$

fennáll minden $n \geq 1$ esetén.

Továbbá észrevettük, hogy az (1.4)-ben szereplő felső korlátban az összegzést indíthatjuk akár $[n / \lambda]$-nál lentebbről is, csak az összegzés alsó határa tartson végtelenbe, ha $n$ tart a végtelenbe. Így kapjuk az $\mathrm{SBVS}_{2}$ fogalmát. 
Definíció. A $\left\{c_{k}\right\} \subset \mathbb{C}$ sorozatot Supremum Bounded Variation Sequence of 2nd typenak nevezzük, jelben $\left\{c_{k}\right\} \in \mathrm{SBVS}_{2}$, ha létezik olyan $C$ konstans és végtelenbe tartó $\{b(k)\}_{k=1}^{\infty} \subset \overline{\mathbb{R}}_{+}$sorozat, melyek csak $\left\{c_{k}\right\}$-tól függnek, és amelyekre

$$
\sum_{k=n}^{2 n-1}\left|\Delta c_{k}\right| \leq \frac{C}{n} \sup _{m \geq b(n)} \sum_{k=m}^{2 m}\left|c_{k}\right| .
$$

Megjegyezzük, hogy ha a definícióbeli $\{b(k)\}$ sorozattól elvárjuk, hogy monoton nemcsökkenő legyen, akkor ugyanazon $\left\{c_{k}\right\}$ sorozatok maradnak $\mathrm{SBVS}_{2}$-ben (hiszen tetszőleges $\{b(k)\}$ sorozat helyettesíthető egy monoton nemcsökkenő $\left\{b^{\prime}(k):=\min _{l \geq k} b(l)\right\}$ sorozattal).

Megmutatjuk, hogy az SBVS $_{2}$, SBVS, MVBVS osztályok között valódi tartalmazási reláció áll fenn.

1.2.1. Tétel. [4] $\mathrm{SBVS}_{2} \supsetneqq \mathrm{SBVS} \supsetneqq \mathrm{MVBVS}$.

Az 1.1.2. Tétel általánosítása a következő:

1.2.2. Tétel. [4] Legyen $\left\{c_{k}\right\} \subset \mathbb{C}$ sorozat $\mathrm{SBVS}_{2}$-beli.

(i) Ha (1.2) teljesül, akkor (1.1) egyenletesen konvergens $x$-ben.

(ii) Megfordítva, ha $\left\{c_{k}\right\} \subset \overline{\mathbb{R}}_{+}$és (1.1) konvergenciája egyenletes $x$-ben, akkor (1.2) fennáll.

1.2.3. Következmény. Ha $a\left\{c_{k}\right\} \subset \overline{\mathbb{R}}_{+}$sorozat $\mathrm{SBVS}_{2}$-beli, akkor (1.2) szükséges és elegendö feltétel az (1.1) sor x-ben vett egyenletes konvergenciájához.

Végül egy észrevételt teszünk az $\mathrm{SBVS}_{2} \backslash \mathrm{SBVS}$-beli sorozatokra.

1.2.4. Állítás. [4] Bármely olyan $\mathrm{SBVS}_{2}$-beli sorozatra, mely nem SBVS-beli, (1.2) fennáll. Azaz az ilyen együtthatójú szinuszsorok egyenletesen konvergensek.

\subsection{Az állítások igazolása}

Az 1.2.1. Tétel bizonyítása. Először megmutatjuk, hogy SBVS $\supseteq$ MVBVS. Legyen $\left\{c_{k}\right\} \in$ MVBVS a $C$ és $\lambda$ konstansokkal. Ekkor (1.3) szerint bármely $n \geq \lambda$-ra

$$
\begin{aligned}
\sum_{k=n}^{2 n-1}\left|\Delta c_{k}\right| & \leq \frac{C}{n} \sum_{k=[n / \lambda]}^{[\lambda n]}\left|c_{k}\right| \leq \frac{C}{n}\left(\sum_{k=[n / \lambda]}^{2[n / \lambda]-1}\left|c_{k}\right|+\ldots+\sum_{k=\lambda^{2}[n / \lambda]}^{2 \lambda^{2}[n / \lambda]-1}\left|c_{k}\right|\right) \\
& \leq \frac{2 \lambda^{2} C}{n} \sup _{m \geq[n / \lambda]} \sum_{k=m}^{2 m}\left|c_{k}\right| .
\end{aligned}
$$


Mivel véges sok $(1 \leq n<\lambda)$ esetben nem adtunk becslést a bal oldalon szereplő kifejezésre, ezért létezik $C_{1}$ konstans, melyre a

$$
\sum_{k=n}^{2 n-1}\left|\Delta c_{k}\right| \leq C_{1} \sup _{m \geq[n / \lambda]} \sum_{k=m}^{2 m}\left|c_{k}\right|
$$

becslés érvényes minden $1 \leq n<\lambda$-re. Tehát $\left\{c_{k}\right\} \in \operatorname{SBVS}$ a max $\left\{2 \lambda^{2} C, C_{1}\right\}$ és $\lambda$ konstansokkal.

Második lépésben megadunk egy olyan példasorozatot, mely SBVS-beli, de nem MVBVS-beli. Ezen $\left\{c_{k}\right\}$ legyen a következő: adjuk meg a pozitív számoknak egy nemnövő $\left\{d_{j}\right\}_{j=1}^{\infty}$ sorozatát, legyen $n_{j}=2^{\left(2^{2 j}\right)}(j=1,2, \ldots)$ és

$$
c_{k}:=\left\{\begin{array}{lll}
0, & \text { ha } \quad k<n_{1}, \\
d_{j}, & \text { ha } \quad k=n_{j}, \\
0, & \text { ha } \quad n_{j}<k<n_{j}^{2}, \\
d_{j}, & \text { ha } \quad n_{j}^{2} \leq k<2 n_{j}^{2}, \\
0, & \text { ha } 2 n_{j}^{2} \leq k<n_{j+1} .
\end{array}\right.
$$

Megmutatjuk, hogy $\left\{c_{k}\right\}$ nem MVBVS-beli. Indirekt módon bizonyítjuk állításunkat. Tegyük fel, hogy $\left\{c_{k}\right\} \in$ MVBVS a $C$ és $\lambda \geq 2$ konstansokkal. Ekkor

$$
\sum_{k=n_{j}}^{2 n_{j}-1}\left|\Delta c_{k}\right|=d_{j}
$$

és elég nagy $j$-re

$$
\frac{C}{n_{j}} \sum_{k=\left[n_{j} / \lambda\right]}^{\left[\lambda n_{j}\right]}\left|c_{k}\right|=\frac{C}{n_{j}} d_{j}
$$

ez pedig ellentmont (1.3)-nak, hiszen elég nagy $j$-re

$$
\sum_{k=n_{j}}^{2 n_{j}-1}\left|\Delta c_{k}\right|=d_{j}>\frac{C}{n_{j}} d_{j}=\frac{C}{n_{j}} \sum_{k=\left[n_{j} / \lambda\right]}^{\left[\lambda n_{j}\right]}\left|c_{k}\right| .
$$

Tehát $\left\{c_{k}\right\} \notin$ MVBVS. Másrészről, $n_{j} / 2 \leq n \leq n_{j}$-re

$$
\sum_{k=n}^{2 n-1}\left|\Delta c_{k}\right| \leq 2 d_{j}=\frac{2}{n_{j}^{2}} \sum_{k=n_{j}^{2}}^{2 n_{j}^{2}}\left|c_{k}\right| \leq \frac{1}{n} \sup _{m \geq n} \sum_{k=m}^{2 m}\left|c_{k}\right|,
$$

$n_{j}^{2} / 2 \leq n \leq 2 n_{j}^{2}$-re

$$
\sum_{k=n}^{2 n-1}\left|\Delta c_{k}\right| \leq 2 d_{j}=\frac{2}{n_{j}^{2}} \sum_{k=n_{j}^{2}}^{2 n_{j}^{2}}\left|c_{k}\right| \leq \frac{4}{n} \sup _{m \geq[n / 2]} \sum_{k=m}^{2 m}\left|c_{k}\right|
$$


és a maradék $n$ érték esetén

$$
\sum_{k=n}^{2 n-1}\left|\Delta c_{k}\right|=0 \leq \frac{1}{n} \sup _{m \geq n} \sum_{k=m}^{2 m}\left|c_{k}\right|
$$

Tehát $\left\{c_{k}\right\} \in$ SBVS a $C=4$ és $\lambda=2$ konstansokkal. Érdemes megjegyezni, hogy a $\left\{d_{j}\right\}$ sorozatot választhatjuk úgy, hogy $\left\{c_{k}\right\}$ teljesítse (1.2)-t, de úgy is, hogy ne.

$\mathrm{Az} \mathrm{SBVS}_{2} \supseteq \mathrm{SBVS}$ tartalmazási reláció a $b(n)=[n / \lambda]$ helyettesítéssel könnyen látható.

Végül, konstruálunk egy SBVS $_{2} \backslash$ SBVS-beli sorozatot. Az előző példához hasonlóan definiálunk. Legyen $\left\{d_{j}\right\}_{j=1}^{\infty}$ nemnövő, pozitív számsorozat, $n_{j}=2^{\left(2^{2 j}\right)}(j=1,2, \ldots)$ és

$$
c_{k}:= \begin{cases}0, & \text { ha } k<n_{1}, \\ d_{j} n_{j}^{-2}, & \text { ha } k=n_{j}, \\ 0, & \text { ha } n_{j}<k<n_{j}^{2} \\ d_{j+1} n_{j+1}^{-3 / 2}, & \text { ha } n_{j}^{2} \leq k \leq 2 n_{j}^{2}, \\ 0, & \text { ha } 2 n_{j}^{2}<k<n_{j+1} .\end{cases}
$$

Indirekt tegyük fel, hogy $\left\{c_{k}\right\} \in$ SBVS a $C$ és $\lambda$ konstansokkal. Ekkor

$$
\sum_{k=n_{j}}^{2 n_{j}-1}\left|\Delta c_{k}\right|=2 \frac{d_{j}}{n_{j}^{2}}
$$

és elég nagy $j$-re

$$
\frac{C}{n_{j}} \sup _{m \geq\left[n_{j} / \lambda\right]} \sum_{k=m}^{2 m}\left|c_{k}\right|=\frac{C}{n_{j}} \max \left\{\sup _{k \geq j} \frac{d_{k}}{n_{k}^{2}}, \sup _{k>j} n_{k}^{1 / 2} \frac{d_{k}}{n_{k}^{3 / 2}}\right\}=C \frac{d_{j}}{n_{j}^{3}},
$$

ezért elég nagy $j$-re (1.4) nem áll fenn, ez pedig ellentmondás. Tehát $\left\{c_{k}\right\} \notin \operatorname{SBVS}$. Ellenben könnyen meggondolható, hogy $\left\{c_{k}\right\} \in \mathrm{SBVS}_{2}$, csak az $n_{j} / 2 \leq n \leq n_{j}$ eset érdekes, amikor is

$$
\sum_{k=n}^{2 n-1}\left|\Delta c_{k}\right| \leq 2 \frac{d_{j}}{n_{j}^{2}}=\frac{2}{n_{j}} \sum_{k=n_{j}^{1 / 2}}^{2 n_{j}^{1 / 2}}\left|c_{k}\right| \leq \frac{2}{n} \sum_{k=n_{j}^{1 / 2}}^{2 n_{j}^{1 / 2}}\left|c_{k}\right| .
$$

Az 1.2.2. Tétel bizonyítása előtt bebizonyítunk két, az 1.1.3. és 1.1.4.-hez hasonló lemmát.

1.3.1. Lemma. Legyen $\left\{c_{k}\right\} \in \mathrm{SBVS}_{2}$. Ha tetszöleges $\varepsilon>0$-hoz létezik $n_{0}=n_{0}(\varepsilon)$ úgy, hogy bármely $n>n_{0}$ esetén $n\left|c_{n}\right| \leq \varepsilon$, akkor létezik olyan $n_{1}$, melyre bármely $n>n_{1}$ esetén $b(n)>n_{0}$. Továbbá bármely $n>n_{1}$-ra fennáll a

$$
\sum_{k=n}^{\infty}\left|\Delta c_{k}\right| \leq \frac{4 C \varepsilon}{n}
$$


összefüggés. Azaz ha (1.2) fennáll, akkor

$$
n \sum_{k=n}^{\infty}\left|\Delta c_{k}\right| \rightarrow 0, \text { ha } n \rightarrow \infty
$$

Bizonyítás. Mivel $b(n)$ a végtelenbe tart, $n_{1}$ létezése evidens. Használva (1.5)-öt, bármely $n>n_{1}$ esetén

$$
\begin{aligned}
\sum_{k=n}^{\infty}\left|\Delta c_{k}\right| & =\sum_{r=0}^{\infty} \sum_{k=2^{r} n}^{2^{r+1} n-1}\left|\Delta c_{k}\right| \leq C \sum_{r=0}^{\infty} \frac{1}{2^{r} n} \sup _{m \geq b\left(2^{r} n\right)} \sum_{k=m}^{2 m}\left|c_{k}\right| \\
& \leq \frac{C \varepsilon}{n} \sum_{r=0}^{\infty} \frac{1}{2^{r}} \sup _{m \geq b\left(2^{r} n\right)} \sum_{k=m}^{2 m} \frac{1}{k} \leq \frac{2 C \varepsilon}{n} \sum_{r=0}^{\infty} \frac{1}{2^{r}}=\frac{4 C \varepsilon}{n} .
\end{aligned}
$$

1.3.2. Lemma. Legyen $\left\{c_{k}\right\} \subset \overline{\mathbb{R}}_{+} \mathrm{SBVS}_{2}$-beli. Ekkor

$$
n c_{n} \leq C \sup _{m \geq b(n)} \sum_{k=m}^{2 m} c_{k}+\sum_{k=n}^{2 n} c_{k}
$$

ahol C és b(n) az $\mathrm{SBVS}_{2}$-beli definícióban szereplő, $\left\{c_{k}\right\}$-hoz tartozó konstans ill. sorozat.

Bizonyítás. Hasonlóan az 1.1.4. Lemma bizonyításához, világos, hogy

$$
n c_{n} \leq \sum_{v=n+1}^{2 n} \sum_{k=n}^{v-1}\left|\Delta c_{k}\right|+c_{v} \leq \sum_{v=n+1}^{2 n} \sum_{k=n}^{2 n-1}\left|\Delta c_{k}\right|+\sum_{v=n}^{2 n} c_{v} \leq C \sup _{m \geq b(n)} \sum_{k=m}^{2 m} c_{k}+\sum_{k=n}^{2 n} c_{k} .
$$

Az 1.2.2. Tétel bizonyítása. Legyen $\left\{c_{k}\right\} \in \mathrm{SBVS}_{2}$ a hozzátartozó $C$ konstanssal és $b(k)$ sorozattal.

(i) rész: Tegyük fel, hogy (1.2) fennáll. Ekkor létezik az 1.3.1. Lemma szerinti $n_{0}$ és $n_{1}$. Be fogjuk látni, hogy bármely $N \geq n>n_{2}:=\max \left\{n_{0}, n_{1}\right\}$ esetén

$$
|s(n, N ; x)|:=\left|\sum_{k=n}^{N} c_{k} \sin k x\right| \leq(4 C \pi+2 \pi+1) \varepsilon .
$$

Mivel $s(n, N ; 0)=s(n, N ; \pi)=0$, ezért elegendő az $x \in(0, \pi)$ esettel foglalkoznunk. Legyen $v:=[1 / x]$. Ekkor bármely $n_{2}<n \leq N \leq v$ esetén

$$
|s(n, N ; x)| \leq x \sum_{k=n}^{N} k\left|c_{k}\right| \leq \frac{1}{v} \sum_{k=n}^{v} \varepsilon \leq \varepsilon,
$$

hiszen $0<y<1$ esetén $\sin y \leq y$.

Továbbá, egy Abel-átrendezés után (lásd [17, 3.oldal]) az 1.3.1.Lemmát alkalmazva kapjuk, hogy bármely $\max \left\{n_{2}, v\right\}<n \leq N$ esetén

$$
|s(n, N ; x)| \leq \sum_{k=n}^{N-1}\left|\Delta c_{k}\right|\left|\widetilde{D}_{k}(x)\right|+\left|c_{N}\right|\left|\widetilde{D}_{N}(x)\right|+\left|c_{n}\right|\left|\widetilde{D}_{n-1}(x)\right|
$$




$$
\begin{aligned}
& \leq \frac{\pi}{x}\left(\sum_{k=n}^{\infty}\left|\Delta c_{k}\right|+\left|c_{N}\right|+\left|c_{n}\right|\right) \leq \pi\left(n \frac{4 C \varepsilon}{n}+N\left|c_{N}\right|+n\left|c_{n}\right|\right) \\
& \leq(4 C+2) \pi \varepsilon
\end{aligned}
$$

ahol $\widetilde{D}_{k}(x)=\sum_{j=1}^{k} \sin j x$ a konjugált Dirichlet-magfüggvény (lásd [17, 2. oldal]), melyről ismert, hogy $\left|\widetilde{D}_{k}(x)\right| \leq \pi / x$ bármely $k \geq 1$ és $0<x \leq \pi$ esetén. Végül, az $n_{2}<n \leq v<N$ esetben

$$
|s(n, N ; x)| \leq|s(n, v ; x)|+|s(v+1, N ; x)| \leq(4 C \pi+2 \pi+1) \varepsilon .
$$

Ezzel az (1.6) egyenlőtlenség és így az (i) rész igazolást nyert.

(ii) rész: Tegyük fel, hogy $\left\{c_{k}\right\} \subset \overline{\mathbb{R}}_{+}$és (1.1) egyenletesen konvergens $x$-ben. Legyen $\varepsilon>0$ tetszőleges. Ekkor a Cauchy-féle konvergenciakritérium alkalmazásával kapjuk, hogy létezik olyan $n_{0}$, melyre bármely $n>n_{0}$ és tetszőleges $x$ esetén

$$
|s(n, 2 n ; x)|=\left|\sum_{k=n}^{2 n} c_{k} \sin k x\right| \leq \varepsilon .
$$

Legyen

$$
x(n):=\frac{\pi}{4 n} .
$$

Ekkor tetszőleges $n \leq k \leq 2 n$ esetén

$$
\frac{\pi}{4} \leq k x(n) \leq \frac{\pi}{2}
$$

és így

$$
\sin (k x(n)) \geq \sin \frac{\pi}{4}=\frac{1}{\sqrt{2}}, \quad n \leq k \leq 2 n .
$$

Mivel $b(n) \rightarrow \infty$, ezért létezik olyan $n_{1}$, melyre bármely $n>n_{1}$ esetén $b(n)>n_{0}$. Ekkor az 1.3.2. Lemma, valamint (1.7) és (1.8) következtében bármely $n>n_{2}:=\max \left\{n_{0}, n_{1}\right\}$-re fennáll az

$$
\begin{aligned}
n c_{n} & \leq C \sup _{m \geq b(n)} \sum_{k=m}^{2 m} c_{k}+\sum_{k=n}^{2 n} c_{k} \leq \sqrt{2} C \sup _{m \geq b(n)}(s(m, 2 m ; x(m))+s(n, 2 n ; x(n))) \\
& \leq \sqrt{2}(C+1) \varepsilon
\end{aligned}
$$

egyenlőtlenség, ezzel a tétel második része is bizonyítást nyert.

Az 1.2.4 Állítás bizonyítása. Tegyük fel, hogy $\left\{c_{k}\right\} \in \mathrm{SBVS}_{2} \backslash \mathrm{SBVS}$. Legyen

$$
B_{n}:=\sup _{m \geq n} \sum_{k=m}^{2 m}\left|c_{k}\right| \quad \text { és } \quad S:=\limsup _{n \rightarrow \infty} B_{n}
$$


ahol $B_{n}, S \in[0, \infty]$. Nyilvánvaló, hogy $B_{n}$ nemnövő sorozat. Ezért az $S=\infty$ esetben $B_{n}=\infty$ minden $n$-re, ami viszont ellentmondás, mivel (1.4) teljesül tetszőleges $C, \lambda$ esetén. A második lehetőség az, hogy $0<S<\infty$. Ekkor $\left\{B_{n}\right\}$ korlátos, tehát $S<B_{n}<T$, ez viszont ellentmond a $\left\{c_{k}\right\} \notin$ SBVS feltevésnek, mivel (1.4) fennáll a $C \cdot T / S$ és tetszőleges $\lambda$ konstansokkal, ahol $C$ a $\left\{c_{k}\right\}$-hoz tartozó, (1.5)-beli konstans. Az utolsó $S=0$ esetben $\sum_{k=n}^{2 n}\left|c_{k}\right|$ és $B_{b(n)}$ is 0 -hoz tart, ha $n$ tart a végtelenbe, így az 1.3.2. Lemma felhasználásával megkapjuk (1.2)-t.

\subsection{Formális deriválás és integrálás}

Ebben az alfejezetben a

$$
\sum_{k=1}^{\infty} k^{r} c_{k} \sin k x
$$

sor egyenletes konvergenciáját vizsgáljuk, ahol $r$ egész. Ezen sor $r=0$ esetben az (1.1) szinuszsor, pozitív páros $r$ esetén (1.1) $r$-szeres formális deriváltja, negatív páros $r$ esetén (1.1) $r$-szeres formális integrálja; páratlan $r$ esetén koszinuszsor formális deriváltjáról ill. integráljáról beszélünk, ezen esetet itt most nem tárgyaljuk. Az alfejezet eredményei megtalálhatók [5]-ben.

Könnyen meggondolható, hogy ha $r$ pozitív, létezik olyan $\left\{c_{k}\right\}$ nemnegatív, monoton nemnövő sorozat, melyre $\left\{k^{r} c_{k}\right\}$ nem tartozik a monoton nemnövő sorozatok közé. Ellenben az MVBVS osztály zárt a $k^{r}$-rel való szorzásra ( $r$ egész), mint azt a következő tétel mutatja.

1.4.1. Tétel. $H a\left\{c_{k}\right\}$ sorozat MVBVS-beli, akkor $\left\{d_{k}=k^{r} c_{k}\right\}$ szintén MVBVS-beli tetszöleges rögzített $r$ egész szám esetén.

Bizonyítás. Legyen $\left\{c_{k}\right\} \in$ MVBVS a $C$ és $\lambda$ konstansokkal. Elegendő megmutatnunk, hogy $\left\{d_{k}=k^{r} c_{k}\right\} \in$ MVBVS, ha $r=1$ vagy $r=-1$, hiszen ekkor teljes indukciót alkalmazva minden $r$-re kiterjeszthető az eredmény. Az $r=1$ esetben

$$
\begin{aligned}
\sum_{k=n}^{2 n}\left|\Delta d_{k}\right| & \leq \sum_{k=n}^{2 n}\left(k\left|c_{k}-c_{k+1}\right|+\left|c_{k+1}\right|\right) \leq 2 C \sum_{k=[n / \lambda]}^{[\lambda n]}\left|c_{k}\right|+\frac{1}{n} \sum_{k=n+1}^{2 n+1} k\left|c_{k}\right| \\
& \leq \frac{4 C \lambda}{n} \sum_{k=[n / \lambda]}^{[\lambda n]} k\left|c_{k}\right|+\frac{1}{n} \sum_{k=n+1}^{2 n+1} k\left|c_{k}\right| \leq \frac{4 C \lambda+1}{n} \sum_{k=[n / \lambda]}^{[\lambda n]}\left|d_{k}\right|,
\end{aligned}
$$

míg $r=-1$-re

$$
\sum_{k=n}^{2 n}\left|\Delta d_{k}\right| \leq \sum_{k=n}^{2 n}\left(\frac{1}{k+1}\left|c_{k}-c_{k+1}\right|+\frac{1}{k(k+1)}\left|c_{k+1}\right|\right)
$$




$$
\leq \frac{C}{n^{2}} \sum_{k=[n / \lambda]}^{[\lambda n]}\left|c_{k}\right|+\frac{1}{n} \sum_{k=n+1}^{2 n+1} \frac{1}{k}\left|c_{k}\right| \leq \frac{C \lambda+1}{n} \sum_{k=[n / \lambda]}^{[\lambda n]}\left|d_{k}\right| .
$$

Tehát a tekintett $r$-ek esetén $\left\{d_{k}\right\}$ teljesíti az (1.3) feltételt, így mindkét esetben $\left\{d_{k}\right\} \in$ MVBVS.

Az előbbi tétel és az 1.1.2. Tételt összegezve a következőt kapjuk:

1.4.2. Következmény. Legyen $\left\{c_{k}\right\} \in$ MVBVS és $r$ páros szám.

(i) Ha $k^{r+1} c_{k} \rightarrow 0$, akkor (1.9) egyenletesen konvergens $x$-ben.

(ii) Megfordítva, ha $\left\{c_{k}\right\} \subset \overline{\mathbb{R}}_{+}$és (1.9) egyenletesen konvergens $x$-ben, akkor $k^{r+1} c_{k} \rightarrow 0$.

Az SBVS osztályra az 1.4.1. Tétel fele igaz.

1.4.3. Tétel. $H a\left\{c_{k}\right\}$ sorozat SBVS-beli, akkor $\left\{d_{k}=k^{r} c_{k}\right\}$ szintén SBVS-beli tetszőleges rögzített r pozitiv egész szám esetén.

Bizonyítás. Elegendő az $r=1$ esettel foglalkoznunk, ekkor $\left\{d_{k}=k^{r} c_{k}\right\} \in \mathrm{SBVS}$, hiszen

$$
\begin{aligned}
\sum_{k=n}^{2 n}\left|\Delta d_{k}\right| & \leq \sum_{k=n}^{2 n}\left(k\left|c_{k}-c_{k+1}\right|+\left|c_{k+1}\right|\right) \leq 2 C \sup _{m \geq[n / \lambda]]} \sum_{k=m}^{2 m}\left|c_{k}\right|+\frac{1}{n} \sum_{k=n+1}^{2 n+1} k\left|c_{k}\right| \\
& \leq \frac{4 C \lambda+1}{n} \sup _{m \geq[n / \lambda]} \sum_{k=m}^{2 m}\left|d_{k}\right| .
\end{aligned}
$$

Az iménti tétel és az 1.2.2. Tétel összevetéséből adódik

1.4.4. Következmény. $H a\left\{c_{k}\right\} \in \mathrm{SBVS}$ és $r$ pozitív páros szám, akkor az 1.4.2. Következmény (i) és (ii) állításai fennállnak.

Meggondolható, hogy $\mathrm{SBVS}_{2}$ sem pozitív, sem negatív $r$ esetén nem zárt a $k^{r}$-rel való szorzásra. 


\section{2. fejezet}

\section{Kettős szinuszsorok}

\subsection{A reguláris konvergencia}

Legyen $\left\{c_{j k}\right\}_{j, k=1}^{\infty}$ komplex számok kettős sorozata, röviden $\left\{c_{j k}\right\} \subset \mathbb{C}$. Tekintsük a

$$
\sum_{j=1}^{\infty} \sum_{k=1}^{\infty} c_{j k} \sin j x \sin k y
$$

kettős szinuszsort. Ezen kettős sor egyenletes, reguláris konvergenciáját fogjuk vizsgálni $(x, y)$-ban. Mivel (2.1) minden tagja $x$-ben ill. $y$-ban is $2 \pi$ szerint periodikus páratlan függvény, ezért az egyenletes konvergencia vizsgálatakor elegendő az $(x, y) \in$ $[0, \pi] \times[0, \pi]$ pontpárokkal foglalkoznunk. A $\left\{c_{j k}\right\}$ jelölés a fejezet során mindvégig az 1,1 indexű tagtól indul, viszont szükség szerint $c_{0 k}=c_{j 0}=0$.

A $\sum_{j=1}^{\infty} \sum_{k=1}^{\infty} z_{j k}$ kettős sor regulárisan konvergens, ha a

$$
\sum_{j=1}^{m} \sum_{k=1}^{n} z_{j k}
$$

téglalap alakú összegek véges számhoz konvergálnak, amikor $m$ és $n$ egymástól függetlenül a végtelenbe tart, továbbá a

$$
\sum_{j=1}^{\infty} z_{j n}, \quad n=1,2, \ldots
$$

úgynevezett "sorösszegek", valamint a

$$
\sum_{k=1}^{\infty} z_{m k}, \quad m=1,2, \ldots
$$

"oszlopösszegek" is konvergensek. Amennyiben a sor- ill.oszlopösszegek konvergenciáját nem követeljük meg, csak a téglalap alakú összegek konvergenciáját, akkor Pring- 
sheim értelemben vett konvergenciáról beszélünk. Amely kettős sor reguláris értelemben konvergens, az Pringsheim értelemben is az, viszont a fordított irányú érvelés nem igaz. A reguláris konvergencia definíciójával ekvivalens (lásd [9]) a következő: $\sum_{j=1}^{\infty} \sum_{k=1}^{\infty} z_{j k}$ regulárisan konvergens, ha bármely $\varepsilon>0$-hoz létezik olyan pozitív $m_{0}=$ $m_{0}(\varepsilon)$ küszöbszám, melyre

$$
\left|\sum_{j=m}^{M} \sum_{k=n}^{N} z_{j k}\right|<\varepsilon
$$

fennáll minden olyan $m, n, M, N$ számokra, melyekre $m+n>m_{0}, 1 \leq m \leq M, 1 \leq n \leq N$.

Az egyváltozós Chaundy-Jolliffe-tételhez hasonlóan, a kettős szinuszsorok esetében is ismert egy tétel akkor, amikor az együtthatók nemnegatív, monoton nemnövő kettős sorozatot alkotnak. A nemnegatív valós $\left\{c_{j k}\right\}$ kettős sorozat monoton nemnövő, ha

$$
\Delta_{10} c_{j k} \geq 0, \Delta_{01} c_{j k} \geq 0, \Delta_{11} c_{j k} \geq 0, \quad j, k=1,2, \ldots,
$$

ahol

$$
\begin{aligned}
& \Delta_{10} c_{j k}:=c_{j k}-c_{j+1, k}, \quad \Delta_{01} c_{j k}:=c_{j k}-c_{j, k+1}, \\
& \Delta_{11} c_{j k}:=\Delta_{10}\left(\Delta_{01} c_{j k}\right)=\Delta_{01}\left(\Delta_{10} c_{j k}\right)=c_{j k}-c_{j+1, k}-c_{j, k+1}+c_{j+1, k+1} .
\end{aligned}
$$

Žak és Šneider tétele a következő:

2.1.1. Tétel. [14] $H a\left\{c_{j k}\right\} \subset \mathbb{R}_{+}$monoton nemnövö, akkor (2.1) reguláris konvergenciája egyenletes $(x, y)$-ban akkor és csak akkor, ha

$$
j k c_{j k} \rightarrow 0, \quad \text { ha } j+k \rightarrow \infty \text {. }
$$

\subsection{Az NBVDS és MVBVDS osztályok}

A monotonitás általánosításaképp először definiáljuk az NBVS osztály kétdimenziós megfelelőjét.

Definíció. A $\left\{c_{j k}\right\} \subset \mathbb{C}$ kettős sorozatot Non-onesided Bounded Variation Double Sequence-nek nevezzük, röviden $\left\{c_{j k}\right\} \in$ NBVDS, ha létezik csak a $\left\{c_{j k}\right\}$-tól függő $C$ konstans, melyre

$$
\begin{aligned}
& \sum_{j=m}^{2 m-1}\left|\Delta_{10} c_{j n}\right| \leq C\left(\left|c_{m n}\right|+\left|c_{2 m, n}\right|\right), \\
& \sum_{k=n}^{2 n-1}\left|\Delta_{01} c_{m k}\right| \leq C\left(\left|c_{m n}\right|+\left|c_{m, 2 n}\right|\right),
\end{aligned}
$$




$$
\sum_{j=m}^{2 m-1} \sum_{k=n}^{2 n-1}\left|\Delta_{11} c_{j k}\right| \leq C\left(\left|c_{m n}\right|+\left|c_{2 m, n}\right|+\left|c_{m, 2 n}\right|+\left|c_{2 m, 2 n}\right|\right) .
$$

Könnyen meggondolható, hogy bármely nemnegatív, monoton nemnövő kettős sorozat NBVDS-beli.

Az MVBVS osztály kétdimenziós megfelelője a következő.

Definíció. A $\left\{c_{j k}\right\} \subset \mathbb{C}$ kettős sorozatot MVBVDS-belinek (Mean Value Bounded Variation Double Sequences) nevezzük, ha léteznek $C$ és $\lambda \geq 2$ konstans számok, melyek csak $\left\{c_{j k}\right\}$-tól függnek, és amelyekre

$$
\begin{aligned}
\sum_{j=m}^{2 m-1}\left|\Delta_{10} c_{j n}\right| & \leq \frac{C}{m} \sum_{j=[m / \lambda]}^{[\lambda m]}\left|c_{j n}\right|, \quad m \geq \lambda, n \geq 1, \\
\sum_{k=n}^{2 n-1}\left|\Delta_{01} c_{m k}\right| & \leq \frac{C}{n} \sum_{k=[n / \lambda]}^{[\lambda n]}\left|c_{m k}\right|, \quad m \geq 1, n \geq \lambda, \\
\sum_{j=m}^{2 m-1} \sum_{k=n}^{2 n-1}\left|\Delta_{11} c_{j k}\right| & \leq \frac{C}{m n} \sum_{j=[m / \lambda]}^{[\lambda m]} \sum_{k=[n / \lambda]}^{[\lambda n]}\left|c_{j k}\right|, \quad m, n \geq \lambda .
\end{aligned}
$$

Megmutatjuk, hogy az MVBVDS és az NBVDS osztályok között valódi tartalmazási reláció áll fenn.

2.2.1. Tétel. [7] MVBVDS $\supsetneqq$ NBVDS.

A 2.1.1. Tétel általánosítása a következő:

2.2.2. Tétel. [7] Legyen $\left\{c_{j k}\right\} \subset \mathbb{C}$ kettős sorozat MVBVDS-beli.

(i) Ha (2.2) teljesül, akkor (2.1) reguláris konvergenciája egyenletes ( $x, y)$-ban.

(ii) Megfordítva, ha $\left\{c_{j k}\right\} \subset \overline{\mathbb{R}}_{+}$és (2.1) reguláris konvergenciája egyenletes $(x, y)$-ban, akkor (2.2) fennáll.

Speciálisan, ha $\left\{c_{j k}\right\} \subset \overline{\mathbb{R}}_{+}$kettős sorozat MVBVDS-beli, akkor (2.2) szükséges és elegendő feltétele annak, hogy (2.1) reguláris konvergenciája egyenletes legyen $(x, y)$-ban.

\subsection{Segédállítások}

A 2.2.1. és 2.2.2. Tételek bizonyítása előtt belátunk két lemmát, melyek az MVBVDS osztályba tartozó sorozatok fontos tulajdonságait mutatják meg.

2.3.1. Lemma. [7] Tegyük fel, hogy $\left\{c_{j k}\right\} \subset \mathbb{C}$ teljesíti a (2.2) és (2.8) feltételeket. Ekkor

$$
m n \sum_{j=m}^{\infty} \sum_{k=n}^{\infty}\left|\Delta_{11} c_{j k}\right| \rightarrow 0, \quad \text { ha } m+n \rightarrow \infty \text { és } m, n \geq \lambda .
$$


Továbbá,

$$
m n \sum_{j=m}^{\infty} \sup _{k \geq n}\left|\Delta_{10} c_{j k}\right| \rightarrow 0, \quad m n \sum_{k=n}^{\infty} \sup _{j \geq m}\left|\Delta_{01} c_{j k}\right| \rightarrow 0,
$$

ha $m+n \rightarrow \infty$ és $m, n \geq \lambda$.

Bizonyítás. Legyen $\varepsilon>0$ tetszőleges. Ekkor (2.2) szerint létezik $m_{0}=m_{0}(\varepsilon)$ küszöbszám, melyre $j k\left|c_{j k}\right| \leq \varepsilon$ bármely $j+k>m_{0}$ esetén. Így (2.8)-at felhasználva kapjuk, hogy bármely $m+n>m_{0}$ és $m, n \geq \lambda$ esetén igaz a következő:

$$
\begin{aligned}
\sum_{j=m}^{\infty} \sum_{k=n}^{\infty}\left|\Delta_{11} c_{j k}\right| & =\sum_{r=0}^{\infty} \sum_{s=0}^{\infty} \sum_{j=2^{r} m}^{2^{r+1} m-1} \sum_{k=2^{s} n}^{n-1}\left|\Delta_{11} c_{j k}\right| \\
& \leq C \sum_{r=0}^{\infty} \sum_{s=0}^{\infty} \frac{1}{2^{r+s} m n} \sum_{j=\left[2^{r} m / \lambda\right]}^{\left[\lambda 2^{r} m\right]} \sum_{k=\left[2^{s} n / \lambda\right]}^{\left[\lambda 2^{s} n\right]}\left|c_{j k}\right| \\
& \leq \frac{C \varepsilon}{m n} \sum_{r=0}^{\infty} \sum_{s=0}^{\infty} \frac{1}{2^{r+s}} \sum_{j=\left[2^{r} m / \lambda\right]}^{\left[\lambda 2^{r} m\right]} \sum_{k=\left[2^{s} n / \lambda\right]}^{\left[\lambda 2^{s} n\right]} \frac{1}{j k} \\
& \leq \frac{4 \lambda^{4} C \varepsilon}{m n} \sum_{r=0}^{\infty} \frac{1}{2^{r}} \sum_{s=0}^{\infty} \frac{1}{2^{s}}=\frac{16 \lambda^{4} C \varepsilon}{m n},
\end{aligned}
$$

ami igazolja (2.9)-et. (2.10) első része következik a

$$
\sum_{j=m}^{\infty} \sup _{k \geq n}\left|\Delta_{10} c_{j k}\right| \leq \sum_{j=m}^{\infty} \sup _{k \geq n} \sum_{v=k}^{\infty}\left|\Delta_{11} c_{j v}\right| \leq \sum_{j=m}^{\infty} \sum_{k=n}^{\infty}\left|\Delta_{11} c_{j k}\right|
$$

egyenlőtlenségből, a második része pedig hasonló módon belátható.

2.3.2. Lemma. [7] Legyen $\left\{c_{j k}\right\} \subset \overline{\mathbb{R}}_{+}$MVBVDS-beli a C és $\lambda$ konstansokkal. Ekkor

$$
m n c_{m n} \leq(3 C+2) \sum_{j=[m / \lambda]}^{[\lambda m]} \sum_{k=[n / \lambda]}^{[\lambda n]} c_{j k}, \quad \text { ha } m, n \geq \lambda .
$$

Bizonyítás. Legyen $m, n \geq \lambda$ tetszőleges. Ekkor (2.6) szerint bármely $m+1 \leq \mu \leq 2 m$ és $v$ egész számokra

$$
c_{m v} \leq \sum_{j=m}^{\mu-1}\left|\Delta_{10} c_{j v}\right|+c_{\mu v} \leq \sum_{j=m}^{2 m-1}\left|\Delta_{10} c_{j v}\right|+c_{\mu v} \leq \frac{C}{m} \sum_{j=[m / \lambda]}^{[\lambda m]} c_{j v}+c_{\mu v} .
$$

Hasonlóan kapjuk, (2.7)-et alkalmazva, hogy bármely $\mu$ és $n+1 \leq v \leq 2 n$-re

$$
c_{\mu n} \leq \frac{C}{n} \sum_{k=[n / \lambda]}^{[\lambda n]} c_{\mu k}+c_{\mu v} .
$$

Továbbá, bármely $m+1 \leq \mu \leq 2 m, n+1 \leq v \leq 2 n$ egész számokra fennáll a

$$
c_{m n}=\sum_{j=m}^{\mu-1} \sum_{k=n}^{v-1} \Delta_{11} c_{j k}+c_{m v}+c_{\mu n}-c_{\mu v} \leq \sum_{j=m}^{\mu-1} \sum_{k=n}^{v-1}\left|\Delta_{11} c_{j k}\right|+c_{m v}+c_{\mu n}
$$




$$
\leq \sum_{j=m}^{2 m-1} \sum_{k=n}^{2 n-1}\left|\Delta_{11} c_{j k}\right|+c_{m v}+c_{\mu n} \leq \frac{C}{m n} \sum_{j=[m / \lambda]}^{[\lambda m]} \sum_{k=[n / \lambda]}^{[\lambda n]} c_{j k}+c_{m v}+c_{\mu n}
$$

egyenlőtlenség. Összegezve a legutóbb kapott egyenlőtlenséget a $\mu$ és $v$ megengedett értékeire,

$$
\begin{aligned}
m n c_{m n} \leq & C \sum_{j=[m / \lambda]}^{[\lambda m]} \sum_{k=[n / \lambda]}^{[\lambda n]} c_{j k}+m \sum_{v=n+1}^{2 n} c_{m v}+n \sum_{\mu=m+1}^{2 m} c_{\mu n} \\
\leq & C \sum_{j=[m / \lambda]}^{[\lambda m]} \sum_{k=[n / \lambda]}^{[\lambda n]} c_{j k}+C \sum_{v=n+1}^{2 n} \sum_{j=[m / \lambda]}^{[\lambda m]} c_{j v}+C \sum_{\mu=m+1}^{2 m} \sum_{k=[n / \lambda]}^{[\lambda n]} c_{\mu k} \\
& +2 \sum_{\mu=m+1}^{2 m} \sum_{v=n+1}^{2 n} c_{\mu v} \leq(3 C+2) \sum_{j=[m / \lambda]}^{[\lambda m]} \sum_{k=[n / \lambda]}^{[\lambda n]} c_{j k} .
\end{aligned}
$$

Ezzel beláttuk (2.11)-et.

\subsection{A 2.2.1. és 2.2.2. Tételek bizonyítása}

A 2.2.1. Tétel bizonyítása. Megmutatjuk, hogy MVBVDS $\supseteq$ NBVDS. Ehhez tekintsünk egy tetszőleges $\left\{c_{j k}\right\} \in$ NBVDS-beli sorozatot a $C$ konstanssal. (2.3) és (2.4) szerint $\left\{c_{j k}\right\}_{j=1}^{\infty} \in$ NBVS $\subset$ MVBVS és $\left\{c_{j k}\right\}_{k=1}^{\infty} \in$ NBVS $\subset$ MVBVS, ezért a (2.6) és (2.7) egyenlőtlenségek fennállnak $C$ helyett $6 C$-vel és $\lambda=3$-mal (lásd [7]). Tehát már csak (2.8)-at kell igazolnunk. Legyen $m, n \geq 6$. Ekkor (2.3)-at alkalmazva a $\mu, v$ párokra, ahol

$$
m-[m / 6] \leq \mu \leq m+[m / 6], \quad n-[n / 6] \leq v \leq n+[n / 6],
$$

kapjuk, hogy

$$
\begin{aligned}
\sum_{\mu=m-[m / 6]}^{m+[m / 6]} & \sum_{v=n-[n / 6]}^{n+[n / 6]} \sum_{j=\mu}^{2 \mu-1} \sum_{k=v}^{2 v-1}\left|\Delta_{11} c_{j k}\right| \\
& \leq C \sum_{j=m-[m / 6]}^{m+[m / 6]} \sum_{k=n-[n / 6]}^{n+[n / 6]}\left(\left|c_{j k}\right|+\left|c_{2 j, k}\right|+\left|c_{j, 2 k}\right|+\left|c_{2 j, 2 k}\right|\right) .
\end{aligned}
$$

Az egyenlőtlenség bal oldalán $\left|\Delta_{11} c_{j k}\right|$ legalább

$$
\left(\left[\frac{m}{6}\right]+1\right)\left(\left[\frac{n}{6}\right]+1\right) \geq \frac{m n}{36} \text {-szor }
$$

szerepel minden $m \leq j \leq 2 m-1, n \leq k \leq 2 n-1$ indexpárra, valamint a jobb oldalon $\left|c_{j k}\right|$ lehetséges indexeire

$$
\min j \geq m-\left[\frac{m}{6}\right] \geq \frac{m}{3}, \quad \min k \geq n-\left[\frac{n}{6}\right] \geq \frac{n}{3},
$$


illetve $\left|c_{2 j, 2 k}\right|$ lehetséges indexeire

$$
\max j \leq 2\left(m+\left[\frac{m}{6}\right]\right) \leq 3 m, \quad \max k \leq 2\left(n+\left[\frac{n}{6}\right]\right) \leq 3 n,
$$

továbbá egyetlen indexpár sem szerepel egynél többször, hiszen

$$
\max j \leq m+\left[\frac{m}{6}\right]<2\left(m-\left[\frac{m}{6}\right]\right) \leq \min 2 j,
$$

és hasonlóan $k$-ra. Tehát

$$
\frac{m n}{36} \sum_{j=m}^{2 m-1} \sum_{k=n}^{2 n-1}\left|\Delta_{11} c_{j k}\right| \leq C \sum_{j=[m / 3]}^{3 m} \sum_{k=[n / 3]}^{3 n}\left|c_{j k}\right|,
$$

így $\left\{c_{j k}\right\} \in$ MVBVDS a 36C és $\lambda=3$ konstansokkal.

Ezek után példát mutatunk olyan sorozatra, mely MVBVDS $\backslash$ NBVDS-beli. Vegyünk egy olyan $\left\{c_{k}\right\}$ sorozatot, mely MVBVS-beli a $C$ és $\lambda$ konstansokkal, de nem NBVS-beli, és legyen $c_{j k}:=c_{j} c_{k}$. Ekkor (2.6) teljesül, hiszen

$$
\sum_{j=m}^{2 m-1}\left|\Delta_{10} c_{j n}\right|=\left|c_{n}\right| \sum_{j=m}^{2 m-1}\left|\Delta c_{j}\right| \leq\left|c_{n}\right| \frac{C}{m} \sum_{j=[m / \lambda]}^{[\lambda m]}\left|c_{j}\right|=\frac{C}{m} \sum_{j=[m / \lambda]}^{[\lambda m]}\left|c_{j n}\right|,
$$

és (2.7) hasonlóan igazolható. Továbbá,

$$
\begin{aligned}
\sum_{j=m}^{2 m-1} \sum_{k=n}^{2 n-1}\left|\Delta_{11} c_{j k}\right| & =\sum_{j=m}^{2 m-1}\left|\Delta c_{j}\right| \sum_{k=n}^{2 n-1}\left|\Delta c_{k}\right| \leq \frac{C}{m} \sum_{j=[m / \lambda]}^{[\lambda m]}\left|c_{j}\right| \frac{C}{n} \sum_{k=[n / \lambda]}^{[\lambda n]}\left|c_{k}\right| \\
& =\frac{C^{2}}{m n} \sum_{j=[m / \lambda]}^{[\lambda m]} \sum_{k=[n / \lambda]}^{[\lambda n]}\left|c_{j k}\right|
\end{aligned}
$$

tehát $\left\{c_{j k}\right\} \in$ MVBVDS a $C^{2}$ és $\lambda$ konstansokkal. Ellenben, mivel $\left\{c_{k}\right\} \notin$ NBVS, ezért $c_{j k}$ definíciója miatt sem (2.3), sem (2.4) nem teljesül.

A 2.2.2. Tétel bizonyítása. Legyen $\left\{c_{j k}\right\} \subset \mathbb{C}$ MVBVDS-beli a $C$ és $\lambda$ konstansokkal.

(i) rész: Tegyük fel, hogy (2.2) fennáll. A (2.6) és (2.7) feltételek teljesülése miatt $\left\{c_{j n}\right\}_{j=1}^{\infty} \in$ MVBVS bármely $n$-re és $\left\{c_{m k}\right\}_{k=1}^{\infty} \in$ MVBVS bármely $m$-re, ezért az 1.1.2. Tétel alkalmazható, így a

$$
\sum_{j=1}^{\infty} c_{j n} \sin j x, \quad n=1,2, \ldots ; \quad \sum_{k=1}^{\infty} c_{m k} \sin k y, \quad m=1,2, \ldots
$$

sor- ill. oszlopösszegek egyenletesen konvergensek $x$-ben ill. $y$-ban, ezáltal $(x, y)$-ban is. Az elkövetkezőkben az $s(m, M ; n, N ; x, y)$ jelölést használjuk a téglalap alakú összegek rövidítésére:

$$
s(m, M ; n, N ; x, y):=\sum_{j=m}^{M} \sum_{k=n}^{N} c_{j k} \sin j x \sin k y .
$$


Mivel $s(m, M ; n, N ; 0, y)=s(m, M ; n, N ; x, 0)=0$, ezért elegendő az $(x, y) \in(0, \pi) \times(0, \pi)$ pontpárokkal foglalkoznunk. Legyen

$$
\mu(x):=\left[\frac{1}{x}\right] \quad \text { és } \quad v(x):=\left[\frac{1}{y}\right] .
$$

Legyen $\varepsilon>0$ tetszőleges. Ekkor (2.2)-ből következik, hogy létezik olyan $m_{1}=m_{1}(\varepsilon)>\lambda$, melyre

$$
m n\left|c_{m n}\right| \leq \varepsilon \quad \text { bármely } m, n>m_{1} \text { esetén. }
$$

Továbbá, 2.3.1. Lemma szerint létezik $m_{2}=m_{2}(\varepsilon)>\lambda$, melyre

$$
m n \sum_{j=m}^{\infty} \sum_{k=n}^{\infty}\left|\Delta_{11} c_{j k}\right| \leq \varepsilon, \quad m n \sum_{j=m}^{\infty} \sup _{k \geq n}\left|\Delta_{10} c_{j k}\right| \leq \varepsilon, \quad m n \sum_{k=n}^{\infty} \sup _{j \geq m}\left|\Delta_{01} c_{j k}\right| \leq \varepsilon
$$

bármely $m, n>m_{2}$ esetén. Legyen $m_{0}:=\max \left\{m_{1}, m_{2}\right\}$.

$\mathrm{Az}|s(m, M ; n, N ; x, y)|$ téglalap alakú összegek abszolút értékének becslésekor négy alapesetet különböztetünk meg, az $m, M$ és a $\mu$ ill. az $n, N$ és a $v$ viszonya alapján.

(a) eset: $m_{0}<m \leq M \leq \mu$ és $m_{0}<n \leq N \leq v$. Ekkor mivel $0<j x<1$ és $0<k y<1$, ezért

$$
|s(m, M ; n, N ; x, y)| \leq x y \sum_{j=m}^{M} \sum_{k=n}^{N}\left|c_{j k}\right| \leq \frac{1}{\mu \nu} \sum_{j=m}^{\mu} \sum_{k=n}^{v} \varepsilon \leq \varepsilon .
$$

(b) eset: $\max \left\{m_{0}, \mu\right\}<m \leq M$ és $m_{0}<n \leq N \leq v$. Ekkor a következőképpen becsülünk.

$$
\begin{aligned}
|s(m, M ; n, N ; x, y)| & =\sum_{k=n}^{N} \sin k y\left|\sum_{j=m}^{M} c_{j k} \sin j x\right| \leq y \sum_{k=n}^{N} k\left|\sum_{j=m}^{M} c_{j k} \sin j x\right| \\
& \leq \frac{1}{v} \sum_{k=n}^{v} k\left|\sum_{j=m}^{M} c_{j k} \sin j x\right| .
\end{aligned}
$$

Ezután az utolsó összeget Abel-átrendezéssel átalakítva, majd a konjugált Dirichletmagfüggvény ismert becslését alkalmazva - hasonlóan az 1.2.2. Tétel (i) részének bizonyításához - kapjuk, hogy

$$
\begin{aligned}
\left|\sum_{j=m}^{M} c_{j k} \sin j x\right| & \leq \sum_{j=m}^{M-1}\left|\Delta_{10} c_{j k}\right|\left|\widetilde{D}_{j}(x)\right|+\left|c_{M k}\right|\left|\widetilde{D}_{M}(x)\right|+\left|c_{m k}\right|\left|\widetilde{D}_{m-1}(x)\right| \\
& \leq \frac{\pi}{x} \sum_{j=m}^{M-1}\left|\Delta_{10} c_{j k}\right|+\left|c_{M k}\right|+\left|c_{m k}\right| .
\end{aligned}
$$

Így az eredeti becslést folytatva

$$
|s(m, M ; n, N ; x, y)| \leq \frac{\pi}{x v} \sum_{k=n}^{v} k\left(\sum_{j=m}^{M-1}\left|\Delta_{10} c_{j k}\right|+\left|c_{M k}\right|+\left|c_{m k}\right|\right)
$$




$$
\leq \frac{\pi}{v} \sum_{k=n}^{v}\left(m k \sum_{j=m}^{\infty}\left|\Delta_{10} c_{j k}\right|+M k\left|c_{M k}\right|+m k\left|c_{m k}\right|\right),
$$

az $m_{0}$ definícióját felhasználva pedig

$$
|s(m, M ; n, N ; x, y)| \leq \frac{\pi}{v} \sum_{k=n}^{v} 3 \varepsilon \leq 3 \pi \varepsilon .
$$

(c) eset: $m_{0}<m \leq M \leq \mu$ és $\max \left\{m_{0}, v\right\}<n \leq N$. Ezen eset (b) szimmetrikus párja, és ahhoz hasonló érveléssel adódik, hogy

$$
|s(m, M ; n, N ; x, y)| \leq 3 \pi \varepsilon .
$$

(d) eset: $\max \left\{m_{0}, \mu\right\}<m \leq M$ és $\max \left\{m_{0}, v\right\}<n \leq N$. Ekkor kettős Abel-átrendezéssel adódik, hogy

$$
\begin{aligned}
s(m, M ; n, N ; x, y)= & \sum_{j=m}^{M-1} \sum_{k=n}^{N-1} \widetilde{D}_{j}(x) \widetilde{D}_{k}(y) \Delta_{11} c_{j k} \\
& +\sum_{j=m}^{M-1} \widetilde{D}_{j}(x) \widetilde{D}_{N}(y) \Delta_{10} c_{j N}-\sum_{j=m}^{M-1} \widetilde{D}_{j}(x) \widetilde{D}_{n-1}(y) \Delta_{10} c_{j n} \\
& +\sum_{k=n}^{N-1} \widetilde{D}_{M}(x) \widetilde{D}_{k}(y) \Delta_{01} c_{M k}-\sum_{k=n}^{N-1} \widetilde{D}_{m-1}(x) \widetilde{D}_{k}(y) \Delta_{01} c_{m k} \\
& +c_{M N} \widetilde{D}_{M}(x) \widetilde{D}_{N}(y)-c_{M n} \widetilde{D}_{M}(x) \widetilde{D}_{n-1}(y) \\
& -c_{m N} \widetilde{D}_{m-1}(x) \widetilde{D}_{N}(y)+c_{m n} \widetilde{D}_{m-1}(x) \widetilde{D}_{n-1}(y)
\end{aligned}
$$

így

$$
\begin{aligned}
|s(m, M ; n, N ; x, y)| \leq \frac{\pi^{2}}{x y}( & \sum_{j=m}^{M-1} \sum_{k=n}^{N-1}\left|\Delta_{11} c_{j k}\right|+\sum_{j=m}^{M-1}\left|\Delta_{10} c_{j N}\right|+\sum_{j=m}^{M-1}\left|\Delta_{10} c_{j n}\right| \\
& +\sum_{k=n}^{N-1}\left|\Delta_{01} c_{M k}\right|+\sum_{k=n}^{N-1}\left|\Delta_{01} c_{m k}\right| \\
& \left.+\left|c_{M N}\right|+\left|c_{M n}\right|+\left|c_{m N}\right|+\left|c_{m n}\right|\right) \\
\leq \pi^{2} m n\left(\sum_{j=m}^{\infty} \sum_{k=n}^{\infty}\left|\Delta_{11} c_{j k}\right|+2 \sum_{j=m}^{\infty} \sup _{k \geq n}\left|\Delta_{10} c_{j k}\right|\right. & \\
& \left.+2 \sum_{k=n}^{\infty} \sup _{j \geq m}\left|\Delta_{01} c_{j k}\right|+4 \sup _{j \geq m, k \geq n}\left|c_{j k}\right|\right) .
\end{aligned}
$$

Végül, az $m_{0}$ definíciója alapján

$$
|s(m, M ; n, N ; x, y)| \leq 9 \pi^{2} \varepsilon .
$$


Az alapesetekben kapott becslések alapján belátjuk, hogy tetszőleges $M \geq m>m_{0}$, $N \geq n>m_{0}$ és $(x, y)$ esetén

$$
|s(m, M ; n, N ; x, y)| \leq\left(9 \pi^{2}+6 \pi+1\right) \varepsilon .
$$

Legyen $(x, y)$ tetszőleges, de rögzített számpár, ekkor $\mu$ és $v$ is rögzített szám, melyek $m_{0}$-hoz való viszonya ismeretlen. Kilenc esetet tárgyalunk, ami által az összes szükséges $m, M, n, N$ számnégyest megvizsgáljuk. $\mu$ és $v$ értékétől függően előfordulhat, hogy egyes esetekben nincsen olyan $m, M, n, N$ számnégyes, mely teljesíti az adott eset feltételeit; ezzel együtt vizsgálatunk teljeskörű. Megjegyzendő, hogy az 5. eset tetszőleges $\mu, v$ pár esetén megvalósul.

1. eset: $m_{0}<m \leq M \leq \mu$ és $m_{0}<n \leq N \leq v$. Ez megegyezik (a) alapesettel, ekkor tehát $|s(m, M ; n, N ; x, y)| \leq \varepsilon$.

2. eset: $\max \left\{m_{0}, \mu\right\}<m \leq M$ és $m_{0}<n \leq N \leq v$. Ezt az esetet tárgyaltuk (b)-ben. Ekkor $|s(m, M ; n, N ; x, y)| \leq 3 \pi \varepsilon$.

3. eset: $m_{0}<m \leq \mu<M$ és $m_{0}<n \leq N \leq v$. Ekkor az (a) és (b) alapesetekbeli becsléseket felhasználva kapjuk, hogy

$$
|s(m, M ; n, N ; x, y)| \leq|s(m, \mu ; n, N ; x, y)|+|s(\mu+1, M ; n, N ; x, y)| \leq(3 \pi+1) \varepsilon .
$$

4. eset: $m_{0}<m \leq M \leq \mu$ és $\max \left\{m_{0}, v\right\}<n \leq N$. Ezt az esetet tárgyaltuk (c)-ben (ez a 2. eset szimmetrikus párja). Ekkor $|s(m, M ; n, N ; x, y)| \leq 3 \pi \varepsilon$.

5. eset: $\max \left\{m_{0}, \mu\right\}<m \leq M$ és $\max \left\{m_{0}, v\right\}<n \leq N$. Ez megegyezik (d) alapesettel, tehát $|s(m, M ; n, N ; x, y)| \leq 9 \pi^{2} \varepsilon$.

6. eset: $m_{0}<m \leq \mu<M$ és $\max \left\{m_{0}, v\right\}<n \leq N$. A (c) és (d) alapesetekbeli becsléseket felhasználva kapjuk, hogy

$$
|s(m, M ; n, N ; x, y)| \leq|s(m, \mu ; n, N ; x, y)|+|s(\mu+1, M ; n, N ; x, y)| \leq\left(9 \pi^{2}+3 \pi\right) \varepsilon .
$$

7. eset: $m_{0}<m \leq M \leq \mu$ és $m_{0}<n \leq v<N$. Ez a 3. eset szimmetrikus párja, az (a) és (c) alapesetek figyelembe vételével

$$
|s(m, M ; n, N ; x, y)| \leq|s(m, M ; n, v ; x, y)|+|s(m, M ; v+1, N ; x, y)| \leq(3 \pi+1) \varepsilon .
$$

8. eset: $\max \left\{m_{0}, \mu\right\}<m \leq M$ és $m_{0}<n \leq v<N$. Ez a 6. eset szimmetrikus párja, a (b) és (d) alapeseteket felhasználva kapjuk, hogy

$$
|s(m, M ; n, N ; x, y)| \leq|s(m, M ; n, v ; x, y)|+|s(m, M ; v+1, N ; x, y)| \leq\left(9 \pi^{2}+3 \pi\right) \varepsilon .
$$

9. eset: $m_{0}<m \leq \mu<M$ és $m_{0}<n \leq v<N$. Az (a)-(d) alapeseteket összegezve adódik, hogy ekkor

$$
|s(m, M ; n, N ; x, y)| \leq|s(m, \mu ; n, v ; x, y)|+|s(\mu+1, M ; n, v ; x, y)|
$$




$$
\begin{aligned}
& +|s(m, \mu ; v+1, N ; x, y)|+|s(\mu+1, M ; v+1, N ; x, y)| \\
\leq & \left(9 \pi^{2}+6 \pi+1\right) \varepsilon .
\end{aligned}
$$

Ezzel beláttuk (2.13)-at. Ahhoz, hogy igazoljuk (2.1) egyenletes, reguláris konvergenciáját, szükség van még annak bebizonyítására, hogy $|s(m, M ; n, N ; x, y)|$ elég kicsi, ha $m+n$ elég nagy. Ehhez rögzítsünk egy tetszőleges $\eta>0$ számot. Válasszuk a (2.13)-beli $\varepsilon$-t a következőképpen:

$$
\varepsilon:=\frac{\eta}{2\left(9 \pi^{2}+6 \pi+1\right)}
$$

Tudjuk, hogy a (2.12)-beli első $m_{0}$ db sorösszeg és első $m_{0}$ db oszlopösszeg egyenletesen konvergens. Tehát létezik $n_{1}=n_{1}(\eta)$, amelyre

$$
|s(m, M ; n, N ; x, y)| \leq \frac{\eta}{2},
$$

ha $(x, y)$ tetszőleges, valamint $n_{1}<m \leq M$ és $1 \leq n \leq N<m_{0}$, vagy $1 \leq m \leq M<m_{0}$ és $n_{1}<n \leq N$. Legyen $n_{0}:=\max \left\{m_{0}, n_{1}\right\}$. Ekkor (2.13) és (2.14) alapján tetszőleges $(x, y)$ esetén $|s(m, M ; n, N ; x, y)| \leq \eta$, ha $n_{0}<m \leq M, 1 \leq n \leq N$ vagy $1 \leq m \leq M, n_{0}<n \leq$ $N$. Mivel $\eta$ tetszőleges volt, ezért az imént kapott egyenlőtlenség biztosítja számunkra (2.1) egyenletes, reguláris konvergenciáját. Ezzel beláttuk a tétel első részét.

(ii) rész: Tegyük fel, hogy $\left\{c_{j k}\right\} \subset \overline{\mathbb{R}}_{+}$és (2.1) reguláris konvergenciája egyenletes $(x, y)$-ban. Mivel $\left\{c_{j n}\right\}_{j=1}^{\infty} \in$ MVBVS bármely $n$-re, $\left\{c_{m k}\right\}_{k=1}^{\infty} \in$ MVBVS bármely $m$-re és a (2.12)-beli sor- ill. oszlopösszegek egyenletesen konvergensek $(x, y)$-ban, ezért az 1.1.2. Tétel szerint (2.2) fennáll azon esetekben, amikor $k$ rögzített és $j \rightarrow \infty$ ill. amikor $j$ rögzített és $k \rightarrow \infty$. Tehát elegendő belátnunk (2.2)-t abban az esetben, amikor $j$ és $k$ is a végtelenbe tart.

Legyen $m, n \geq 4 \lambda$ és

$$
x(m):=\frac{\pi}{2 \lambda m}, \quad y(n):=\frac{\pi}{2 \lambda n} .
$$

Ekkor bármely $[m / \lambda] \leq j \leq[\lambda m]$ esetén

$$
\frac{\pi}{8 \lambda^{2}}=\frac{m}{4 \lambda} \frac{\pi}{2 \lambda m} \leq\left(\frac{m}{2 \lambda}-1\right) \frac{\pi}{2 \lambda m} \leq j x(m) \leq \lambda m \frac{\pi}{2 \lambda m}=\frac{\pi}{2},
$$

ugyanígy,

$$
\frac{\pi}{8 \lambda^{2}} \leq k y(n) \leq \frac{\pi}{2}, \quad \text { ha } \quad[n / \lambda] \leq k \leq[\lambda n] .
$$

A 2.3.2. Lemmabeli (2.11)-et felhasználva kapjuk, hogy

$$
\sum_{j=[m / \lambda]}^{[\lambda m]} \sum_{k=[n / \lambda]}^{[\lambda n]} c_{j k} \sin (j x(m)) \sin (k y(n)) \geq \sin ^{2} \frac{\pi}{8 \lambda^{2}} \cdot \sum_{j=[m / \lambda]}^{[\lambda m]} \sum_{k=[n / \lambda]}^{[\lambda n]} c_{j k}
$$




$$
\geq \sin ^{2} \frac{\pi}{8 \lambda^{2}} \cdot \frac{1}{(3 C+2)} m n c_{m n},
$$

ahol a bal oldal tart a 0 -hoz, ha $m, n \rightarrow \infty$, mivel (2.1) reguláris konvergenciája egyenletes $(x, y)$-ban. Tehát (2.2)-t beláttuk a $j, k \rightarrow \infty$ esetben is, amivel a tétel második részét is igazoltuk.

Ezzel a 2.2.2. Tétel bizonyítást nyert.

\subsection{Az SBVDS $_{1}$ és $\mathrm{SBVDS}_{2}$ osztályok}

Célunk az MVBVDS osztály bővítése úgy, hogy a 2.2.2. Tételt általánosítani tudjuk. Ehhez két új sorozatosztályt definiálunk.

Definíció. $\left\{c_{j k}\right\}_{j, k=1}^{\infty} \subset \mathbb{C}$ kettős sorozat SBVDS - -beli (Supremum Bounded Variation Double Sequences of 1st type), ha léteznek olyan $C$ és $\lambda \geq 2$ konstansok illetve $\left\{b_{1}(l)\right\}_{l=1}^{\infty}$, $\left\{b_{2}(l)\right\}_{l=1}^{\infty},\left\{b_{3}(l)\right\}_{l=1}^{\infty}$ végtelenbe tartó sorozatok, melyek csak $\left\{c_{j k}\right\}$-tól függnek, és amelyekre

$$
\begin{aligned}
\sum_{j=m}^{2 m-1}\left|\Delta_{10} c_{j n}\right| & \leq \frac{C}{m} \max _{b_{1}(m) \leq M \leq \lambda b_{1}(m)} \sum_{j=M}^{2 M}\left|c_{j n}\right|, \quad m \geq \lambda, n \geq 1, \\
\sum_{k=n}^{2 n-1}\left|\Delta_{01} c_{m k}\right| & \leq \frac{C}{n} \max _{b_{2}(n) \leq N \leq \lambda b_{2}(n)} \sum_{k=N}^{2 N}\left|c_{m k}\right|, \quad m \geq 1, n \geq \lambda, \\
\sum_{j=m}^{2 m-1} \sum_{k=n}^{2 n-1}\left|\Delta_{11} c_{j k}\right| & \leq \frac{C}{m n} \sup _{M+N \geq b_{3}(m+n)} \sum_{j=M}^{2 M} \sum_{k=N}^{2 N}\left|c_{j k}\right|, \quad m, n \geq \lambda .
\end{aligned}
$$

Definíció. $\left\{c_{j k}\right\}_{j, k=1}^{\infty} \subset \mathbb{C}$ kettős sorozat SBVDS $_{2}$-beli (Supremum Bounded Variation Double Sequences of 2nd type), ha léteznek olyan $C, \lambda \geq 2$ konstansok és $\{b(l)\}_{l=1}^{\infty}$ végtelenbe tartó sorozat, melyek csak $\left\{c_{j k}\right\}$-tól függnek, és amelyekre

$$
\begin{aligned}
\sum_{j=m}^{2 m-1}\left|\Delta_{10} c_{j n}\right| & \leq \frac{C}{m} \sup _{M \geq b(m)} \sum_{j=M}^{2 M}\left|c_{j n}\right|, \quad m \geq \lambda, n \geq 1, \\
\sum_{k=n}^{2 n-1}\left|\Delta_{01} c_{m k}\right| & \leq \frac{C}{n} \sup _{N \geq b(n)} \sum_{k=N}^{2 N}\left|c_{m k}\right|, \quad m \geq 1, n \geq \lambda, \\
\sum_{j=m}^{2 m-1} \sum_{k=n}^{2 n-1}\left|\Delta_{11} c_{j k}\right| & \leq \frac{C}{m n} \sup _{M+N \geq b(m+n)} \sum_{j=M}^{2 M} \sum_{k=N}^{2 N}\left|c_{j k}\right|, \quad m, n \geq \lambda .
\end{aligned}
$$

Az egyváltozós esethez hasonlóan $\mathrm{SBVDS}_{2}$ definíciójában is feltehetjük, hogy $\{b(l)\}$ monoton nemcsökkenő, ha azonban az $\operatorname{SBVDS}_{1}$ definíciójánál használt $\left\{b_{1}(l)\right\}$ és $\left\{b_{2}(l)\right\}$ sorozatoktól elvárnánk, hogy monoton nemcsökkenők legyenek, akkor bizonyos $\left\{c_{j k}\right\}$ sorozatokat kivennénk az SBVDS 1 osztályból.

Az MVBVDS és az újonnan definiált sorozatosztályok között az alábbi tartalmazási reláció áll fenn. 
2.5.1. Tétel. [6] $\mathrm{SBVDS}_{2} \supsetneqq \mathrm{SBVDS}_{1} \supsetneqq \mathrm{MVBVDS}$

A 2.2.2. Tétel általánosítása a következő:

2.5.2. Tétel. [6] (i) $\mathrm{Ha} a\left\{c_{j k}\right\} \subset \mathbb{C}$ sorozat $\mathrm{SBVDS}_{2}$-beli, valamint (2.2) teljesül, akkor (2.1) reguláris konvergenciája egyenletes $(x, y)$-ban.

(ii) Megfordítva, ha a $\left\{c_{j k}\right\} \subset \overline{\mathbb{R}}_{+}$sorozat $\mathrm{SVBVDS}_{1}$-beli és (2.1) reguláris konvergenciája egyenletes $(x, y)$-ban, akkor (2.2) fennáll.

2.5.3. Következmény. Ha $a\left\{c_{j k}\right\} \subset \overline{\mathbb{R}}_{+}$sorozat $\mathrm{SBVDS}_{1}$-beli, akkor (2.2) szükséges és elegendő feltétele annak, hogy (2.1) reguláris konvergenciája egyenletes legyen ( $x, y)$ ban.

\subsection{A 2.5.1. és 2.5.2. Tételek bizonyítása}

A 2.5.1. Tétel bizonyítása. Könnyen látható, hogy $\operatorname{SBVDS}_{2} \supseteq \operatorname{SBVDS}_{1}$, hiszen a $\{b(l)=$ $\left.\min \left\{b_{1}(l), b_{2}(l), b_{3}(l)\right\}\right\}$ sorozat definiálása biztosítja számunkra, hogy bármely $\mathrm{SBVDS}_{1^{-}}$ beli sorozat $\mathrm{SBVDS}_{2}$-beli.

Ezután konstruálunk egy $\left\{c_{j k}\right\} \in \mathrm{SBVDS}_{2} \backslash \mathrm{SBVDS}_{1}$ sorozatot. E célból vegyünk egy tetszőleges pozitív nemnövő $\left\{d_{r}\right\}_{r=1}^{\infty}$ sorozatot, valamint legyen $m_{r}=2^{\left(2^{2 r}\right)},(r=1,2, \ldots)$. $\left\{c_{j k}\right\}$ első sora legyen az 1.2.1. Tétel bizonyításabeli első példasorozat megfelelője, mely SBVS-beli a $C=4$ és $\lambda=2$ konstansokkal:

$$
c_{j 1}:= \begin{cases}0, & \text { ha } \quad j<m_{1}, \\ d_{r}, & \text { ha } \quad j=m_{r}, \\ 0, & \text { ha } \quad m_{r}<j<m_{r}^{2}, \\ d_{r}, & \text { ha } \quad m_{r}^{2} \leq j<2 m_{r}^{2}, \\ 0, & \text { ha } 2 m_{r}^{2} \leq j<m_{r+1} .\end{cases}
$$

A második sor legyen az 1.2.1. Tétel bizonyításabeli második példasorozat megfelelője, mely $\mathrm{SBVS}_{2}$-beli a $C=4$ konstanssal és a $b(l)=l^{1 / 2}$ sorozattal:

$$
c_{j 2}:= \begin{cases}0, & \text { ha } j<m_{1}, \\ d_{r} n_{r}^{-2}, & \text { ha } j=m_{r}, \\ 0, & \text { ha } m_{r}<j<m_{r}^{2}, \\ d_{r+1} m_{r+1}^{-3 / 2}, & \text { ha } m_{r}^{2} \leq j \leq 2 m_{r}^{2}, \\ 0, & \text { ha } 2 m_{r}^{2}<j<m_{r+1} .\end{cases}
$$

Végül, a maradék sorok álljanak csupa 0-ból:

$$
c_{j k}:=0, \quad j \geq 1, k \geq 3
$$


Ekkor meggondolható, hogy semmilyen $C$ és $\lambda$ esetén sem definiálható olyan $\left\{b_{1}(l)\right\}$ sorozat, mely teljesítené a (2.15) feltételt minden $m \geq \lambda$-ra, mert elég nagy $m$ esetén vagy az $n=1$, vagy az $n=2$ esetben a kívánt egyenlőtlenség nem állna fenn (a logikusnak tűnő $\left\{b_{1}(l)\right\}=[l / 2]$ esetén az $m=m_{r}, n=2$ esetben elég nagy $r$-et véve sérül (2.15), míg a másik logikusnak tűnő $\left\{b_{1}(l)\right\}=l^{1 / 2}$ esetén az $m=m_{r}^{2}, n=1$ esetben sérül (2.15), ha $r$ elég nagy). Tehát $\left\{c_{j k}\right\} \notin \mathrm{SBVDS}_{1}$. Másrészről, $\left\{c_{j k}\right\}$ összes sora $\mathrm{SBVS}_{2}$-beli a $C=4$ konstanssal és a $b(l)=l^{1 / 2}$ sorozattal. Továbbá, (2.19) és (2.20) is fennáll tetszőleges $C$ és $\{b(l)\}$ választással, ha $\lambda$ értékét 3-nak definiáljuk. Tehát a (2.18)-(2.20) feltételek teljesülnek, ha $C=4, \lambda=3$ és $b(l)=l^{1 / 2}$, így $\left\{c_{j k}\right\} \in \mathrm{SBVDS}_{2}$. Az imént említett példa $\left\{c_{j k}\right\}$-ra igen egyszerü volt, hiszen csak két sorában volt nem nulla elem, de könnyen megadható jóval komplikáltabb SBVDS $_{2} \backslash \mathrm{SBVDS}_{1}$-beli sorozat is, melynek több sorában is van nem nulla elem (akár mindben).

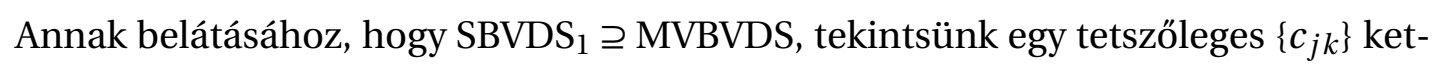
tős sorozatot, mely MVBVDS-beli a $C$ és $\lambda$ konstansokkal. Ekkor (2.15) fennáll a $C^{\prime}=$ $\left(\left[\lambda^{2}\right]+1\right) C, \lambda^{\prime}=\left[\lambda^{2}\right]+1$ és $b_{1}(l)=[l / \lambda]$ választással, hiszen (2.6) szerint

$$
\begin{aligned}
\sum_{j=m}^{2 m-1}\left|\Delta_{10} c_{j n}\right| & \leq \frac{C}{m} \sum_{j=[m / \lambda]}^{[\lambda m]}\left|c_{j n}\right| \leq \frac{C}{m} \sum_{r=1}^{\lambda^{\prime}} \sum_{j=r[m / \lambda]}^{2 r[m / \lambda]}\left|c_{j n}\right| \\
& \leq \frac{C^{\prime}}{m} \max _{[m / \lambda] \leq M \leq \lambda^{\prime}[m / \lambda]} \sum_{j=M}^{2 M}\left|c_{j n}\right|, \quad m \geq \lambda, n \geq 1 .
\end{aligned}
$$

Hasonlóan, (2.7) alkalmazásával megkapható, hogy (2.16) szintén fennáll a $C^{\prime}, \lambda^{\prime}$ és $b_{2}(l)=b_{1}(l)$ esetben. A (2.17) feltétel pedig (2.8)-ból következik:

$$
\begin{aligned}
\sum_{j=m}^{2 m-1} \sum_{k=n}^{2 n-1}\left|\Delta_{11} c_{j k}\right| & \leq \frac{C}{m n} \sum_{j=[m / \lambda]}^{[\lambda m]} \sum_{k=[n / \lambda]}^{[\lambda n]}\left|c_{j k}\right| \leq \frac{C}{m n} \sum_{r=1}^{\lambda^{\prime}} \sum_{s=1}^{\lambda^{\prime}} \sum_{j=r[m / \lambda]}^{2 r[m / \lambda]} \sum_{k=s[n / \lambda]}^{2 s[n / \lambda]}\left|c_{j k}\right| \\
& \leq \frac{\lambda^{\prime 2} C}{m n} \sup _{M+N \geq[m / \lambda]+[n / \lambda]} \sum_{j=M}^{2 M} \sum_{k=N}^{2 N}\left|c_{j k}\right|, \quad m, n \geq \lambda .
\end{aligned}
$$

Tehát $\left\{c_{j k}\right\} \in \operatorname{SBVDS}_{1}$ a $C^{\prime \prime}=\left(\left[\lambda^{2}\right]+1\right)^{2} C, \lambda^{\prime}=\left[\lambda^{2}\right]+1, b_{1}(l)=b_{2}(l)=[l / \lambda]$ és $b_{3}(l)=$ $[l / \lambda]-1$ választással.

Végül, könnyü belátni, hogy ha $\left\{c_{j k}\right\}$ olyan, hogy első sora, $\left\{c_{j 1}\right\}, \mathrm{SBVS}_{2} \backslash \mathrm{MVBVS}-$ beli és $c_{j k}=0$, ha $j \geq 1, k \geq 2$, akkor $\left\{c_{j k}\right\} \in \operatorname{SBVDS}_{1} \backslash$ MVBVDS. Nyilvánvalóan léteznek az előző példánál bonyolultabb SBVDS $_{1} \backslash$ MVBVDS-beli sorozatok is, de most csak azt mutattuk meg, hogy ilyen sorozatok léteznek.

Mint a 2.2.2. Tétel bizonyítása előtt tettük, most is bebizonyítunk két lemmát.

2.6.1. Lemma. Tegyük fel, hogy $\left\{c_{j k}\right\} \subset \mathbb{C}$ teljesíti a (2.2) és (2.20) feltételeket. Ekkor a 2.3.1.Lemma (2.9) és (2.10) állításai fennállnak. 
Bizonyítás. Legyen $\varepsilon>0$ tetszőleges. Ekkor (2.2) szerint létezik $m_{0}=m_{0}(\varepsilon)$ küszöbszám, melyre $j k\left|c_{j k}\right| \leq \varepsilon$ bármely $j+k>m_{0}$ esetén. Továbbá létezik olyan $m_{1}$, melyre bármely $j>m_{1}$ esetén $b(j)>m_{0}$. Így bármely $m+n>m_{1}, m, n \geq \lambda$-ra

$$
\begin{aligned}
\sum_{j=m}^{\infty} \sum_{k=n}^{\infty}\left|\Delta_{11} c_{j k}\right| & =\sum_{r=0}^{\infty} \sum_{s=0}^{\infty} \sum_{j=2^{r} m}^{2^{r+1} m-12^{s+1} n-1} \sum_{k=2^{s} n}^{n}\left|\Delta_{10} c_{j k}\right| \\
& \leq \sum_{r=0}^{\infty} \sum_{s=0}^{\infty} \frac{C}{2^{r+s} m n} \sup _{M+N \geq b\left(2^{r} m+2^{s} n\right)} \sum_{j=M}^{2 M} \sum_{k=N}^{2 N}\left|c_{j k}\right| \\
& \leq \frac{C \varepsilon}{m n} \sum_{r=0}^{\infty} \sum_{s=0}^{\infty} \frac{1}{2^{r+s}} \sup _{M+N \geq b\left(2^{r} m+2^{s} n\right)} \sum_{j=M}^{2 M} \sum_{k=N}^{2 N} \frac{1}{j k} \\
& \leq \frac{4 C \varepsilon}{m n} \sum_{r=0}^{\infty} \sum_{s=0}^{\infty} \frac{1}{2^{r+s}} \leq \frac{16 C \varepsilon}{m n},
\end{aligned}
$$

ezzel (2.9)-et igazoltuk. Innen (2.10) a korábban látott módon következik.

2.6.2. Lemma. Legyen $\left\{c_{j k}\right\} \subset \overline{\mathbb{R}}_{+}$SBVDS $_{1}$-beli a $C$ és $\lambda \geq 2$ konstansokkal, valaminta $\left\{b_{1}(l)\right\},\left\{b_{2}(l)\right\},\left\{b_{3}(l)\right\}$ sorozatokkal. Ekkor

$$
\begin{aligned}
m n c_{m n} \leq & C \sup _{M+N \geq b_{3}(m+n)} \sum_{j=M}^{2 M} \sum_{k=N}^{2 N} c_{j k}+C \sum_{j=b_{1}(m)}^{2 \lambda b_{1}(m)} \sum_{k=n}^{2 n} c_{j k} \\
& +C \sum_{j=m}^{2 m} \sum_{k=b_{2}(n)}^{2 \lambda b_{2}(n)} c_{j k}+2 \sum_{j=m}^{2 m} \sum_{k=n}^{2 n} c_{j k}, \quad \text { ha } m, n \geq \lambda .
\end{aligned}
$$

Bizonyítás. Legyen $m, n \geq \lambda$ tetszőleges. Ekkor (2.15) szerint bármely $m+1 \leq \mu \leq 2 m$ és $v$ egész számokra

$$
\begin{aligned}
c_{m v} & \leq \sum_{j=m}^{2 m-1}\left|\Delta_{10} c_{j v}\right|+c_{\mu v} \leq \frac{C}{m} \max _{b_{1}(m) \leq M \leq \lambda b_{1}(m)} \sum_{j=M}^{2 M} c_{j v}+c_{\mu v} \\
& \leq \frac{C}{m} \sum_{j=b_{1}(m)}^{2 \lambda b_{1}(m)} c_{j v}+c_{\mu v} .
\end{aligned}
$$

Hasonlóan, (2.16)-ot használva adódik, hogy bármely $\mu$ és $n+1 \leq v \leq 2 n$-re

$$
c_{\mu n} \leq \frac{C}{n} \sum_{k=b_{2}(n)}^{2 \lambda b_{2}(n)} c_{\mu k}+c_{\mu v} .
$$

(2.17) szerint bármely $m+1 \leq \mu \leq 2 m, n+1 \leq v \leq 2 n$ egész számokra fennáll a következő:

$$
\begin{aligned}
c_{m n} & \leq \sum_{j=m}^{2 m-1} \sum_{k=n}^{2 n-1}\left|\Delta_{11} c_{j k}\right|+c_{m v}+c_{\mu n} \\
& \leq \frac{C}{m n} \sup _{M+N \geq b_{3}(m+n)} \sum_{j=M}^{2 M} \sum_{k=N}^{2 N} c_{j k}+c_{m v}+c_{\mu n} .
\end{aligned}
$$


Ezt összevetve az előbb kapott két egyenlőtlenséggel adódik, hogy

$$
c_{m n} \leq \frac{C}{m n} \sup _{M+N \geq b_{3}(m+n)} \sum_{j=M}^{2 M} \sum_{k=N}^{2 N} c_{j k}+\frac{C}{m} \sum_{j=b_{1}(m)}^{2 \lambda b_{1}(m)} c_{j v}+\frac{C}{n} \sum_{k=b_{2}(n)}^{2 \lambda b_{2}(n)} c_{\mu k}+2 c_{\mu v} .
$$

Behelyettesítve az előbb kapott egyenlőtlenségbe a $\mu=m+1, \ldots, 2 m, v=n+1, \ldots, 2 n$ értékeket, majd összeadva a megfelelő oldalakat kapjuk, hogy

$$
\begin{aligned}
m n c_{m n} \leq & C \sup _{M+N \geq b_{3}(m+n)} \sum_{j=M}^{2 M} \sum_{k=N}^{2 N} c_{j k}+\sum_{v=n+1}^{2 n} C \sum_{j=b_{1}(m)}^{2 \lambda b_{1}(m)} c_{j v} \\
& +\sum_{\mu=m+1}^{2 m} C \sum_{k=b_{2}(n)}^{2 \lambda b_{2}(n)} c_{\mu k}+2 \sum_{\mu=m+1}^{2 m} \sum_{v=n+1}^{2 n} c_{\mu v},
\end{aligned}
$$

amiből következik (2.21), ezzel a lemma állítását beláttuk.

A 2.5.2. Tétel bizonyítása. (i) rész: Legyen $\left\{c_{j k}\right\} \in \mathrm{SBVDS}_{2}$, és tegyük fel, hogy (2.2) fennáll. Ekkor a (2.18) és (2.19) feltételek teljesülése miatt $\left\{c_{j n}\right\}_{j=1}^{\infty} \in \mathrm{SBVS}_{2}$ bármely $n$ re és $\left\{c_{m k}\right\}_{k=1}^{\infty} \in \mathrm{SBVS}_{2}$ bármely $m$-re, így az 1.2.2. Tétel szerint a (2.12)-beli sor- és oszlopösszegek egyenletesen konvergensek $x$-ben ill. $y$-ban. Ezen észrevétel után a (2.1) egyenletes, reguláris konvergenciája a 2.2.2. Tétel bizonyításának megismétlésével igazolható, csupán a 2.3.1. Lemma helyett a 2.6.1. Lemmát kell alkalmaznunk.

(ii) rész: Ezúttal tegyük fel, hogy $\left\{c_{j k}\right\} \subset \overline{\mathbb{R}}_{+} \operatorname{SBVDS}_{1}$-beli és (2.1) reguláris konvergenciája egyenletes $(x, y)$-ban. Mivel a $\left\{c_{j n}\right\}_{j=1}^{\infty}$ sorok és a $\left\{c_{m k}\right\}_{k=1}^{\infty}$ oszlopok is $\mathrm{SBVS}_{2}$ beliek, ezért a (2.12)-beli sor- és oszlopösszegek egyenletesen konvergensek $(x, y)$-ban, és így az 1.2.2. Tétel szerint (2.2) fennáll, ha $j \rightarrow \infty$ és $k$ rögzített illetve ha $j$ rögzített és $k \rightarrow \infty$. Annak igazolásához, hogy (2.2) teljesül akkor is, amikor $j$ és $k$ is a végtelenbe tart, legyen $m, n \geq 4 \lambda$ és

$$
x_{1}(m):=\frac{\pi}{4 m}, \quad x_{2}(m):=\frac{\pi}{4 \lambda m}, \quad y_{1}(n):=\frac{\pi}{4 n}, \quad y_{2}(n):=\frac{\pi}{4 \lambda n} .
$$

Ekkor (a korábban már látott módon) megmutatható, hogy

$$
\begin{gathered}
\sin \left(j x_{1}(m)\right), \sin \left(k y_{1}(n)\right) \geq \frac{1}{\sqrt{2}}, \quad \text { ha } \quad m \leq j \leq 2 m, n \leq k \leq 2 n, \\
\sin \left(j x_{2}(m)\right), \sin \left(k y_{2}(n)\right) \geq \sin \frac{\pi}{4 \lambda}, \quad \text { ha } \quad m \leq j \leq 2 \lambda m, n \leq k \leq 2 \lambda n .
\end{gathered}
$$

A 2.6.2. Lemma szerint

$$
\begin{aligned}
& C \sup _{M+N \geq b_{3}(m+n)} \sum_{j=M}^{2 M} \sum_{k=N}^{2 N} c_{j k} \sin \left(j x_{1}(M)\right) \sin \left(k y_{1}(N)\right) \\
& +C \sum_{j=b_{1}(m)}^{2 \lambda b_{1}(m)} \sum_{k=n}^{2 n} c_{j k} \sin \left(j x_{2}(m)\right) \sin \left(k y_{1}(n)\right)
\end{aligned}
$$




$$
\begin{aligned}
& +C \sum_{j=m}^{2 m} \sum_{k=b_{2}(n)}^{2 \lambda b_{2}(n)} c_{j k} \sin \left(j x_{1}(m)\right) \sin \left(k y_{2}(n)\right) \\
& +2 \sum_{j=m}^{2 m} \sum_{k=n}^{2 n} c_{j k} \sin \left(j x_{1}(m)\right) \sin \left(k y_{1}(n)\right) \\
& \geq \frac{C}{2} \sup _{M+N \geq b_{3}(m+n)} \sum_{j=M}^{2 M} \sum_{k=N}^{2 N} c_{j k}+C \sin \left(\frac{\pi}{4 \lambda}\right) \frac{1}{\sqrt{2}} \sum_{j=b_{1}(m)}^{2 \lambda b_{1}(m)} \sum_{k=n}^{2 n} c_{j k} \\
& +C \frac{1}{\sqrt{2}} \sin \left(\frac{\pi}{4 \lambda}\right) \sum_{j=m}^{2 m} \sum_{k=b_{2}(n)}^{2 \lambda b_{2}(n)} c_{j k}+\sum_{j=m}^{2 m} \sum_{k=n}^{2 n} c_{j k} \\
& \quad \geq \min \left\{\frac{C}{\sqrt{2}} \sin \frac{\pi}{4 \lambda}, 1\right\} m n c_{m n} .
\end{aligned}
$$

Mivel bármely $x, y$ esetén

$$
\sum_{j=m}^{M} \sum_{k=N}^{N} c_{j k} \sin j x \sin k y \rightarrow 0, \quad \text { ha } m, n \rightarrow \infty,
$$

ezért a (2.22) bal oldala 0 -hoz tart, ha $m, n$ tart a végtelenbe, hiszen a $\left\{b_{1}\right\}$, $\left\{b_{2}\right\}$ és $\left\{b_{3}\right\}$ sorozatok a végtelenbe tartanak. Így (2.2) teljesül akkor is, amikor $j, k$ tart a végtelenbe. Ezzel a 2.5.2. Tétel második részét is beláttuk. 


\section{3. fejezet}

\section{Szinuszintegrálok}

\subsection{Elözmények}

Legyen $f: \mathbb{R}_{+} \rightarrow \mathbb{C}$ Lebesgue-mérhető függvény, ahol $\mathbb{R}_{+}:=(0, \infty)$. A fejezet során az

$$
\int_{0}^{\infty} f(x) \sin t x d x
$$

alakú szinuszintegrálok $t$-ben vett egyenletes konvergenciáját vizsgáljuk, ahol $t \in \mathbb{R}$. Mivel a szinusz függvény páratlan, és a 0 helyen eltűnik, ezért az általánosság megszorítása nélkül feltehetjük, hogy $t \in \mathbb{R}_{+}$. A (3.1) integrál konvergenciája az

$$
\int_{0}^{b} f(x) \sin t x d x
$$

improprius részletintegrálok konvergenciáját jelenti, ahol $b$ tart a végtelenbe. Annak érdekében, hogy biztosítsuk az iménti részletintegrálok létezését (véges értékét), a továbbiakban feltesszük, hogy $x f(x)$ lokálisan integrálható az $\overline{\mathbb{R}}_{+}$zárt félegyenesen:

$$
x f(x) \in L_{\mathrm{loc}}^{1}\left(\overline{\mathbb{R}}_{+}\right),
$$

ekkor ugyanis

$$
\left|\int_{0}^{b} f(x) \sin t x d x\right| \leq t \int_{0}^{b} x|f(x)| d x<\infty, \quad b, t>0 .
$$

A (3.2) feltétel egyben azt is biztosítja, hogy $f$ a 0-n kívül lokálisan integrálható, azaz $f(x) \in L_{\text {loc }}^{1}\left(\mathbb{R}_{+}\right)$, hiszen

$$
\int_{a}^{b}|f(x)| d x \leq \frac{1}{a} \int_{a}^{b} x|f(x)| d x<\infty, \quad a>0 .
$$


Összevetve (1.1) és (3.1) alakját, megállapíthatjuk, hogy (3.1) a (1.1) nem diszkrét megfelelője (a szinuszsorbeli $x$ szerepét az integrálbeli $t$ veszi át), ezt az ezután következő tételek is alátámasztanak. Az analógiát azonban árnyalja az a tény, hogy míg a szinuszsorok esetében az összegfüggvény $2 \pi$ szerint periodikus, addig a szinuszintegrálok nem feltétlenül periodikus függvények, ez például az $L^{1}$-konvergencia vizsgálatakor jelent problémát (az általunk vizsgált egyenletes konvergencia esetében nem).

Elsőként a nemnegatív, monoton nemnövő $f$ függvények által meghatározott (3.1) integrálokra bebizonyított tételt ismertetjük. Ezen tétel az 1.1.1. Tétel nem diszkrét, nem periodikus megfelelője.

3.1.1. Tétel. [10] Legyen $f(x): \mathbb{R}_{+} \rightarrow \overline{\mathbb{R}}_{+}$monoton nemnövö, melyre (3.2) fennáll. Ekkor $a$ (3.1) szinuszintegrál akkor és csak akkor egyenletesen konvergens $t$-ben, ha

$$
x f(x) \rightarrow 0, \quad \text { ha } \quad x \rightarrow \infty .
$$

Az iménti tétel általánosításához alapötletet nyújt az 1.1. alfejezetben taglalt általánosított sorozatosztályok fogalma. Ennek megfelelően általánosított monoton függvényosztályokat fogunk definiálni. A diszkrét esetben használt $\Delta$ kifejezést (ami változást jelöl), felváltja a derivált fogalma. Ezen céllal az $f$ függvényről azt is fel fogjuk tenni, hogy lokálisan abszolút folytonos $\mathbb{R}_{+}-$on, jelölésben $f(x) \in \mathrm{AC}_{\text {loc }}\left(\mathbb{R}_{+}\right)$, hiszen ekkor $f$-nek majdnem mindenütt létezik a deriváltja, $f^{\prime}$, és $f^{\prime}$ lokálisan Lebesgueintegrálható, valamint

$$
\int_{a}^{b} f^{\prime}(x) d x=f(b)-f(a), \quad b>a>0 .
$$

Az általánosított függvényosztályok közül az NBVS és az MVBVS sorozatosztályok megfelelői a következők:

Definíció. Az $f(x) \in \mathrm{AC}_{\text {loc }}\left(\mathbb{R}_{+}\right)$függvényt $\operatorname{NBVF}\left(\mathbb{R}_{+}\right)$-belinek (Non-onesided Bounded Variation Function-nek) nevezzük, ha léteznek a $C, A>0$ konstansok, melyekre $f$ teljesíti az

$$
\int_{a}^{2 a}\left|f^{\prime}(x)\right| d x \leq C(|f(a)|+|f(2 a)|), \quad a>A
$$

feltételt.

Definíció. Az $f(x) \in \mathrm{AC}_{\text {loc }}\left(\mathbb{R}_{+}\right)$függvényt $\operatorname{MVBVF}\left(\mathbb{R}_{+}\right)$-belinek (Mean Value Bounded Variation Function-nek) nevezzük, ha léteznek a $C, A>0$ és $\lambda \geq 2$ konstansok, melyek 
csak $f$-től függnek, és amelyekre

$$
\int_{a}^{2 a}\left|f^{\prime}(x)\right| d x \leq \frac{C}{a} \int_{a / \lambda}^{\lambda a}|f(x)| d x, \quad a>A .
$$

[10]-ben belátták, hogy $\operatorname{MVBVF}\left(\mathbb{R}_{+}\right) \supseteq \operatorname{NBVF}\left(\mathbb{R}_{+}\right)$. $\operatorname{MVBVF}\left(\mathbb{R}_{+}\right) \backslash \operatorname{NBVF}\left(\mathbb{R}_{+}\right)$-beli függvényre példa $\mathrm{az} \frac{1}{1+x} \sin \left(\frac{\pi}{\ln 2} \ln x\right)$ függvény (lásd 4.2.1. Tétel bizonyítása). Továbbá a következő tétel is bebizonyítást nyert:

3.1.2. Tétel. [10] Tegyük fel, hogy $f(x) \in \operatorname{MVBVF}\left(\mathbb{R}_{+}\right)$, és (3.2) fennáll.

(i) Ha $f: \mathbb{R}_{+} \rightarrow \mathbb{C}$ és (3.3) teljesül, akkor a (3.1) integrál egyenletesen konvergens $t$-ben.

(ii) Megfordítva, ha $f: \mathbb{R}_{+} \rightarrow \overline{\mathbb{R}}_{+}$és (3.1) konvergenciája egyenletes $t$-ben, akkor (3.3) fennáll.

Mivel a nemnegatív, monoton nemnövő függvények nem feltétlenül lokálisan abszolút konvergensek, de az $\operatorname{MVBVF}\left(\mathbb{R}_{+}\right)$-beli függvények igen, ezért $\operatorname{MVBVF}\left(\mathbb{R}_{+}\right)$nem tartalmazza a nemnegatív, monoton nemnövő függvények osztályát, azaz a 3.1.2. Tétel nem a 3.1.1. Tétel általánosítása. Ha azonban az $f$ nemnegatív, monoton nemnövő függvényről feltesszük, hogy $f \in \mathrm{AC}_{\text {loc }}\left(\mathbb{R}_{+}\right)$, akkor $f^{\prime}(x) \geq 0$ miatt világos, hogy $f \in \operatorname{NBVF}\left(\mathbb{R}_{+}\right)$(és így $f \in \operatorname{MVBVF}\left(\mathbb{R}_{+}\right)$), ezért a lokálisan abszolút konvergens függvények körében a 3.1.1. Tételt általánosítja a 3.1.2. Tétel.

\section{2. Új eredmények}

Célunk a 3.1.2. Tétel kiterjesztése $\operatorname{MVBVF}\left(\mathbb{R}_{+}\right)$-nál bővebb függvényosztály(ok)ra. Ehhez segítséget jelentenek az 1.2. alfejezetben definiált sorozatosztályok. Azok nem diszkrét megfelelőit a következőképpen definiáljuk.

Definíció. Az $f(x) \in \mathrm{AC}_{\text {loc }}\left(\mathbb{R}_{+}\right.$) függvényt $\operatorname{SBVF}\left(\mathbb{R}_{+}\right)$-belinek (Supremum Bounded Variation Function-nek) nevezzük, ha léteznek a $C, A>0$ és $\lambda \geq 2$ konstansok, melyek csak $f$-től függnek, és amelyekre

$$
\int_{a}^{2 a}\left|f^{\prime}(x)\right| d x \leq \frac{C}{a} \sup _{b \geq a / \lambda} \int_{b}^{2 b}|f(x)| d x, \quad a>A .
$$

Definíció. Az $f(x) \in \mathrm{AC}_{\text {loc }}\left(\mathbb{R}_{+}\right)$függvény $\mathrm{SBVF}_{2}\left(\mathbb{R}_{+}\right)$-beli (Supremum Bounded Variation Function of 2nd type), ha léteznek a $C, A>0$ konstansok és a $B(x) \subset \overline{\mathbb{R}}_{+}$végtelenbe tartó függvény, melyek csak $f$-től függnek, és amelyekre

$$
\int_{a}^{2 a}\left|f^{\prime}(x)\right| d x \leq \frac{C}{a} \sup _{b \geq B(a)} \int_{b}^{2 b}|f(x)| d x, \quad a>A .
$$


A diszkrét esethez hasonlóan, ha az előbbi definícióban szereplő $B(x)$ függvényről megszabjuk, hogy monoton nemcsökkenő legyen, $\mathrm{SBVF}_{2}\left(\mathbb{R}_{+}\right)$tartalma változatlan marad.

Megmutatjuk, hogy az MVBVF $\left(\mathbb{R}_{+}\right), \operatorname{SBVF}\left(\mathbb{R}_{+}\right)$és $\mathrm{SBVF}_{2}\left(\mathbb{R}_{+}\right)$osztályok között valódi tartalmazási reláció áll fenn.

3.2.1. Tétel. [5] Ha $f(x) \in \operatorname{MVBVF}\left(\mathbb{R}_{+}\right)$, akkor $f(x) \in \operatorname{SBVF}\left(\mathbb{R}_{+}\right)$. A fordított irányú állitás nem igaz, azaz létezik olyan $f(x) \in \operatorname{SBVF}\left(\mathbb{R}_{+}\right)$, mely nem $\operatorname{MVBVF}\left(\mathbb{R}_{+}\right)$-beli. Röviden, $\operatorname{SBVF}\left(\mathbb{R}_{+}\right) \supsetneqq \operatorname{MVBVF}\left(\mathbb{R}_{+}\right)$.

3.2.2. Tétel. [5] $\operatorname{SBVF}_{2}\left(\mathbb{R}_{+}\right) \supsetneqq \operatorname{SBVF}\left(\mathbb{R}_{+}\right)$. Továbbá, ha $f(x) \mathrm{SBVF}_{2}\left(\mathbb{R}_{+}\right)$-beli, de nem $\operatorname{SBVF}\left(\mathbb{R}_{+}\right)$-beli, akkor (3.3) fennáll.

3.2.3. Tétel. [5] $\mathrm{Ha} f(x) \in \mathrm{SBVF}_{2}\left(\mathbb{R}_{+}\right)$és (3.2) fennáll, akkor a 3.1.2. Tétel (i) és (ii) állításai teljesülnek $f(x)$-re.

3.2.4. Következmény. $H a f: \mathbb{R}_{+} \rightarrow \overline{\mathbb{R}}_{+} \mathrm{SBVF}_{2}\left(\mathbb{R}_{+}\right)$-beli, akkor (3.3) szükséges és elegendö feltétele annak, hogy (3.1) egyenletesen konvergens legyen t-ben.

\subsection{Az állítások igazolása}

A 3.2.1. Tétel bizonyítása. Annak igazolásához, hogy bármely $\operatorname{MVBVF}\left(\mathbb{R}_{+}\right)$-beli függvény $\operatorname{SBVF}\left(\mathbb{R}_{+}\right)$-beli is, legyen $f \in \operatorname{MVBVF}\left(\mathbb{R}_{+}\right)$a hozzá tartozó $C, A>0$ és $\lambda \geq 2$ konstansokkal. Továbbá jelöljük $\mu$-vel azt az egész számot, melyre $2^{\mu} \leq \lambda^{2}<2^{\mu+1}$. Ekkor (3.4) szerint bármely $a>A$ esetén

$$
\begin{aligned}
\int_{a}^{2 a}\left|f^{\prime}(x)\right| d x & \leq \frac{C}{a} \int_{a / \lambda}^{\lambda a}|f(x)| d x \leq \frac{C}{a}\left\{\int_{a / \lambda}^{2 a / \lambda}+\int_{2 a / \lambda}^{4 a / \lambda}+\ldots+\int_{2^{\mu} a / \lambda}^{2^{\mu+1} a / \lambda}\right\}|f(x)| d x \\
& \leq \frac{(\mu+1) C}{a} \sup _{b \geq a / \lambda} \int_{b}^{2 b}|f(x)| d x .
\end{aligned}
$$

Tehát $f \operatorname{SBVF}\left(\mathbb{R}_{+}\right)$-beli a $(\mu+1) C, A$ és $\lambda$ konstansokkal.

Ezután megadunk egy olyan $f$ függvényt, mely $\operatorname{SBVF}\left(\mathbb{R}_{+}\right) \backslash \operatorname{MVBVF}\left(\mathbb{R}_{+}\right)$-beli. Bebizonyítjuk, hogy az $f_{1}(x)=\sin x / \ln (1+x)$ nullához tartó függvény ilyen. Egyrészről, bármely $a>2 \pi$-re igaz az

$$
\int_{a}^{2 a}\left|f_{1}^{\prime}(x)\right| d x=\int_{a}^{2 a}\left|\frac{\cos x}{\ln (1+x)}-\frac{\sin x}{(1+x) \ln ^{2}(1+x)}\right| d x
$$




$$
\begin{aligned}
& \geq \int_{a}^{2 a}\left|\frac{\cos x}{\ln (1+x)}\right| d x-\int_{a}^{2 a}\left|\frac{\sin x}{(1+x) \ln ^{2}(1+x)}\right| d x \\
& \geq \frac{a}{\pi \ln (1+2 a)}-\frac{4 a}{\pi a \ln ^{2}(1+a)},
\end{aligned}
$$

egyenlőtlenséglánc, így

$$
\int_{a}^{2 a}\left|f_{1}^{\prime}(x)\right| d x \rightarrow \infty, \quad \text { ha } \quad a \rightarrow \infty .
$$

Ellenben, $a>2 \lambda \geq 4$ esetén

$$
\frac{C}{a} \int_{a / \lambda}^{\lambda a}\left|f_{1}(x)\right| d x \leq \frac{C}{a \ln (a / \lambda)} \int_{a / \lambda}^{\lambda a}|\sin (x)| d x \leq \frac{C}{a \ln (a / \lambda)} \cdot \frac{4 \lambda a}{\pi} \leq \frac{4 \lambda C}{\pi \ln 2} .
$$

Tehát nem léteznek olyan $C$, $A$ és $\lambda$ konstansok, melyekre fennáll a (3.4) egyenlőtlenség minden $a>A$ esetén, azaz $f_{1} \notin \operatorname{MVBVF}\left(\mathbb{R}_{+}\right)$. Másrészről viszont $f_{1} \in \operatorname{SBVF}\left(\mathbb{R}_{+}\right)$, hiszen $a>\pi$ esetén

$$
\begin{aligned}
\int_{a}^{2 a}\left|f_{1}^{\prime}(x)\right| d x & \leq \int_{a}^{2 a}\left|\frac{\cos x}{\ln (1+x)}\right| d x+\int_{a}^{2 a}\left|\frac{\sin x}{(1+x) \ln ^{2}(1+x)}\right| d x \leq \frac{8 a}{\pi \ln (1+a)} \\
& \leq \frac{8 \ln \left(1+2 a^{2}\right)}{a \ln (1+a)} \int_{a^{2}}^{2 a^{2}}\left|\frac{\sin x}{\ln (1+x)}\right| d x \leq \frac{24}{a} \sup _{b \geq a / \lambda} \int_{b}^{2 b}\left|f_{1}(x)\right| d x,
\end{aligned}
$$

ahol $\lambda \geq 2$ értékét tetszőlegesen választhatjuk; ez pedig azt jelenti, hogy (3.5) fennáll a $C=24, A=\pi$ és $\lambda=2$ konstansokkal.

Hasonló érveléssel igazolható, hogy pl. az $f_{2}(x)=\sin x, f_{3}(x)=\sin x /(1+x), f_{4}(x)=$ $\sin x /(1+x)^{2}$ függvények is $\operatorname{SBVF}\left(\mathbb{R}_{+}\right) \backslash \operatorname{MVBVF}\left(\mathbb{R}_{+}\right)$-beliek. A felsorolt példákat azért érdemes megemlíteni, mert érzékelteti, hogy az $\operatorname{SBVF}\left(\mathbb{R}_{+}\right)$osztályban vannak olyan nem $\operatorname{MVBVF}\left(\mathbb{R}_{+}\right)$-beli függvények, melyek különböző tulajdonságúak:

$$
f_{1}(x) \rightarrow 0, x f_{1}(x) \rightarrow \infty ; f_{3}(x) \rightarrow 0, x f_{3}(x) \rightarrow 1 \text { és } f_{4}(x) \rightarrow 0, x f_{4}(x) \rightarrow 0
$$

A 3.2.2. Tétel bizonyítása. Nyilvánvaló, hogy ha a (3.5) egyenlőtlenség fennáll, akkor (3.6) is fennáll, mégpedig a $B(x)=x / \lambda$ választással. Tehát az $\mathrm{SBVF}_{2}\left(\mathbb{R}_{+}\right)$osztály tartalmazza $\operatorname{SBVF}\left(\mathbb{R}_{+}\right)$-t. Ezután megmutatjuk, hogy az $f(x)=\sin x /(1+x)^{3}$ függvény $\mathrm{SBVF}_{2}\left(\mathbb{R}_{+}\right) \backslash \mathrm{SBVF}\left(\mathbb{R}_{+}\right)$-beli. Egyrészről, bármely $a>2 \pi$ esetén

$$
\int_{a}^{2 a}\left|f^{\prime}(x)\right| d x=\int_{a}^{2 a}\left|\frac{\cos x}{(1+x)^{3}}-\frac{3 \sin x}{(1+x)^{4}}\right| d x \geq \int_{a}^{2 a}\left|\frac{\cos x}{(1+x)^{3}}\right| d x-\int_{a}^{2 a}\left|\frac{3 \sin x}{(1+x)^{4}}\right| d x
$$




$$
\geq \frac{a}{\pi(1+2 a)^{3}}-\frac{12 a}{\pi(1+a)^{4}},
$$

így

$$
\int_{a}^{2 a}\left|f^{\prime}(x)\right| d x \sim \frac{1}{8 \pi a^{2}}
$$

Viszont $a>\lambda \geq 2$ esetén

$$
\begin{aligned}
\frac{C}{a} \sup _{b \geq a / \lambda} \int_{b}^{2 b}\left|f_{2}(x)\right| d x & \leq \frac{C}{a} \sup _{b \geq a / \lambda} \frac{1}{(1+b)^{3}} \int_{b}^{2 b}|\sin (x)| d x \\
& \leq \frac{C}{a} \sup _{b \geq a / \lambda} \frac{4 b}{\pi(1+b)^{3}}=\frac{4 C}{\lambda \pi(1+a / \lambda)^{3}}=\frac{4 C \lambda^{2}}{\pi(\lambda+a)^{3}},
\end{aligned}
$$

azaz nem léteznek olyan $C$, $A$ és $\lambda$ konstansok, melyekre fennáll a (3.5) egyenlőtlenség minden $a>A$ esetén, tehát $f \notin \operatorname{SBVF}\left(\mathbb{R}_{+}\right)$. Másrészről, $a>4 \pi^{2}$-re teljesül a következő:

$$
\begin{aligned}
\int_{a}^{2 a}\left|f_{2}^{\prime}(x)\right| d x & \leq \int_{a}^{2 a}\left|\frac{\cos x}{(1+x)^{3}}\right| d x+\int_{a}^{2 a}\left|\frac{3 \sin x}{(1+x)^{4}}\right| d x \leq \frac{16 a}{\pi(1+a)^{3}} \\
& \leq \frac{16 \sqrt{a}(1+2 \sqrt{a})^{3}}{(1+a)^{3}} \int_{\sqrt{a}}^{2 \sqrt{a}}\left|\frac{\sin x}{(1+x)^{3}}\right| d x \leq \frac{320}{a} \sup _{b \geq \sqrt{a}} \int_{b}^{2 b}\left|f_{2}(x)\right| d x .
\end{aligned}
$$

Így (3.6) fennáll a $C=320, A=4 \pi^{2}$ konstansokkal és a $B(x)=\sqrt{x}$ választással, azaz $f \in \operatorname{SBVF}_{2}\left(\mathbb{R}_{+}\right)$.

Végül, a tétel utolsó állításának igazolásához tekintsünk egy tetszőleges $\operatorname{SBVF}_{2}\left(\mathbb{R}_{+}\right) \backslash$ $\operatorname{SBVF}\left(\mathbb{R}_{+}\right)$-beli $f$ függvényt. $C, A$ és $B(x)$ legyenek az $f$-hez tartozó, (3.6)-beli konstansok ill. függvény. Továbbá legyen

$$
I_{a}:=\sup _{b \geq a} \int_{b}^{2 b}|f(x)| d x \quad \text { és } \quad I:=\limsup _{a \rightarrow \infty} I_{a},
$$

ahol $I_{a}, I \in[0, \infty]$. Nyilvánvaló, hogy $I_{a}$ monoton nemnövő függvénye $a$-nak. Ezért ha $I=\infty$, akkor $I_{a}=\infty$ minden $a$ esetén, és így (3.5) fennáll a $C$ és $A$ konstansokkal és tetszőleges $\lambda$-val, ami ellentmondás, hiszen $f \notin \operatorname{SBVF}\left(\mathbb{R}_{+}\right)$. Ha $0<I<\infty$, akkor létezik olyan $A^{\prime}(>A)$, melyre $I<I_{a}<J<\infty$ bármely $a>A^{\prime}$ esetén. Ekkor is ellentmondásra jutunk, hiszen (3.5) fennáll a $C \cdot J / I$ és $A^{\prime \prime}$ konstansokkal és tetszőleges $\lambda$-val, ahol $A^{\prime \prime}$ az a szám, melyre bármely $a>A^{\prime \prime}$ teljesíti $B(a)>A^{\prime}$-t. Végül, ha $I=0$, akkor a következőképpen gondolkodunk:

$$
f(t)-f(a)=f(t)+\int_{a}^{t} f^{\prime}(x) d x, \quad a<t,
$$


így

$$
|f(a)| \leq|f(t)|+\int_{a}^{t}\left|f^{\prime}(x)\right| d x \leq|f(t)|+\int_{a}^{2 a}\left|f^{\prime}(x)\right| d x \quad a<t<2 a .
$$

Integrálva $t$ szerint az iménti egyenlőtlenséglánc bal és jobb oldalát az [ $a, 2 a]$ intervallumon, figyelembe véve (3.6)-ot, adódik, hogy

$$
\begin{aligned}
a|f(a)| & \leq \int_{a}^{2 a}|f(t)| d t+a \int_{a}^{2 a}\left|f^{\prime}(x)\right| d x \\
& \leq \int_{a}^{2 a}|f(x)| d x+C \sup _{b \geq B(a)} \int_{b}^{2 b}|f(x)| d x=I_{a}+C \cdot I_{B(a)}
\end{aligned}
$$

bármely $a>A$-ra. Innen pedig következik (3.3), hiszen $\lim I_{a}=\lim I_{B(a)}=0$.

A 3.2.3. Tétel bizonyítása. Legyen $f \in \mathrm{SBVF}_{2}\left(\mathbb{R}_{+}\right)$a $C, A$ konstansokkal és $B(x)$-szel, valamint tegyük fel, hogy (3.2) fennáll.

(i) rész: Tegyük fel, hogy (3.3) teljesül. Megmutatjuk, hogy ekkor

$$
a \int_{a}^{\infty}\left|f^{\prime}(x)\right| d x \rightarrow 0, \quad \text { ha } a \rightarrow \infty .
$$

Rögzítsünk egy tetszőleges $\varepsilon>0$ számot. (3.3) szerint létezik olyan $x_{0}$ küszöbszám, melyre $x|f(x)|<\varepsilon$, ha $x>x_{0}$. Mivel $\mathrm{B}(\mathrm{x})$ tart a végtelenbe, ezért létezik $x_{1}$ úgy, hogy bármely $x>x_{1}$ teljesíti a $B(x)>x_{0}$ egyenlőtlenséget. Ekkor (3.6)-ot használva adódik, hogy tetszőleges $a>x_{1}$-re fennáll a következő:

$$
\begin{aligned}
a \int_{a}^{\infty}\left|f^{\prime}(x)\right| d x & =a \sum_{r=0}^{\infty} \int_{2^{r} a}^{2^{r+1} a}\left|f^{\prime}(x)\right| d x \leq C \sum_{r=0}^{\infty} \frac{1}{2^{r}} \sup _{b \geq B\left(2^{r} a\right)} \int_{b}^{2 b}|f(x)| d x \\
& \leq C \varepsilon \sum_{r=0}^{\infty} \frac{1}{2^{r}} \sup _{b \geq B\left(2^{j} a\right)} \int_{b}^{2 b} \frac{d x}{x} \leq C \varepsilon \ln 2 \sum_{r=0}^{\infty} \frac{1}{2^{r}} \leq(\ln 4 C) \varepsilon .
\end{aligned}
$$

Tehát (3.8) igaz. (3.1) egyenletes konvergenciája pedig a [10, Theorem 2] tétel (lásd 3.1.2. Tétel) első részének bizonyításának megismétlésével következik (3.8)-ból.

(ii) rész: Most azt tesszük fel, hogy $f: \mathbb{R}_{+} \rightarrow \overline{\mathbb{R}}_{+}$és (3.1) egyenletesen konvergens $t$-ben. Ekkor

$$
J_{b}(t):=\int_{b}^{2 b} f(x) \sin t x d x \rightarrow 0, \quad \text { ha } \quad b \rightarrow \infty,
$$

és az iménti konvergencia egyenletes $t$-ben. Így

$$
\sup _{b \geq a}\left(\sup _{t} J_{b}(t)\right) \rightarrow 0, \quad \text { ha } \quad a \rightarrow \infty .
$$


Legyen

$$
t(b):=\frac{\pi}{4 b}, \quad b>0 .
$$

Ekkor tetszőleges $b \leq x \leq 2 b$ esetén

$$
\frac{\pi}{4} \leq t(b) x \leq \frac{\pi}{2}
$$

és így

$$
\sin (t(b) x) \geq \sin \frac{\pi}{4}=\frac{1}{\sqrt{2}} .
$$

Az előző egyenlőtlenség felhasználásával adódik, hogy

$$
\begin{aligned}
I_{a} & =\sup _{b \geq a} \int_{b}^{2 b}|f(x)| d x \leq \sqrt{2} \sup _{b \geq a} \sin \frac{\pi}{4} \int_{b}^{2 b} f(x) d x \\
& \leq \sqrt{2} \sup _{b \geq a} \int_{b}^{2 b} f(x) \sin (t(b) x) d x \leq \sqrt{2} \sup _{b \geq a}\left(\sup _{t} J_{b}(t)\right)
\end{aligned}
$$

innen pedig (3.9) szerint

$$
I_{a} \rightarrow 0, \quad I_{B(a)} \rightarrow 0, \quad \text { ha } \quad a \rightarrow \infty .
$$

Végül, a (3.7) egyenlőtlenség alkalmazásával megkapjuk (3.3)-at.

\subsection{Formális deriválás és integrálás}

Tekintsük az

$$
\int_{0}^{\infty} x^{r} f(x) \sin t x d x
$$

szinuszintegrált, ahol $r$ egész szám. Az 1.4. alfejezethez hasonlóan, itt is csak a páros $r$-ekkel foglalkozunk, ekkor a (3.10) integrál pozitív $r$ esetén (3.1) $r$-szeres $t$-szerinti formális deriváltja, negatív $r$ esetén (3.1) $r$-szeres $t$-szerinti formális integrálja, az $r=0$ esetben pedig a (3.10) és a (3.1) integrálok megegyeznek. Az alfejezet eredményei [5]ben is olvashatók.

A nemnegatív, monoton nemnövő $f(x)$ függvények osztálya zárt az 1 / $x$-szel való szorzásra, viszont nem zárt az $x$-el való szorzásra, ellenben, mint azt a következő tétel $\operatorname{mutatja,} \operatorname{MVBVF}\left(\mathbb{R}_{+}\right)$mindkét műveletre zárt.

3.4.1. Tétel. Legyen $f(x) \in \operatorname{MVBVF}\left(\mathbb{R}_{+}\right)$. Ekkor tetszőleges rögzített $r$ egész szám esetén $g_{r}(x)=x^{r} f(x)$ szintén $\operatorname{MVBVF}\left(\mathbb{R}_{+}\right)$-beli. 
Bizonyítás. Legyen $f\left(x \operatorname{MVBVF}\left(\mathbb{R}_{+}\right)\right.$-beli a $C, A$ és $\lambda$ konstansokkal. A teljes indukció értelmében elegendő megmutatni, hogy $g_{1}(x)=x f(x) \in \operatorname{MVBVF}\left(\mathbb{R}_{+}\right)$és $g_{-1}(x)=$ $f(x) / x \in \operatorname{MVBVF}\left(\mathbb{R}_{+}\right)$. A (3.4) felhasználásával adódik, hogy bármely $a>A$ esetén

$$
\begin{aligned}
\int_{a}^{2 a}\left|g_{1}^{\prime}(x)\right| d x & \leq \int_{a}^{2 a}\left|x f^{\prime}(x)\right| d x+\int_{a}^{2 a}|f(x)| d x \leq 2 a \int_{a}^{2 a}\left|f^{\prime}(x)\right| d x+\frac{1}{a} \int_{a}^{2 a}|x f(x)| d x \\
& \leq 2 C \int_{a / \lambda}^{\lambda a}|f(x)| d x+\frac{1}{a} \int_{a}^{2 a}\left|g_{1}(x)\right| d x \leq \frac{2 C \lambda+1}{a} \int_{a / \lambda}^{\lambda a}\left|g_{1}(x)\right| d x,
\end{aligned}
$$

azaz $g_{1}$ teljesíti a (3.4) feltételt a $2 C \lambda+1, A$ és $\lambda$ konstansokkal. Hasonlóan,

$$
\begin{aligned}
\int_{a}^{2 a}\left|g_{-1}^{\prime}(x)\right| d x & \leq \int_{a}^{2 a} \frac{1}{x}\left|f^{\prime}(x)\right| d x+\int_{a}^{2 a} \frac{1}{x^{2}}|f(x)| d x \leq \frac{1}{a} \int_{a}^{2 a}\left|f^{\prime}(x)\right| d x+\frac{1}{a} \int_{a}^{2 a} \frac{1}{x}|f(x)| d x \\
& \leq \frac{C}{a^{2}} \int_{a / \lambda}^{\lambda a}|f(x)| d x+\frac{1}{a} \int_{a}^{2 a}\left|g_{-1}(x)\right| d x \leq \frac{C \lambda+1}{a} \int_{a / \lambda}^{\lambda a}\left|g_{-1}(x)\right| d x,
\end{aligned}
$$

tehát $g_{-1}$ is $\operatorname{MVBVF}\left(\mathbb{R}_{+}\right)$-beli a $C \lambda+1, A$ és $\lambda$ konstansokkal.

Az iménti tétel és a 3.1.2. Tétel összevetéséből következik

3.4.2. Következmény. Tegyük fel, hogy $f(x) \in \operatorname{MVBVF}\left(\mathbb{R}_{+}\right)$, (3.2) fennáll és $r$ pozitív páros szám.

(i) Ha $f: \mathbb{R}_{+} \rightarrow \mathbb{C}$ és $x^{r+1} f(x) \rightarrow 0$, ha $x \rightarrow \infty$, akkor a (3.10) szinuszintegrál egyenletesen konvergens $t$-ben.

(ii) Megfordítva, ha $f: \mathbb{R}_{+} \rightarrow \overline{\mathbb{R}}_{+}$és a (3.10) integrál konvergenciája egyenletes $t$-ben, akkor $x^{r+1} f(x) \rightarrow 0$, ha $x \rightarrow \infty$.

Az iménti állítások igazak maradnak akkor is, ha r negatív páros szám és $x^{r+1} f(x) \in$ $L_{\text {loc }}^{1}\left(\overline{\mathbb{R}}_{+}\right)$.

Az $\operatorname{SBVF}\left(\mathbb{R}_{+}\right)$függvényosztályra a 3.4.1. Tétel fele igaz.

3.4.3. Tétel. Tegyük fel, hogy $f(x) \in \mathrm{SBVF}\left(\mathbb{R}_{+}\right)$. Ekkor tetszöleges rögzített $r$ pozitív egész szám esetén $g_{r}(x)=x^{r} f(x) \in \operatorname{SBVF}\left(\mathbb{R}_{+}\right)$.

Bizonyítás. Legyen $f\left(x \operatorname{SBVF}\left(\mathbb{R}_{+}\right)\right.$-beli a $C, A$ és $\lambda$ konstansokkal. Elegendő megmutatni, hogy $g_{1}(x)=x f(x) \in \operatorname{SBVF}\left(\mathbb{R}_{+}\right)$. A (3.5) alkalmazásával adódik, hogy bármely $a>A$ esetén

$$
\int_{a}^{2 a}\left|g_{1}^{\prime}(x)\right| d x \leq 2 a \int_{a}^{2 a}\left|f^{\prime}(x)\right| d x+\frac{1}{a} \int_{a}^{2 a}|x f(x)| d x
$$




$$
\begin{aligned}
& \leq 2 C \sup _{b \geq a / \lambda} \int_{b}^{2 b}|f(x)| d x+\frac{1}{a} \int_{a}^{2 a}\left|g_{1}(x)\right| d x \\
& \leq \frac{2 C \lambda+1}{a} \sup _{b \geq a / \lambda} \int_{b}^{2 b}\left|g_{1}(x)\right| d x
\end{aligned}
$$

azaz $g_{1}$ teljesíti a (3.5) feltételt a $2 C \lambda+1, A$ és $\lambda$ konstansokkal.

A fenti tétel és a 3.2.3. Tételt összevetve adódik

3.4.4. Következmény. $H a f(x) \in \operatorname{SBVF}\left(\mathbb{R}_{+}\right)$, (3.2) fennáll és $r$ pozitív páros szám, akkor a 3.4.2. Következmény (i) és (ii) állításai fennállnak.

Meggondolható, hogy $\mathrm{SBVF}_{2}\left(\mathbb{R}_{+}\right)$nem zárt sem az $1 / x$-szel, sem az $x$-el való szorzásra. 


\section{4. fejezet}

\section{Kettős szinuszintegrálok}

\subsection{Kettős integrálok konvergenciája}

Tekintsük az

$$
\int_{0}^{\infty} \int_{0}^{\infty} f(x, y) \sin u x \sin v y d x d y, \quad(u, v) \in \mathbb{R}^{2}
$$

alakú kettős szinuszintegrálokat, ahol $f(x, y): \mathbb{R}_{+}^{2} \rightarrow \mathbb{C}$ Lebesgue-mérhető függvény. Az általánosság megszorítása nélkül feltehetjük, hogy $(u, v) \in \mathbb{R}_{+}^{2}$, hiszen a szinusz függvény páratlan, és a 0 helyen 0 értéket vesz fel. A fejezet célja annak megállapítása ill. igazolása, hogy a (4.1) integrál reguláris konvergenciájának milyen szükséges és elegendő feltételei vannak.

Mielőtt a reguláris konvergenciát definiáljuk, tekintsük a Pringsheim-féle konvergencia fogalmát. Ezen konvergencia a diszkrét esethez (lásd 2.1. alfejezet) hasonlóan definiált. Legyen $\Phi: \overline{\mathbb{R}}_{+}^{2} \rightarrow \mathbb{C}$, melyre $\Phi \in L_{\text {loc }}^{1}\left(\overline{\mathbb{R}}_{+}^{2}\right)$. Azt mondjuk, hogy az

$$
\int_{0}^{\infty} \int_{0}^{\infty} \Phi(x, y) d x d y
$$

kettős integrál Pringsheim értelemben konvergens, ha az

$$
I_{\Phi}\left(0, b_{1} ; 0, b_{2}\right):=\int_{0}^{b_{1}} \int_{0}^{b_{2}} \Phi(x, y) d x d y
$$

integráloknak létezik véges határértéke, ha $b_{1}, b_{2} \rightarrow \infty$ ( $b_{1}$ és $b_{2}$ egymástól függetlenül tart a végtelenbe). A Cauchy-féle konvergencia kritérium következtében (4.2) Pringsheim értelemben konvergens akkor és csak akkor, ha bármely $\varepsilon>0$-hoz létezik olyan $b_{0}=b_{0}(\varepsilon)$ küszöbszám, melyre

$$
\left|I_{\Phi}\left(0, b_{1} ; 0, b_{2}\right)-I_{\Phi}\left(0, b_{3} ; 0, b_{4}\right)\right| \leq \varepsilon, \quad \text { ha } \min \left\{b_{1}, b_{2}, b_{3}, b_{4}\right\}>b_{0} .
$$


A Pringsheim-konvergencia maga után vonja az alábbi maradékintegrálokra vonatkozó konvergenciát:

$$
\begin{array}{r}
I_{\Phi}\left(a_{1}, b_{1} ; a_{2}, b_{2}\right)=I_{\Phi}\left(0, b_{1} ; 0, b_{2}\right)-I_{\Phi}\left(0, a_{1} ; 0, b_{2}\right)-I_{\Phi}\left(0, b_{1} ; 0, a_{2}\right)+I_{\Phi}\left(0, a_{1} ; 0, a_{2}\right) \rightarrow 0 \\
\text { ha } \min \left\{a_{1}, a_{2}\right\} \rightarrow \infty, b_{1}>a_{1}>0, b_{2}>a_{2}>0 .
\end{array}
$$

A reguláris konvergenciát a maradékintegrálokkal definiáljuk: a (4.2) integrál regulárisan konvergens akkor, ha

$$
I_{\Phi}\left(a_{1}, b_{1} ; a_{2}, b_{2}\right) \rightarrow 0, \quad \text { ha } a_{1}+a_{2} \rightarrow \infty, b_{1}>a_{1} \geq 0, b_{2}>a_{2} \geq 0 .
$$

Az iménti feltétel ekvivalens azzal, hogy az alábbi két feltétel mindegyike teljesül:

$$
I_{\Phi}\left(a_{1}, b_{1} ; 0, b_{2}\right) \rightarrow 0, \quad \text { ha } b_{1}>a_{1} \rightarrow \infty \text {, és } b_{2}>0 \text { tetszőleges }
$$

és

$$
I_{\Phi}\left(0, b_{1} ; a_{2}, b_{2}\right) \rightarrow 0, \quad \text { ha } b_{2}>a_{2} \rightarrow \infty \text {, és } b_{1}>0 \text { tetszőleges. }
$$

Az előző ekvivalens átírásból látszik, hogy a reguláris konvergencia maga után vonja a Pringsheim-féle konvergenciát, hiszen

$$
\begin{aligned}
I_{\Phi}\left(0, b_{1} ; 0, b_{2}\right)-I_{\Phi}\left(0, b_{3} ; 0, b_{4}\right)= & I_{\Phi}\left(\min \left\{b_{1}, b_{3}\right\}, \max \left\{b_{1}, b_{3}\right\} ; 0, \min \left\{b_{2}, b_{4}\right)\right\} \\
& +I_{\Phi}\left(0, \min \left\{b_{1}, b_{3}\right\} ; \min \left\{b_{2}, b_{4}\right\}, \max \left\{b_{2}, b_{4}\right\}\right) .
\end{aligned}
$$

Ellenben nem minden Pringsheim értelemben konvergens kettős integrál regulárisan konvergens, erre példa olvasható [8]-ban.

Visszatérve a (4.1) kettős szinuszintegrálra, ahhoz, hogy az

$$
I_{f}\left(a_{1}, b_{1} ; a_{2}, b_{2} ; u, v\right):=\int_{a_{1}}^{b_{1}} \int_{a_{2}}^{b_{2}} f(x, y) \sin u x \sin v y d x d y
$$

részletintegrálok létezzenek bármely $b_{1}>a_{1} \geq 0, b_{2}>a_{2} \geq 0$ és $(u, v) \in \mathbb{R}_{+}^{2}$ esetén, a továbbiakban feltesszük, hogy

$$
x y f(x, y) \in L_{\mathrm{loc}}^{1}\left(\overline{\mathbb{R}}_{+}^{2}\right) .
$$

Ekkor ugyanis bármely $\left(b_{1}, b_{2}\right) \in \mathbb{R}_{+}^{2}$ esetén az alábbi improprius integrálok léteznek, és véges értéket vesznek fel:

$$
\int_{0}^{b_{1}} \int_{0}^{b_{2}} x y|f(x, y)| d x d y<\infty
$$


A (4.3) feltétel egyben azt is biztosítja, hogy $f(x) \in L_{\text {loc }}^{1}\left(\mathbb{R}_{+}^{2}\right)$, mivel

$$
\int_{a_{1}}^{b_{1}} \int_{a_{2}}^{b_{2}}|f(x, y)| d x d y \leq \frac{1}{a_{1} a_{2}} \int_{a_{1}}^{b_{1}} \int_{a_{2}}^{b_{2}} x y|f(x, y)|<\infty
$$

bármely $b_{1}>a_{1}>0, b_{2}>a_{2}>0$ esetén.

\section{2. Új eredmények}

A továbbiakban az $f(x, y): \mathbb{R}_{+}^{2} \rightarrow \mathbb{C}$ függvényről feltesszük, hogy lokálisan abszolút folytonos $\mathbb{R}_{+}^{2}$-en, jelölésben $f(x, y) \in \mathrm{AC}_{\text {loc }}\left(\mathbb{R}_{+}^{2}\right)$, ami alatt azt értjük, hogy az $f_{x}(x, y):=$ $\partial f(x, y) / \partial x$ és az $f_{y}(x, y):=\partial f(x, y) / \partial y$ parciális deriváltak léteznek $\mathbb{R}_{+}^{2}$-en mindenütt,

$$
\begin{aligned}
& \int_{a_{1}}^{b_{1}} f_{x}(x, y) d x=f\left(b_{1}, y\right)-f\left(a_{1}, y\right), \quad b_{1}>a_{1}>0, y>0, \\
& \int_{a_{2}}^{b_{2}} f_{y}(x, y) d y=f\left(x, b_{2}\right)-f\left(x, a_{2}\right), \quad b_{2}>a_{2}>0, x>0,
\end{aligned}
$$

továbbá az $f_{x y}(x, y)$ és $f_{y x}(x, y)$ vegyes parciális deriváltak léteznek, $f_{x y}=f_{y x} \mathbb{R}_{+}^{2}$-en majdnem mindenütt, és

$$
\begin{array}{ll}
\int_{a_{1}}^{b_{1}} f_{x y}(x, y) d x=f_{y}\left(b_{1}, y\right)-f_{y}\left(a_{1}, y\right), & b_{1}>a_{1}>0, y>0, \\
\int_{a_{2}}^{b_{2}} f_{x y}(x, y) d y=f_{x}\left(x, b_{2}\right)-f_{x}\left(x, a_{2}\right), & b_{2}>a_{2}>0, x>0 .
\end{array}
$$

Ekkor a vegyes parciális deriváltak és az $f$ függvény között fennáll az

$$
\int_{a_{1}}^{b_{1}} \int_{a_{2}}^{b_{2}} f_{x y}(x, y) d x d y=f\left(b_{1}, b_{2}\right)-f\left(a_{1}, b_{2}\right)-f\left(b_{1}, a_{2}\right)+f\left(a_{1}, a_{2}\right)
$$

összefüggés $\left(b_{1}>a_{1}>0, b_{2}>a_{2}>0\right)$.

A következő függvényosztályok az $\operatorname{NBVF}\left(\mathbb{R}_{+}\right)$és $\operatorname{MVBVF}\left(\mathbb{R}_{+}\right)$osztályok kétdimenziós megfelelői:

Definíció. Azt mondjuk, hogy az $f(x, y) \in \mathrm{AC}_{\text {loc }}\left(\mathbb{R}_{+}^{2}\right)$ függvény $\operatorname{NBVF}\left(\mathbb{R}_{+}^{2}\right)$-beli, ha létezik olyan, csak $f$-től függő, $C$ konstans, melyre

$$
\int_{a_{1}}^{2 a_{1}}\left|f_{x}(x, y)\right| d x \leq C\left(\left|f\left(a_{1}, y\right)\right|+\left|f\left(2 a_{1}, y\right)\right|\right), \quad a_{1}, y>0,
$$




$$
\begin{gathered}
\int_{a_{2}}^{2 a_{2}}\left|f_{y}(x, y)\right| d y \leq C\left(\left|f\left(x, a_{2}\right)\right|+\left|f\left(x, 2 a_{2}\right)\right|\right), \quad x, a_{2}>0, \\
\int_{a_{1}}^{2 a_{1}} \int_{a_{2}}^{2 a_{2}}\left|f_{x y}(x, y)\right| d x d y \leq C\left(\left|f\left(a_{1}, a_{2}\right)\right|+\left|f\left(a_{1}, 2 a_{2}\right)\right|\right. \\
\left.+\left|f\left(2 a_{1}, a_{2}\right)\right|+\left|f\left(2 a_{1}, 2 a_{2}\right)\right|\right), \quad a_{1}, a_{2}>0 .
\end{gathered}
$$

Definíció. Az $f(x, y) \in \mathrm{AC}_{\text {loc }}\left(\mathbb{R}_{+}^{2}\right)$ függvényt $\operatorname{MVBVF}\left(\mathbb{R}_{+}^{2}\right)$-belinek nevezzük, ha léteznek olyan, csak $f$-től függő, $C$ és $\lambda \geq 2$ konstansok, amelyekre

$$
\begin{gathered}
\int_{a_{1}}^{2 a_{1}}\left|f_{x}(x, y)\right| d x \leq \frac{C}{a_{1}} \int_{a_{1} / \lambda}^{\lambda a_{1}}|f(x, y)| d x, \quad a_{1}, y>0, \\
\int_{a_{2}}^{2 a_{2}}\left|f_{y}(x, y)\right| d y \leq \frac{C}{a_{2}} \int_{a_{2} / \lambda}^{\lambda a_{2}}|f(x, y)| d y, \quad x, a_{2}>0, \\
\int_{a_{1}}^{2 a_{1}} \int_{a_{2}}^{2 a_{2}}\left|f_{x y}(x, y)\right| d x d y \leq \frac{C}{a_{1} a_{2}} \int_{a_{1} / \lambda}^{\lambda a_{1}} \int_{a_{2} / \lambda}^{\lambda a_{2}}|f(x, y)| d x d y, \quad a_{1}, a_{2}>0 .
\end{gathered}
$$

4.2.1. Tétel. $\operatorname{MVBVF}\left(\mathbb{R}_{+}^{2}\right) \supsetneqq \operatorname{NBVF}\left(\mathbb{R}_{+}^{2}\right)$.

4.2.2. Tétel. Legyen $f \in \operatorname{MVBVF}\left(\mathbb{R}_{+}^{2}\right)$ olyan függvény, amelyre (4.3) fennáll.

(i) $\mathrm{Haf}: \mathbb{R}_{+}^{2} \rightarrow \mathbb{C}$ és

$$
x y f(x, y) \rightarrow 0, \quad \text { ha } \quad x+y \rightarrow \infty,
$$

akkor a (4.1) integrál reguláris konvergenciája egyenletes $(u, v) \in \mathbb{R}_{+}^{2}$-ben.

(ii) Megforditva, ha $f: \mathbb{R}_{+}^{2} \rightarrow \overline{\mathbb{R}}_{+}$és a (4.1) reguláris konvergenciája egyenletes $(u, v) \in \mathbb{R}_{+}^{2}$ ben, akkor (4.10) fennáll.

Az előző tétel ill. az alábbi következmény egyaránt kis eltéréssel olvasható [8]-ban, mivel az ott bebizonyított tételek tartalmaznak egy olyan plusz feltételt, mely elhagyható, amint az az itteni bizonyításból kiderül.

4.2.3. Következmény. Ha $f: \mathbb{R}_{+} \rightarrow \overline{\mathbb{R}}_{+} \operatorname{MVBVF}\left(\mathbb{R}_{+}^{2}\right)$-beli, akkor (4.10) szükséges és elegendö feltétele annak, hogy (4.1) egyenletesen konvergens legyen $(u, v)$-ben.

A monotonitást két dimenzióban többféle módon is szokás definiálni. A fejezetben során az $f: \mathbb{R}_{+}^{2} \rightarrow \mathbb{R}_{+}$függvényt akkor nevezzük monoton nemnövőnek, ha mindkét változójában monoton nemnövő, és

$$
f\left(x_{1}, y_{1}\right)-f\left(x_{2}, y_{1}\right)-f\left(x_{1}, y_{2}\right)+f\left(x_{2}, y_{2}\right) \geq 0,
$$


ha $x_{2}>x_{1}>0, y_{2}>y_{1}>0$. Világos, hogy ha $f: \mathbb{R}_{+}^{2} \rightarrow \overline{\mathbb{R}}_{+}$és $f \in \mathrm{AC}_{\text {loc }}\left(\mathbb{R}_{+}^{2}\right)$, akkor $f$ pontosan akkor monoton nemnövő, ha

$$
f_{x}(x, y) \leq 0, \quad f_{y}(x, y) \leq 0 \quad \text { és } \quad f_{x y}(x, y) \geq 0 \quad \text { majdnem mindenütt, }
$$

ezen feltételek pedig maguk után vonják a (4.4)-(4.6) feltételeket, azaz az $\mathbb{R}_{+}^{2}$-en értelmezett, nemnegatív, lokálisan abszolút folytonos, monoton nemcsökkenő függvények $\operatorname{NBVF}\left(\mathbb{R}_{+}^{2}\right)$-beliek, ezáltal MVBVF $\left(\mathbb{R}_{+}^{2}\right)$-beliek.

4.2.4. Következmény. Ha $f: \mathbb{R}_{+}^{2} \rightarrow \overline{\mathbb{R}}_{+}$monoton nemnövő és $f \in \mathrm{AC}_{\text {loc }}\left(\mathbb{R}_{+}^{2}\right)$, akkor (4.10) szükséges és elegendö feltétele annak, hogy (4.1) egyenletesen konvergens legyen $(u, v)$ ben.

Megjegyezzük, hogy hasonló állítást láttak be [11]-ben az $f: \mathbb{R}_{+}^{2} \rightarrow \overline{\mathbb{R}}_{+}$monoton nemnövő, nem feltétlenül lokálisan abszolút folytonos függvényekre is.

\subsection{Segédállítások}

4.3.1. Lemma. Tegyükfel, hogy $g: \mathbb{R}_{+} \rightarrow \mathbb{C}, g \in \mathrm{AC}_{\text {loc }}\left(\mathbb{R}_{+}\right)$és $x g(x) \in L_{\text {loc }}^{1}\left(\overline{\mathbb{R}}_{+}\right)$. Ha létezik olyan C konstans, melyre bármely $a>0$ esetén

$$
\int_{a}^{2 a}\left|g^{\prime}(x)\right| d x \leq C(|g(a)|+|g(2 a)|),
$$

akkor tetszőleges $a>0-r a$

$$
\int_{a}^{2 a}\left|g^{\prime}(x)\right| d x \leq \frac{4 C}{a} \int_{a / 4}^{4 a}|g(x)| d x .
$$

A 4.3.1. Lemma azonnal következik a [10, Theorem 3] bizonyításából.

4.3.2. Lemma. Legyen $f: \mathbb{R}_{+}^{2} \rightarrow \mathbb{C}, f \in \operatorname{MVBVF}\left(\mathbb{R}_{+}^{2}\right)$ olyan függvény, mely teljesíti (4.3)at. Ha (4.10) fennáll, akkor

$$
\begin{gathered}
a_{1} y \int_{a_{1}}^{\infty}\left|f_{x}(x, y)\right| d x \rightarrow 0, \text { ha } a_{1}+y \rightarrow \infty, a_{1}, y>0, \\
x a_{2} \int_{a_{2}}^{\infty}\left|f_{y}(x, y)\right| d y \rightarrow 0, \text { ha } x+a_{2} \rightarrow \infty, x, a_{2}>0, \\
a_{1} a_{2} \int_{a_{1}}^{\infty} \int_{a_{2}}^{\infty}\left|f_{x y}(x, y)\right| d x d y \rightarrow 0, \text { ha } a_{1}+a_{2} \rightarrow \infty, a_{1}, a_{2}>0 .
\end{gathered}
$$


Bizonyítás. Legyen $\varepsilon>0$ tetszőleges, rögzített, valamint a $C, \lambda$ konstansok az $f$-hez tartozó MVBVF( $\left.\mathbb{R}_{+}^{2}\right)$ definícióbeli számok. A (4.10) feltételből következik, hogy létezik olyan $x_{1}>0$ küszöbszám, melyre

$$
x y|f(x, y)| \leq \varepsilon, \quad \text { ha } \quad x+y>x_{1} .
$$

(4.11) igazolásához tekintsünk olyan tetszőleges, rögzített $a_{1}, y$ számokat, melyekre $a_{1}+y>\lambda x_{1}$. Ekkor (4.7) és (4.14) használatával becsüljünk a következő módon:

$$
\begin{aligned}
a_{1} y \int_{a_{1}}^{\infty}\left|f_{x}(x, y)\right| d x & =a_{1} y \sum_{r=0}^{\infty} \int_{2^{r} a_{1}}^{2^{r+1} a_{1}}\left|f_{x}(x, y)\right| d x \leq a_{1} y \sum_{r=0}^{\infty} \frac{C}{2^{r} a_{1}} \int_{2^{r} a_{1} / \lambda}^{\lambda 2^{r} a_{1}}|f(x, y)| d x \\
& \leq C \sum_{r=0}^{\infty} \frac{1}{2^{r}} \int_{2^{r} a_{1} / \lambda}^{\lambda 2^{r} a_{1}} \frac{\varepsilon}{x} d x=C \varepsilon \ln \left(\lambda^{2}\right) \sum_{r=0}^{\infty} \frac{1}{2^{r}}=(4 C \ln \lambda) \varepsilon,
\end{aligned}
$$

amiből következik (4.11).

(4.12) hasonlóan bizonyítható, a (4.7) feltétel helyett (4.8)-at alkalmazva.

Végül, (4.13) igazolásához, legyen $a_{1}+a_{2}>\lambda x_{1}$. Ekkor a (4.9) és (4.14) egyenlőtlenségeket figyelembe véve adódik, hogy

$$
\begin{aligned}
& a_{1} a_{2} \int_{a_{1}}^{\infty} \int_{a_{2}}^{\infty}\left|f_{x y}(x, y)\right| d x d y=a_{1} a_{2} \sum_{r=0}^{\infty} \sum_{s=0}^{\infty} \int_{2^{r} a_{1}}^{2^{r+1}} \int_{2^{s} a_{2}}^{a_{1}{ }^{s+1} a_{2}}\left|f_{x y}(x, y)\right| d x d y \\
& \leq \sum_{r=0}^{\infty} \sum_{s=0}^{\infty} \frac{C}{2^{r+s}} \int_{2^{r} a_{1} / \lambda}^{\lambda 2^{r} a_{1}} \int_{2^{s}}^{\lambda 2^{s} a_{2} / \lambda}|f(x, y)| d x d y \\
& \leq C \sum_{r=0}^{\infty} \sum_{s=0}^{\infty} \frac{1}{2^{r+s}} \int_{2^{r}}^{\lambda 2_{1}^{r} / \lambda} \int_{2^{s} a_{a_{2} / \lambda}}^{\lambda 2^{s} a_{2}} \frac{\varepsilon}{x y} d x d y \\
& =C \varepsilon \ln ^{2}\left(\lambda^{2}\right) \sum_{r=0}^{\infty} \sum_{s=0}^{\infty} \frac{1}{2^{r+s}}=\left(16 C \ln ^{2} \lambda\right) \varepsilon \text {, }
\end{aligned}
$$

ami biztosítja (4.13) igaz voltát.

4.3.3. Lemma. Tegyük fel, hogy $f: \mathbb{R}_{+}^{2} \rightarrow \overline{\mathbb{R}}_{+}, f \in \operatorname{MVBVF}\left(\mathbb{R}_{+}^{2}\right)$ a $C, \lambda$ konstansokkal. Ekkor tetszöleges $a_{1}, a_{2}>0$ esetén

$$
a_{1} a_{2} f\left(a_{1}, a_{2}\right) \leq(3 C+1) \int_{a_{1} / \lambda}^{\lambda a_{1}} \int_{a_{2} / \lambda}^{\lambda a_{2}} f(x, y) d x d y .
$$

Bizonyítás. Mivel $f \in \mathrm{AC}_{\text {loc }}\left(\mathbb{R}_{+}^{2}\right)$, ezért bármely $a_{1} \leq s \leq 2 a_{1}$ és $a_{2} \leq t \leq 2 a_{2}$ esetén

$$
f\left(a_{1}, a_{2}\right)-f\left(a_{1}, t\right)-f\left(s, a_{2}\right)+f(s, t)=\int_{a_{1}}^{s} \int_{a_{2}}^{t} f_{x y}(x, y) d x d y,
$$


továbbá

$$
f(s, t)-f\left(a_{1}, t\right)=\int_{a_{1}}^{s} f_{x}(x, t) d x
$$

és

$$
f(s, t)-f\left(s, a_{2}\right)=\int_{a_{2}}^{t} f_{y}(s, y) d y .
$$

Az előző egyenlőségek és a (4.7)-(4.9) egyenlőtlenségek felhasználásával kapjuk, hogy $a_{1} \leq s \leq 2 a_{1}$ és $a_{2} \leq t \leq 2 a_{2}$-re

$$
\begin{aligned}
f\left(a_{1}, a_{2}\right) & =\left(f\left(a_{1}, t\right)-f(s, t)\right)+\left(f\left(s, a_{2}\right)-f(s, t)\right)+f(s, t)+\int_{a_{1}}^{s} \int_{a_{2}}^{t} f_{x y}(x, y) d x d y \\
& =f(s, t)-\int_{a_{1}}^{s} f_{x}(x, t) d x-\int_{a_{2}}^{t} f_{y}(s, y) d y+\int_{a_{1}}^{s} \int_{a_{2}}^{t} f_{x y}(x, y) d x d y \\
& \leq f(s, t)+\int_{a_{1}}^{s}\left|f_{x}(x, t)\right| d x+\int_{a_{2}}^{t}\left|f_{y}(s, y)\right| d y+\int_{a_{1}}^{s} \int_{a_{2}}^{t}\left|f_{x y}(x, y)\right| d x d y \\
& \leq f(s, t)+\int_{a_{1}}^{2 a_{1}}\left|f_{x}(x, t)\right| d x+\int_{a_{2}}^{2 a_{2}}\left|f_{y}(s, y)\right| d y+\int_{a_{1}}^{2 a_{2}} \int_{a_{2}}^{\lambda}\left|f_{x y}(x, y)\right| d x d y \\
& \leq f(s, t)+\frac{C}{a_{1}} \int_{a_{1} / \lambda}^{\lambda a_{1}} f(x, t) d x+\frac{C}{a_{2}} \int_{a_{2} / \lambda}^{\lambda a_{2}} f(s, y) d y+\frac{C_{1}}{a_{1} a_{2}} \int_{a_{1} / \lambda a_{2}}^{\int_{a_{2} / \lambda}} f(x, y) d x d y .
\end{aligned}
$$

A legutoljára kapott becslés bal oldalát, $f\left(a_{1}, a_{2}\right)$-t, valamint jobb oldalát integráljuk $s$ és $t$ szerint az $\left[a_{1}, 2 a_{1}\right] \times\left[a_{2}, 2 a_{2}\right]$ téglalapon, ekkor

$$
\begin{aligned}
a_{1} a_{2} f\left(a_{1}, a_{2}\right) \leq & \int_{a_{1}}^{2 a_{1}} \int_{a_{2}}^{2 a_{2}} f(s, t) d s d t+C \int_{a_{1} / \lambda}^{\lambda a_{1}} \int_{a_{2}}^{2 a_{2}} f(x, t) d x d t \\
& +C \int_{a_{1}}^{2 a_{1}} \int_{a_{2} / \lambda}^{\lambda a_{2}} f(s, y) d s d y+C \int_{a_{1} / \lambda}^{\lambda a_{1}} \int_{a_{2} / \lambda}^{\lambda a_{2}} f(x, y) d x d y \\
\leq & (3 C+1) \int_{a_{1} / \lambda}^{\lambda a_{1}} \int_{a_{2} / \lambda}^{\lambda a_{2}} f(x, y) d x d y,
\end{aligned}
$$

amiből következik (4.15), hiszen $\lambda \geq 2$.

\subsection{A 4.2.1. és 4.2 .2 . Tételek bizonyítása}

A 4.2.1. Tétel bizonyítása. Először bebizonyítjuk, hogy $\operatorname{MVBVF}\left(\mathbb{R}_{+}^{2}\right) \supset \operatorname{NBVF}\left(\mathbb{R}_{+}^{2}\right)$. Legyen $f(x, y) \in \operatorname{NBVF}\left(\mathbb{R}_{+}^{2}\right)$ a $C, A$ konstansokkal. Mivel $f(x, y) \in \mathrm{AC}_{\text {loc }}\left(\mathbb{R}_{+}^{2}\right)$, ezért tetszőle- 
ges $y>0$ esetén $g(x):=f(x, y) \in \mathrm{AC}_{\text {loc }}\left(\mathbb{R}_{+}\right)$és tetszőleges $x>0$ esetén $g(y):=f(x, y) \in$ $\mathrm{AC}_{\text {loc }}\left(\mathbb{R}_{+}\right)$, így a (4.4) és (4.5) feltételek teljesülése miatt alkalmazhatjuk a 4.3.1. Lemmát, amiből (4.7) és (4.8) azonnal adódik $C$ helyett $4 C$-vel és a $\lambda=4$ konstanssal. Be kell még látnunk továbbá, hogy (4.9) fennáll. (4.6) alkalmazásával adódik, hogy tetszőleges $a_{1}, a_{2}$ pozitív számokra

$$
\begin{aligned}
& J:=\int_{3 a_{1} / 2}^{2 a_{1}} \int_{3 a_{2} / 2}^{2 a_{2}}\left(\int_{s / 2}^{2 s} \int_{t / 2}^{2 t}\left|f_{x y}(x, y)\right| d x d y\right) d s d t \\
& =\int_{3 a_{1} / 2}^{2 a_{1}} \int_{3 a_{2} / 2}^{2 a_{2}}\left(\left\{\int_{s / 2}^{s} \int_{t / 2}^{t}+\int_{s / 2}^{s} \int_{t}^{2 t}+\int_{s}^{2 s} \int_{t / 2}^{t}+\int_{s}^{2 s} \int_{t}^{2 t}\right\}\left|f_{x y}(x, y)\right| d x d y\right) d s d t \\
& \leq C \int_{3 a_{1} / 2}^{2 a_{1}} \int_{3 a_{2} / 2}^{2 a_{2}}(|f(s / 2, t / 2)|+2|f(s / 2, t)|+|f(s / 2,2 t)|+2|f(s, t / 2)|+4|f(s, t)| \\
& +2|f(s, 2 t)|+|f(2 s, t / 2)|+2|f(2 s, t)|+|f(2 s, 2 t)|) d s d t \\
& =C\left\{4 \int_{3 a_{1} / 4}^{a_{1}} \int_{3 a_{2} / 4}^{a_{2}}+4 \int_{3 a_{1} / 4}^{a_{1}} \int_{3 a_{2} / 2}^{2 a_{2}}+\int_{3 a_{1} / 4}^{a_{1}} \int_{3 a_{2}}^{4 a_{2}}+4 \int_{3 a_{1} / 2}^{2 a_{1}} \int_{3 a_{2} / 4}^{a_{2}}+4 \int_{3 a_{1} / 2}^{2 a_{1}} \int_{3 a_{2} / 2}^{2 a_{2}}\right. \\
& \left.+\int_{3 a_{1} / 2}^{2 a_{1}} \int_{3 a_{2}}^{4 a_{2}}+\int_{3 a_{1}}^{4 a_{1}} \int_{3 a_{2} / 4}^{a_{2}}+\int_{3 a_{1}}^{4 a_{1}} \int_{3 a_{2} / 2}^{2 a_{2}}+\frac{1}{4} \int_{3 a_{1}}^{4 a_{1}} \int_{3 a_{2}}^{4 a_{2}}\right\}|f(s, t)| d s d t \\
& \leq 4 C \int_{3 a_{1} / 4}^{4 a_{1}} \int_{3 a_{2} / 4}^{4 a_{2}}|f(s, t)| d s d t .
\end{aligned}
$$

Másrészről, ha $3 a_{1} / 2 \leq s \leq 2 a_{1}$ és $3 a_{2} / 2 \leq t \leq 2 a_{2}$, akkor $[s / 2,2 s] \supset\left[a_{1}, 2 a_{1}\right]$ és $[t / 2,2 t] \supset\left[a_{2}, 2 a_{2}\right]$, így

$$
J \geq \int_{3 a_{1} / 2}^{2 a_{1}} \int_{3 a_{2} / 2}^{2 a_{2}}\left(\int_{a_{1}}^{2 a_{1}} \int_{a_{2}}^{2 a_{2}}\left|f_{x y}(x, y)\right| d x d y\right) d s d t=\frac{a_{1} a_{2}}{4} \int_{a_{1}}^{2 a_{1}} \int_{a_{2}}^{2 a_{2}}\left|f_{x y}(x, y)\right| d x d y .
$$

A fenti egyenlőtlenségekből következik, hogy

$$
\frac{a_{1} a_{2}}{4} \int_{a_{1}}^{2 a_{1}} \int_{a_{2}}^{2 a_{2}}\left|f_{x y}(x, y)\right| d x d y \leq 4 C \int_{3 a_{1} / 4}^{4 a_{1}} \int_{3 a_{2} / 4}^{4 a_{2}}|f(s, t)| d s d t
$$

innen

$$
\int_{a_{1}}^{2 a_{1}} \int_{a_{2}}^{2 a_{2}}\left|f_{x y}(x, y)\right| d x d y \leq \frac{16 C}{a_{1} a_{2}} \int_{a_{1} / 4}^{4 a_{1}} \int_{a_{2} / 4}^{4 a_{2}}|f(s, t)| d s d t .
$$

Tehát a (4.7)-(4.9) feltételek teljesülnek a 16C és $\lambda=4$ konstansokkal. Tehát $f(x, y) \in$ $\operatorname{MVBVF}\left(\mathbb{R}_{+}^{2}\right)$, azaz $\operatorname{MVBVF}\left(\mathbb{R}_{+}^{2}\right) \supseteq \operatorname{NBVF}\left(\mathbb{R}_{+}^{2}\right)$. 
Ezután megadunk egy olyan példafüggvényt, mely $\operatorname{MVBVF}\left(\mathbb{R}_{+}^{2}\right) \backslash \operatorname{NBVF}\left(\mathbb{R}_{+}^{2}\right)$-beli. Legyen

$$
G(x, y)=g(x) g(y), \quad(x, y) \in \mathbb{R}_{+}^{2},
$$

ahol $g$ a következő:

$$
g(x)=\frac{1}{1+x} \sin \left(\frac{\pi}{\ln 2} \ln x\right), \quad x \in \mathbb{R}_{+} .
$$

Könnyen látható, hogy $g(x)$ folytonos, $g(x) \rightarrow 0$, ha $x \rightarrow \infty, x g(x) \in L_{\text {loc }}^{1}\left(\overline{\mathbb{R}}_{+}\right)$, továbbá

$$
g^{\prime}(x)=\frac{\pi}{\ln 2} \frac{1}{x(1+x)} \cos \left(\frac{\pi}{\ln 2} \ln x\right)-\frac{1}{(1+x)^{2}} \sin \left(\frac{\pi}{\ln 2} \ln x\right),
$$

$\operatorname{azaz} g(x) \in \mathrm{AC}_{\text {loc }}\left(\mathbb{R}_{+}\right) \cdot g(x) \notin \mathrm{NBVF}\left(\mathbb{R}_{+}\right)$, mivel

$$
g\left(2^{k}\right)=\frac{1}{1+2^{k}} \sin k \pi=0, \quad k \in \mathbb{Z},
$$

viszont $g^{\prime}$-nek nincs más pontban zérushelye, így

$$
\int_{2^{k}}^{2^{k+1}}\left|g^{\prime}(x)\right| d x>0, \quad k \in \mathbb{Z} .
$$

Ellenben bármely $a>0$ esetén

$$
\begin{aligned}
\int_{a}^{2 a}\left|g^{\prime}(x)\right| d x & \leq \frac{\pi}{\ln 2} \frac{1}{a} \int_{a}^{2 a} \frac{1}{1+x}\left|\cos \left(\frac{\pi}{\ln 2} \ln x\right)\right| d x+\frac{1}{a} \int_{a}^{2 a} \frac{1}{1+x}\left|\sin \left(\frac{\pi}{\ln 2} \ln x\right)\right| d x \\
& =\frac{\pi}{\ln 2} \frac{1}{a} \int_{a}^{2 a} \frac{1}{1+x}\left|\sin \left(\frac{\pi}{\ln 2} \ln x+\frac{\pi}{2}\right)\right| d x+\frac{1}{a} \int_{a}^{2 a}|g(x)| d x \\
& =\frac{\pi}{\ln 2} \frac{1}{a} \int_{\sqrt{2} a}^{2 \sqrt{2} a} \frac{1}{\sqrt{2}+t}\left|\sin \left(\frac{\pi}{\ln 2} \ln t\right)\right| d t+\frac{1}{a} \int_{a}^{2 a}|g(x)| d x \quad(t:=\sqrt{2} x) \\
& \leq\left(\frac{\pi}{\ln 2}+1\right) \frac{1}{a} \int_{a /(2 \sqrt{2})}^{2 \sqrt{2} a}|g(x)| d x
\end{aligned}
$$

így a (3.4) feltétel fennáll a $C=\pi / \ln 2+1, \lambda=2 \sqrt{2}$ és tetszőleges $A$ konstans választásával, azaz $g \in \operatorname{MVBVF}\left(\mathbb{R}_{+}\right)$.

Világos, hogy $G(x, y)$ folytonos, $G(x, y) \rightarrow 0$, ha $x+y \rightarrow \infty, x y G(x, y) \in L_{\text {loc }}^{1}\left(\overline{\mathbb{R}}_{+}^{2}\right)$, továbbá

$$
G_{x}(x, y)=g^{\prime}(x) g(y), \quad G_{y}(x, y)=g(x) g^{\prime}(y), \quad G_{x y}(x, y)=g^{\prime}(x) g^{\prime}(y)
$$


$\operatorname{azaz} G(x, y) \in \mathrm{AC}_{\text {loc }}\left(\mathbb{R}_{+}^{2}\right) . G(x, y) \notin \operatorname{NBVF}\left(\mathbb{R}_{+}^{2}\right)$, mivel

$$
\int_{2^{k}}^{2^{k+1}}\left|G_{x}(x, y)\right| d x>0=\left|G\left(2^{k}, y\right)\right|+\left|G\left(2^{k+1}, y\right)\right|, \quad y \neq 2^{k}, k \in \mathbb{Z},
$$

azaz (4.4) nem teljesülhet (hasonlóan, a (4.5) és (4.6) feltételek sem teljesülhetnek). Ezzel szemben, bármely $a_{1}, y>0$ esetén

$$
\begin{aligned}
\int_{a_{1}}^{2 a_{1}}\left|G_{x}(x, y)\right| d x & =|g(y)| \int_{a_{1}}^{2 a_{1}}\left|g^{\prime}(x)\right| d x \leq|g(y)|\left(\frac{\pi}{\ln 2}+1\right) \frac{1}{a_{1}} \int_{a_{1} /(2 \sqrt{2})}^{2 \sqrt{2} a_{1}}|g(x)| d x \\
& =\left(\frac{\pi}{\ln 2}+1\right) \frac{1}{a_{1}} \int_{a_{1} /(2 \sqrt{2})}^{2 \sqrt{2} a_{1}}|G(x, y)| d x
\end{aligned}
$$

hasonlóan,

$$
\int_{a_{2}}^{2 a_{2}}\left|G_{y}(x, y)\right| d y \leq\left(\frac{\pi}{\ln 2}+1\right) \frac{1}{a_{2}} \int_{a_{2} /(2 \sqrt{2})}^{2 \sqrt{2} a_{2}}|G(x, y)| d y, \quad x, a_{2}>0 .
$$

Valamint tetszőleges $a_{1}, a_{2}>0$-ra

$$
\begin{aligned}
\int_{a_{1}}^{2 a_{1}} \int_{a_{2}}^{2 a_{2}}\left|G_{x y}(x, y)\right| d x d y & =\int_{a_{1}}^{2 a_{1}}\left|g^{\prime}(x)\right| d x \cdot \int_{a_{2}}^{2 a_{2}}\left|g^{\prime}(y)\right| d y \\
& \leq\left(\frac{\pi}{\ln 2}+1\right) \frac{1}{a_{1}} \int_{a_{1} /(2 \sqrt{2})}^{2 \sqrt{2} a_{1}}|g(x)| d x \cdot\left(\frac{\pi}{\ln 2}+1\right) \frac{1}{a_{2}} \int_{a_{2} /(2 \sqrt{2})}^{2 \sqrt{2} a_{2}}|g(y)| d y \\
& =\left(\frac{\pi}{\ln 2}+1\right)^{2} \frac{1}{a_{1} a_{2}} \int_{a_{1} /(2 \sqrt{2})}^{2 \sqrt{2} a_{1}} \int_{a_{2} /(2 \sqrt{2})}^{2 \sqrt{2} a_{2}}|G(x, y)| d x d y .
\end{aligned}
$$

Tehát a (4.7)-(4.9) feltételek teljesülnek a $C=\left(\frac{\pi}{\ln 2}+1\right)^{2}$ és $\lambda=2 \sqrt{2}$ konstansokkal, azaz $G \in \operatorname{MVBVF}\left(\mathbb{R}_{+}^{2}\right)$. Ezzel igazoltuk, hogy $G \in \operatorname{MVBVF}\left(\mathbb{R}_{+}^{2}\right) \backslash \operatorname{NBVF}\left(\mathbb{R}_{+}^{2}\right)$.

A 4.2.2. Tétel bizonyítása. Legyen $f \in \operatorname{MVBVF}\left(\mathbb{R}_{+}^{2}\right)$ a $C$, $\lambda$ konstansokkal, valamint tegyük fel, hogy (4.3) fennáll.

(i) rész: Tegyük fel, hogy (4.10) teljesül. Legyen $\varepsilon>0$ tetszőleges, rögzített. Ekkor (4.10) szerint létezik $x_{1}>0$ küszöbszám, melyre (4.14) fennáll. Továbbá, a 4.3.2.Lemma szerint létezik olyan $x_{2}>0$, melyre

$$
a_{1} y \int_{a_{1}}^{\infty}\left|f_{x}(x, y)\right| d x \leq \varepsilon, \quad \text { ha } \quad a_{1}+y>x_{2}, \quad a_{1}, y>0,
$$




$$
\begin{gathered}
x a_{2} \int_{a_{2}}^{\infty}\left|f_{y}(x, y)\right| d y \leq \varepsilon, \quad \text { ha } \quad x+a_{2}>x_{2}, \quad x, a_{2}>0, \\
a_{1} a_{2} \int_{a_{1}}^{\infty} \int_{a_{2}}^{\infty}\left|f_{x y}(x, y)\right| d x d y \leq \varepsilon, \quad \text { ha } a_{1}+a_{2}>x_{2}, \quad a_{1}, a_{2}>0 .
\end{gathered}
$$

Ezután rögzítsük az $x_{0}$ küszöbszámot a következőképpen: $x_{0}:=\max \left\{x_{1}, x_{2}\right\}$.

A következőkben az

$$
I_{f}\left(a_{1}, b_{1} ; a_{2}, b_{2} ; u, v\right)=\int_{a_{1}}^{b_{1}} \int_{a_{2}}^{b_{2}} f(x, y) \sin u x \sin v y d x d y
$$

kettős integrálok abszolút értékét fogjuk becsülni, ahol $a_{1}+a_{2}>x_{0}, b_{1}>a_{1} \geq 0, b_{2}>$ $a_{2} \geq 0$ és $(u, v) \in \mathbb{R}_{+}^{2}$ tetszőleges. Négy alapesetet különböztetünk meg, az $a_{1}, b_{1}$ és az $1 / u$ ill. az $a_{2}, b_{2}$ és az $1 / v$ viszonya alapján. Minden alapesetben és későbbi esetben feltételezzük, hogy $a_{1}+a_{2}>x_{0}$ és $b_{1}>a_{1} \geq 0, b_{2}>a_{2} \geq 0$.

(a) eset: $a_{1}<b_{1} \leq 1 / u$ és $a_{2}<b_{2} \leq 1 / \nu$. Figyelembe véve, hogy

$$
0 \leq \sin u x \leq u x \text {, ha } 0<x \leq 1 / u \text { és } 0 \leq \sin v y \leq v y \text {, ha } 0<y \leq 1 / v \text {, }
$$

valamint (4.14)-et alkalmazva kapjuk, hogy

$$
\begin{aligned}
\left|I_{f}\left(a_{1}, b_{1} ; a_{2}, b_{2} ; u, v\right)\right| & \leq \int_{a_{1}}^{b_{1}} \int_{a_{2}}^{b_{2}}|f(x, y)| u x v y d x d y \leq \frac{1}{b_{1} b_{2}} \int_{a_{1}}^{b_{1}} \int_{a_{2}}^{b_{2}} x y|f(x, y)| d x d y \\
& \leq \frac{1}{b_{1} b_{2}} \int_{a_{1}}^{b_{1}} \int_{a_{2}}^{b_{2}} \varepsilon d x d y \leq \varepsilon .
\end{aligned}
$$

(b) eset: $1 / u \leq a_{1}<b_{1}$ és $a_{2}<b_{2} \leq 1 / \nu$. Először Fubini tételét, majd a $0 \leq \sin v y \leq$ $v y(0<y \leq 1 / v)$ egyenlőtlenséget felhasználva, egy parciális integrálást végrehajtva, végül a (4.14) és (4.16) egyenlőtlenségeket alkalmazva adódik, hogy

$$
\begin{aligned}
\left|I_{f}\left(a_{1}, b_{1} ; a_{2}, b_{2} ; u, v\right)\right| & =\left|\int_{a_{2}}^{b_{2}} \sin v y \cdot\left(\int_{a_{1}}^{b_{1}} f(x, y) \sin u x d x\right) d y\right| \\
& \leq \int_{a_{2}}^{b_{2}} v y\left|\int_{a_{1}}^{b_{1}} f(x, y) \sin u x d x\right| d y \\
& \leq \frac{1}{1 / v} \int_{a_{2}}^{b_{2}} y\left|\left[-f(x, y) \frac{\cos u x}{u}\right]_{a_{1}}^{b_{1}}+\int_{a_{1}}^{b_{1}} f_{x}(x, y) \frac{\cos u x}{u} d x\right| d y \\
& \leq \frac{1}{1 / v} \int_{a_{2}}^{b_{2}}\left(a_{1} y\left|f\left(a_{1}, y\right)\right|+b_{1} y\left|f\left(b_{1}, y\right)\right|+a_{1} y \int_{a_{1}}^{\infty}\left|f_{x}(x, y)\right| d x\right) d y
\end{aligned}
$$




$$
\leq \frac{1}{b_{2}} \int_{a_{2}}^{b_{2}} 3 \varepsilon d y \leq 3 \varepsilon .
$$

(c) eset: $a_{1}<b_{1} \leq 1 / u$ és $1 / v \leq a_{2}<b_{2}$. Ez a (b) eset szimmetrikus párja, analóg módon igazolható, hogy ekkor is

$$
\left|I_{f}\left(a_{1}, b_{1} ; a_{2}, b_{2} ; u, v\right)\right| \leq 3 \varepsilon .
$$

(d) eset: $1 / u \leq a_{1}<b_{1}$ és $1 / v \leq a_{2}<b_{2}$. Ismét a Fubini-tételt alkalmazzuk, kétszer parciálisan integrálunk (először $x$ szerint, majd $y$ szerint), végül a (4.14) és a (4.16)(4.18) egyenlőtlenségeket alkalmazzuk:

$$
\begin{aligned}
\left|I_{f}\left(a_{1}, b_{1} ; a_{2}, b_{2} ; u, v\right)\right|= & \left|\int_{a_{2}}^{b_{2}} \sin v y \cdot\left(\left[-f(x, y) \frac{\cos u x}{u}\right]_{a_{1}}^{b_{1}}+\int_{a_{1}}^{b_{1}} f_{x}(x, y) \frac{\cos u x}{u} d x\right) d y\right| \\
= & \mid\left[\frac{\cos v y}{v}\left(\left[f(x, y) \frac{\cos u x}{u}\right]_{a_{1}}^{b_{1}}-\int_{a_{1}}^{b_{1}} f_{x}(x, y) \frac{\cos u x}{u} d x\right)\right]_{a_{2}}^{b_{2}} \\
& -\int_{a_{2}}^{b_{2}} \frac{\cos v y}{v} \cdot \frac{\partial}{\partial y}\left(\left[f(x, y) \frac{\cos u x}{u}\right]_{a_{1}}^{b_{1}}-\int_{a_{1}}^{b_{1}} f_{x}(x, y) \frac{\cos u x}{u} d x\right) d y \mid \\
= & \mid\left[\frac{\cos v y}{v}\left[f(x, y) \frac{\cos u x}{u}\right]_{a_{1}}^{b_{1}}\right]_{a_{2}}^{b_{2}}-\left[\frac{\cos v y}{v} \int_{a_{1}}^{b_{1}} f_{x}(x, y) \frac{\cos u x}{u} d x\right]_{a_{2}}^{b_{2}} \\
& -\int_{a_{2}}^{b_{2}} \frac{\cos v y}{v}\left[f_{y}(x, y) \frac{\cos u x}{u}\right]_{a_{1}}^{b_{1}} d y \\
& +\int_{a_{2}}^{b_{2}} \frac{\cos v y}{v}\left(\int_{a_{1}}^{b_{1}} f_{x y}(x, y) \frac{\cos u x}{u} d x\right) d y \mid \\
\leq & b_{1} b_{2}\left|f\left(b_{1}, b_{2}\right)\right|+a_{1} b_{2}\left|f\left(a_{1}, b_{2}\right)\right|+b_{1} a_{2}\left|f\left(b_{1}, a_{2}\right)\right|+a_{1} a_{2}\left|f\left(a_{1}, a_{2}\right)\right| \\
+ & a_{1} b_{2} \int_{a_{1}}^{\infty}\left|f_{x}\left(x, b_{2}\right)\right| d x+a_{1} a_{2} \int_{a_{1}}^{\infty}\left|f_{x}\left(x, a_{2}\right)\right| d x \\
+ & b_{1} a_{2} \int_{a_{2}}^{\infty}\left|f_{y}\left(b_{1}, y\right)\right| d y+\int_{a_{1}}^{\infty}\left|\int_{a_{2}}^{\infty}\right| f_{y}\left(a_{1}, y\right) \mid d y \\
\leq & \\
a_{2} & \\
&
\end{aligned}
$$

Az alapesetekben kapott becslések alapján belátjuk, hogy tetszőleges $(u, v)$ esetén

$$
\left|I_{f}\left(a_{1}, b_{1} ; a_{2}, b_{2} ; u, v\right)\right| \leq 16 \varepsilon, \quad a_{1}+a_{2}>x_{0}\left(b_{1}>a_{1} \geq 0, b_{2}>a_{2} \geq 0\right) .
$$


Legyen $(u, v)$ tetszőleges, rögzített számpár. A 2.2.2. Tétel bizonyításához hasonlóan itt is kilenc esetet kell tárgyalnunk.

1. eset: $a_{1}<b_{1} \leq 1 / u$ és $a_{2}<b_{2} \leq 1 / v$. Ez megegyezik (a) alapesettel, ekkor $\left|I_{f}\left(a_{1}, b_{1} ; a_{2}, b_{2} ; u, v\right)\right| \leq \varepsilon$.

2. eset: $1 / u \leq a_{1}<b_{1}$ és $a_{2}<b_{2} \leq 1 / v$. Ezt az esetet vizsgáltuk (b)-ben. Tehát $\left|I_{f}\left(a_{1}, b_{1} ; a_{2}, b_{2} ; u, v\right)\right| \leq 3 \varepsilon$.

3. eset: $a_{1}<1 / u<b_{1}$ és $a_{2}<b_{2} \leq 1 / v$. Ekkor az (a) és (b) alapesetekbeli becsléseket felhasználva kapjuk, hogy

$$
\left|I_{f}\left(a_{1}, b_{1} ; a_{2}, b_{2} ; u, v\right)\right| \leq\left|I_{f}\left(a_{1}, 1 / u ; a_{2}, b_{2} ; u, v\right)\right|+\left|I_{f}\left(1 / u, b_{1} ; a_{2}, b_{2} ; u, v\right)\right| \leq 4 \varepsilon .
$$

4. eset: $a_{1}<b_{1} \leq 1 / u$ és $1 / v \leq a_{2}<b_{2}$. Ezt az esetet tárgyaltuk (c)-ben. Ekkor $\left|I_{f}\left(a_{1}, b_{1} ; a_{2}, b_{2} ; u, v\right)\right| \leq 3 \varepsilon$.

5. eset: $1 / u \leq a_{1}<b_{1}$ és $1 / v \leq a_{2}<b_{2}$. Ez megegyezik (d) alapesettel, tehát $\left|I_{f}\left(a_{1}, b_{1} ; a_{2}, b_{2} ; u, v\right)\right| \leq 9 \varepsilon$.

6. eset: $a_{1}<1 / u<b_{1}$ és $1 / v \leq a_{2} \leq b_{2}$. A (c) és (d) alapesetekbeli becsléseket felhasználva kapjuk, hogy

$$
\left|I_{f}\left(a_{1}, b_{1} ; a_{2}, b_{2} ; u, v\right)\right| \leq\left|I_{f}\left(a_{1}, 1 / u ; a_{2}, b_{2} ; u, v\right)\right|+\left|I_{f}\left(1 / u, b_{1} ; a_{2}, b_{2} ; u, v\right)\right| \leq 12 \varepsilon .
$$

7. eset: $a_{1}<b_{1} \leq 1 / u$ és $a_{2}<1 / v<b_{2}$. Az (a) és (c) alapesetek figyelembe vételével

$$
\left|I_{f}\left(a_{1}, b_{1} ; a_{2}, b_{2} ; u, v\right)\right| \leq\left|I_{f}\left(a_{1}, b_{1} ; a_{2}, 1 / v ; u, v\right)\right|+\left|I_{f}\left(a_{1}, b_{1} ; 1 / v, b_{2} ; u, v\right)\right| \leq 4 \varepsilon .
$$

8. eset: $1 / u \leq a_{1}<b_{1}$ és $a_{2}<1 / v<b_{2}$. Az (b) és (d) alapeseteket felhasználva adódik, hogy

$$
\left|I_{f}\left(a_{1}, b_{1} ; a_{2}, b_{2} ; u, v\right)\right| \leq\left|I_{f}\left(a_{1}, b_{1} ; a_{2}, 1 / v ; u, v\right)\right|+\left|I_{f}\left(a_{1}, b_{1} ; 1 / v, b_{2} ; u, v\right)\right| \leq 12 \varepsilon .
$$

9. eset: $a_{1}<1 / u<b_{1}$ és $a_{2}<1 / v<b_{2}$. Az (a)-(d) alapeseteket összegezve kapjuk, hogy

$$
\begin{aligned}
\left|I_{f}\left(a_{1}, b_{1} ; a_{2}, b_{2} ; u, v\right)\right| \leq & \left|I_{f}\left(a_{1}, 1 / u ; a_{2}, 1 / v ; u, v\right)\right|+\left|I_{f}\left(1 / u, b_{1} ; a_{1}, 1 / v ; u, v\right)\right| \\
& +\left|I_{f}\left(a_{1}, 1 / u ; 1 / v, b_{2} ; u, v\right)\right|+\left|I_{f}\left(1 / u, b_{1} ; 1 / v, b_{2} ; u, v\right)\right| \leq 16 \varepsilon .
\end{aligned}
$$

Ezzel beláttuk (4.19)-et, ami azt jelenti, hogy (4.1) reguláris konvergenciája egyenletes $(u, v)$-ben, azaz az (i) rész bizonyítást nyert.

(ii) rész: Tegyük fel, hogy $f: \mathbb{R}_{+}^{2} \rightarrow \overline{\mathbb{R}}_{+}$és (4.1) reguláris konvergenciája egyenletes $(u, v)$-ben. Legyen $a_{1}, a_{2}>0$ tetszőleges,

$$
u\left(a_{1}\right):=\frac{\pi}{2 \lambda a_{1}} \quad \text { és } \quad v\left(a_{2}\right):=\frac{\pi}{2 \lambda a_{2}} .
$$


Ekkor

$$
\sin \left(u\left(a_{1}\right) x\right) \geq \sin \frac{\pi}{2 \lambda^{2}}, \quad \text { ha } \quad a_{1} / \lambda \leq x \leq \lambda a_{1}
$$

és

$$
\sin \left(v\left(a_{2}\right) y\right) \geq \sin \frac{\pi}{2 \lambda^{2}}, \quad \text { ha } \quad a_{2} / \lambda \leq y \leq \lambda a_{2} .
$$

Kihasználva a 4.3.3. Lemmabeli (4.15)-öt, valamint $f$ nemnegatív voltát, adódik

$$
\begin{aligned}
\int_{a_{1} / \lambda}^{\lambda a_{1}} \int_{a_{2} / \lambda}^{\lambda a_{2}} f(x, y) \sin \left(u\left(a_{1}\right) x\right) \sin \left(v\left(a_{2}\right) y\right) d x d y & \geq\left(\sin \frac{\pi}{2 \lambda^{2}}\right)^{2} \int_{a_{1} / \lambda}^{\lambda a_{1}} \int_{a_{2} / \lambda}^{\lambda a_{2}} f(x, y) d x d y \\
& \geq\left(\sin \frac{\pi}{2 \lambda^{2}}\right)^{2} \frac{1}{(3 C+1)} a_{1} a_{2} f\left(a_{1}, a_{2}\right),
\end{aligned}
$$

ahol a bal oldal 0-hoz tart, ha $a_{1}+a_{2} \rightarrow \infty$, mivel (4.1) reguláris konvergenciája egyenletes $(u, v)$-ben. Így a jobb oldal is 0 -hoz tart, azaz

$$
a_{1} a_{2} f\left(a_{1}, a_{2}\right) \rightarrow 0, \quad \text { ha } \quad a_{1}+a_{2} \rightarrow \infty,
$$

ezzel (4.10)-et igazoltuk. 


\section{Irodalomjegyzék}

[1] T. W. Chaundy és A. E. Jolliffe, The uniform convergence of a certain class of trigonometric series, Proc. London Math. Soc., 15 (1916), 214-216.

[2] M. DyaChenko, E. Liflyand és S. TikHonov, Uniform convergence and integrability of Fourier integrals, J. Math. Anal. Appl., 372 (2010), 328-338.

[3] M. Dyachenko és S. Tikhonov, Integrability and continuity of functions represented by trigonometric series: coefficients criteria, Studia Math., 193 (2009), 285-306.

[4] P. KóRUS, Remarks on the uniform and $L^{1}$-convergence of trigonometric series, Acta Math. Hungar., 128 (4) (2010), 369-380.

[5] P. KóRUS, On the uniform convergence of special sine integrals, Acta Math. Hungar., 133 (1) (2011), 82-91.

[6] P. KóRUS, On the uniform convergence of double sine series with generalized monotone coefficients, Periodica Math. Hungar., 63 (2) (2011), 205-214.

[7] P. KóRUS és F. Móricz, On the uniform convergence of double sine series, Studia Math., 193 (2009), 79-97.

[8] P. KÓRUS és F. MÓRICZ, Generalizations to monotonicity for uniform convergence of double sine integrals over $\overline{\mathbb{R}}_{+}^{2}$, Studia Math., 201 (2010), 287-304.

[9] F. MÓRICZ, Some remarks on the notion of regular convergence of multiple series, Acta Math. Acad. Sci. Hungar., 41 (1983), 161-168.

[10] F. Móricz, On the uniform convergence of sine integrals, J. Math. Anal. Appl., 354 (2009), 213-219.

[11] F. MóRICZ, On the uniform convergence of double sine integrals over $\overline{\mathbb{R}}_{+}^{2}$, Analysis (München), 31 (2011), 191-204. 
[12] R. E. A. C. Paley, On Fourier series with positive coefficients, J. London Math. Soc., 7 (1932), 205-208.

[13] S. Tikhonov, On $L_{1}$-convergence of Fourier series, J. Math. Anal. Appl., 347 (2008), 416-427.

[14] I. E. ŽAK és A. A. ŠNEIDER, Conditions for uniform convergence of double sine series (orosz), Izv. Vyš̌. Učebn. Zaved. Mat., 4 (1966), 44-52.

[15] D. S. Yu és S. P. ZHOU, A generalization of monotonicity condition and applications, Acta Math. Hungar., 115 (2007), 247-267.

[16] S. P. ZHоU, P. ZHoU és D. S. Yu, Ultimate generalization to monotonicity for uniform convergence of trigonometric series, online: http://arxiv.org/abs/math/0611805v1.

[17] A. Zygmund, Trigonometric Series, Vol. I, Cambridge University Press, 1959.

\section{Köszönetnyilvánítás}

Ezúton szeretném megköszönni témavezetőmnek, Dr. Móricz Ferencnek az elmúlt években adott tanácsait, útmutatásait. Publikációs téren nyújtott segítsége nagy mértékben segítette munkámat, mely nélkül nem születhettek volna meg publikációs eredményeim és ezen dolgozat. Emellett köszönöm az SZTE Matematika- és Számítástudományok Doktori Iskolájának támogatását. 


\section{Összefoglalás}

A disszertációban a szinuszsorok, kettős szinuszsorok, szinuszintegrálok és kettős szinuszintegrálok egyenletes konvergenciáját vizsgáljuk. A négy témakört a négy fejezetben külön-külön tárgyaljuk, azonban a kettős sorokra ill. integrálokra kapott eredmények esetében kihasználjuk az egyszeres sorokra ill.integrálokra bebizonyított állítások érvényességét. Az kétváltozós eredmények nem triviális kiterjesztései az egy változóban kapott eredményeknek, bár a bizonyítások között analógia felfedezhető, két változó esetén a konvergencia fogalma összetettebb, mint a jól ismert egyváltozós konvergencia fogalom, valamint a bevezetésre kerülő kétváltozós sorozat ill. függvényosztályok definiálása is több meggondolást igényel az egyváltozós esethez képest.

A dolgozat a szerző [4], [5], [6], [7], [8] cikkeiben elért eredményein alapul.

\section{Szinuszsorok}

Ebben a részben a

$$
\sum_{k=1}^{\infty} c_{k} \sin k x
$$

szinuszsorok egyenletes konvergenciájára bebizonyított állításokat foglaljuk össze.

$\mathrm{A}\left\{c_{k}\right\}_{k=1}^{\infty} \subset \mathbb{C}$ együtthatókról azt feltételezzük, hogy általánosított monoton sorozat elemei. Kutatásunk célja az MVBVS sorozatosztály megfelelő kibővítése volt, ahol MVBVS osztályt S. P. Zhou, P. Zhou és D. S. Yu [16]-ban definiálta: $\left\{c_{k}\right\} \in$ MVBVS (Mean Value Bounded Variation Sequences), ha léteznek $C, \lambda \geq 2$ konstansok, melyek teljesítik a

$$
\sum_{k=n}^{2 n-1}\left|\Delta c_{k}\right| \leq \frac{C}{n} \sum_{k=[n / \lambda]}^{[\lambda n]}\left|c_{k}\right|
$$

feltételt. MVBVS tartalmazza a nemnegatív, monoton nemnövő sorozatokat és az addig használt általánosított monoton sorozatosztályokat is.

Definíció. A $\left\{c_{k}\right\} \subset \mathbb{C}$ sorozatot Supremum Bounded Variation Sequence-nek nevezzük, jelben $\left\{c_{k}\right\} \in$ SBVS, ha léteznek olyan $C$ és $\lambda \geq 1$ konstans számok, melyek csak $\left\{c_{k}\right\}$-tól 
függnek, és

$$
\sum_{k=n}^{2 n-1}\left|\Delta c_{k}\right| \leq \frac{C}{n} \sup _{m \geq[n / \lambda]} \sum_{k=m}^{2 m}\left|c_{k}\right|
$$

fennáll minden $n \geq 1$ esetén.

Definíció. A $\left\{c_{k}\right\} \subset \mathbb{C}$ sorozatot Supremum Bounded Variation Sequence of 2nd typenak nevezzük, jelben $\left\{c_{k}\right\} \in \mathrm{SBVS}_{2}$, ha létezik olyan $C$ konstans és végtelenbe tartó $\{b(k)\}_{k=1}^{\infty} \subset \overline{\mathbb{R}}_{+}=[0, \infty)$ sorozat, melyek csak $\left\{c_{k}\right\}$-tól függnek, és amelyekre

$$
\sum_{k=n}^{2 n-1}\left|\Delta c_{k}\right| \leq \frac{C}{n} \sup _{m \geq b(n)} \sum_{k=m}^{2 m}\left|c_{k}\right| .
$$

1.2.1. Tétel. SBVS $_{2} \supsetneqq \mathrm{SBVS} \supsetneqq \mathrm{MVBVS}$.

1.2.2. Tétel. Legyen $\left\{c_{k}\right\} \subset \mathbb{C}$ sorozat $\mathrm{SBVS}_{2}$-beli.

(i) $\mathrm{Ha}$

$$
k c_{k} \rightarrow 0, \quad h a \quad k \rightarrow \infty,
$$

akkor (1.1) egyenletesen konvergens $x$-ben.

(ii) Megfordítva, ha $\left\{c_{k}\right\} \subset \overline{\mathbb{R}}_{+}$és (1.1) konvergenciája egyenletes $x$-ben, akkor (1.2) fennáll.

1.2.3. Következmény. Ha $a\left\{c_{k}\right\} \subset \overline{\mathbb{R}}_{+}$sorozat $\mathrm{SBVS}_{2}$-beli, akkor (1.2) szükséges és elegendö feltétel az (1.1) sor x-ben vett egyenletes konvergenciájához.

1.2.4. Állítás. Bármely olyan $\mathrm{SBVS}_{2}$-beli sorozatra, mely nem SBVS-beli, (1.2) fennáll. Azaz az ilyen együtthatójú szinuszsorok egyenletesen konvergensek.

Ezen részben vizsgáltuk még a

$$
\sum_{k=1}^{\infty} k^{r} c_{k} \sin k x
$$

alakú szinuszsort is, mely pozitív páros $r$ esetén (1.1) $r$-szeres formális deriváltja, negatív páros $r$ esetén (1.1) $r$-szeres formális integrálja.

1.4.1. Tétel. $H a\left\{c_{k}\right\}$ sorozat MVBVS-beli, akkor $\left\{d_{k}=k^{r} c_{k}\right\}$ szintén MVBVS-beli tetszöleges rögzített $r$ egész szám esetén.

1.4.2. Következmény. Legyen $\left\{c_{k}\right\} \in \mathrm{MVBVS}$ és $r$ páros szám.

(i) $\mathrm{Ha}^{r+1} c_{k} \rightarrow 0$, akkor (1.9) egyenletesen konvergens $x$-ben.

(ii) Megforditva, ha $\left\{c_{k}\right\} \subset \overline{\mathbb{R}}_{+}$és (1.9) egyenletesen konvergens $x$-ben, akkor $k^{r+1} c_{k} \rightarrow 0$. 
1.4.3. Tétel. $H a\left\{c_{k}\right\}$ sorozat SBVS-beli, akkor $\left\{d_{k}=k^{r} c_{k}\right\}$ szintén SBVS-beli tetszőleges rögzített r pozitív egész szám esetén.

1.4.4. Következmény. $H a\left\{c_{k}\right\} \in$ SBVS és $r$ pozitív páros szám, akkor az 1.4.2. Következmény (i) és (ii) állításai fennállnak.

\section{Kettős szinuszsorok}

Legyen $\left\{c_{j k}\right\}_{j, k=1}^{\infty} \subset \mathbb{C}$, és tekintsük a

$$
\sum_{j=1}^{\infty} \sum_{k=1}^{\infty} c_{j k} \sin j x \sin k y
$$

kettős szinuszsort. Ezen kettős sor egyenletes, reguláris konvergenciája adunk elegendő, illetve szükséges feltételeket. Az együtthatókról ekkor is feltételezzük, hogy általánosított monoton sorozat elemei.

Definíció. A $\left\{c_{j k}\right\} \subset \mathbb{C}$ kettős sorozatot MVBVDS-belinek (Mean Value Bounded Variation Double Sequences) nevezzük, ha léteznek $C$ és $\lambda \geq 2$ konstans számok, melyek csak $\left\{c_{j k}\right\}$-tól függnek, és amelyekre

$$
\begin{aligned}
\sum_{j=m}^{2 m-1}\left|\Delta_{10} c_{j n}\right| & \leq \frac{C}{m} \sum_{j=[m / \lambda]}^{[\lambda m]}\left|c_{j n}\right|, \quad m \geq \lambda, n \geq 1, \\
\sum_{k=n}^{2 n-1}\left|\Delta_{01} c_{m k}\right| & \leq \frac{C}{n} \sum_{k=[n / \lambda]}^{[\lambda n]}\left|c_{m k}\right|, \quad m \geq 1, n \geq \lambda, \\
\sum_{j=m}^{2 m-1} \sum_{k=n}^{2 n-1}\left|\Delta_{11} c_{j k}\right| & \leq \frac{C}{m n} \sum_{j=[m / \lambda]}^{[\lambda m]} \sum_{k=[n / \lambda]}^{[\lambda n]}\left|c_{j k}\right|, \quad m, n \geq \lambda .
\end{aligned}
$$

2.2.2. Tétel. Legyen $\left\{c_{j k}\right\} \subset \mathbb{C}$ kettős sorozat MVBVDS-beli.

(i) $\mathrm{Ha}$

$$
j k c_{j k} \rightarrow 0, \quad \text { ha } j+k \rightarrow \infty
$$

akkor (2.1) reguláris konvergenciája egyenletes $(x, y)$-ban.

(ii) Megfordítva, ha $\left\{c_{j k}\right\} \subset \overline{\mathbb{R}}_{+}$és (2.1) reguláris konvergenciája egyenletes $(x, y)$-ban, akkor (2.2) fennáll.

Ezen kívül megmutattuk, hogy az MVBVDS osztály tartalmazza NBVDS-t, amely osztály pedig tartalmazza a nemnegatív, monoton nemnövő kettős sorozatokat. Később MVBVDS-t tovább általánosítottuk, mely által megkaptuk a 2.2.2. Tétel kiterjesztését. 
Definíció. $\left\{c_{j k}\right\}_{j, k=1}^{\infty} \subset \mathbb{C}$ kettős sorozat SBVDS $_{1}$-beli (Supremum Bounded Variation Double Sequences of 1st type), ha léteznek olyan $C$ és $\lambda \geq 2$ konstansok illetve $\left\{b_{1}(l)\right\}_{l=1}^{\infty}$, $\left\{b_{2}(l)\right\}_{l=1}^{\infty},\left\{b_{3}(l)\right\}_{l=1}^{\infty}$ végtelenbe tartó sorozatok, melyek csak $\left\{c_{j k}\right\}$-tól függnek, és amelyekre

$$
\begin{aligned}
\sum_{j=m}^{2 m-1}\left|\Delta_{10} c_{j n}\right| & \leq \frac{C}{m} \max _{b_{1}(m) \leq M \leq \lambda b_{1}(m)} \sum_{j=M}^{2 M}\left|c_{j n}\right|, \quad m \geq \lambda, n \geq 1, \\
\sum_{k=n}^{2 n-1}\left|\Delta_{01} c_{m k}\right| & \leq \frac{C}{n} \max _{b_{2}(n) \leq N \leq \lambda b_{2}(n)} \sum_{k=N}^{2 N}\left|c_{m k}\right|, \quad m \geq 1, n \geq \lambda, \\
\sum_{j=m}^{2 m-1} \sum_{k=n}^{2 n-1}\left|\Delta_{11} c_{j k}\right| & \leq \frac{C}{m n} \sup _{M+N \geq b_{3}(m+n)} \sum_{j=M}^{2 M} \sum_{k=N}^{2 N}\left|c_{j k}\right|, \quad m, n \geq \lambda .
\end{aligned}
$$

Definíció. $\left\{c_{j k}\right\}_{j, k=1}^{\infty} \subset \mathbb{C}$ kettős sorozat SBVDS $_{2}$-beli (Supremum Bounded Variation Double Sequences of 2nd type), ha léteznek olyan $C, \lambda \geq 2$ konstansok és $\{b(l)\}_{l=1}^{\infty}$ végtelenbe tartó sorozat, melyek csak $\left\{c_{j k}\right\}$-tól függnek, és amelyekre

$$
\begin{aligned}
\sum_{j=m}^{2 m-1}\left|\Delta_{10} c_{j n}\right| & \leq \frac{C}{m} \sup _{M \geq b(m)} \sum_{j=M}^{2 M}\left|c_{j n}\right|, \quad m \geq \lambda, n \geq 1, \\
\sum_{k=n}^{2 n-1}\left|\Delta_{01} c_{m k}\right| & \leq \frac{C}{n} \sup _{N \geq b(n)} \sum_{k=N}^{2 N}\left|c_{m k}\right|, \quad m \geq 1, n \geq \lambda, \\
\sum_{j=m}^{2 m-1} \sum_{k=n}^{2 n-1}\left|\Delta_{11} c_{j k}\right| & \leq \frac{C}{m n} \sup _{M+N \geq b(m+n)} \sum_{j=M}^{2 M} \sum_{k=N}^{2 N}\left|c_{j k}\right|, \quad m, n \geq \lambda .
\end{aligned}
$$

2.5.1. Tétel. $\operatorname{SBVDS}_{2} \supsetneqq \operatorname{SBVDS}_{1} \supsetneqq \mathrm{MVBVDS}_{\text {. }}$

2.5.2. Tétel. (i) Ha a $\left\{c_{j k}\right\} \subset \mathbb{C}$ sorozat $\mathrm{SBVDS}_{2}$-beli, valamint (2.2) teljesül, akkor (2.1) reguláris konvergenciája egyenletes $(x, y)$-ban.

(ii) Megfordítva, ha a $\left\{c_{j k}\right\} \subset \overline{\mathbb{R}}_{+}$sorozat $\mathrm{SVBVDS}_{1}$-beli és (2.1) reguláris konvergenciája egyenletes $(x, y)$-ban, akkor (2.2) fennáll.

\section{Szinuszintegrálok}

Ebben a részben az

$$
\int_{0}^{\infty} f(x) \sin t x d x
$$

szinuszintegrálok $t$-ben vett egyenletes konvergenciáját vizsgáltuk, ahol $f: \mathbb{R}_{+} \rightarrow \mathbb{C}$ Lebesgue-mérhető függvény, $\mathbb{R}_{+}:=(0, \infty), t \in \mathbb{R}$, valamint

$$
x f(x) \in L_{\mathrm{loc}}^{1}\left(\overline{\mathbb{R}}_{+}\right) .
$$


Kibővítettük a [10]-ben definiált - az $\mathbb{R}_{+}$-on értelmezett, nemnegatív, lokálisan abszolút folytonos, monoton nemcsökkenő függvények osztályánál bővebb - $\operatorname{MVBVF}\left(\mathbb{R}_{+}\right)$ osztályt, aminek segítségével általánosítottuk az ottani eredményeket.

Definíció. Az $f(x) \in \mathrm{AC}_{\text {loc }}\left(\mathbb{R}_{+}\right.$) függvényt $\operatorname{SBVF}\left(\mathbb{R}_{+}\right)$-belinek (Supremum Bounded Variation Function-nek) nevezzük, ha léteznek a $C, A>0$ és $\lambda \geq 2$ konstansok, melyek csak $f$-től függnek, és amelyekre

$$
\int_{a}^{2 a}\left|f^{\prime}(x)\right| d x \leq \frac{C}{a} \sup _{b \geq a / \lambda} \int_{b}^{2 b}|f(x)| d x, \quad a>A .
$$

Definíció. Az $f(x) \in \mathrm{AC}_{\text {loc }}\left(\mathbb{R}_{+}\right.$) függvény $\mathrm{SBVF}_{2}\left(\mathbb{R}_{+}\right)$-beli (Supremum Bounded Variation Function of 2nd type), ha léteznek a $C, A>0$ konstansok és a $B(x) \subset \overline{\mathbb{R}}_{+}$végtelenbe tartó függvény, melyek csak $f$-től függnek, és amelyekre

$$
\int_{a}^{2 a}\left|f^{\prime}(x)\right| d x \leq \frac{C}{a} \sup _{b \geq B(a)} \int_{b}^{2 b}|f(x)| d x, \quad a>A .
$$

3.2.1. Tétel. Ha $f(x) \in \operatorname{MVBVF}\left(\mathbb{R}_{+}\right)$, akkor $f(x) \in \operatorname{SBVF}\left(\mathbb{R}_{+}\right)$. A forditott irányú állitás nem igaz, azaz létezik olyan $f(x) \in \operatorname{SBVF}\left(\mathbb{R}_{+}\right)$, mely nem $\operatorname{MVBVF}\left(\mathbb{R}_{+}\right)$-beli. Röviden, $\operatorname{SBVF}\left(\mathbb{R}_{+}\right) \supsetneqq \operatorname{MVBVF}\left(\mathbb{R}_{+}\right)$.

3.2.2. Tétel. $\operatorname{SBVF}_{2}\left(\mathbb{R}_{+}\right) \supsetneqq \operatorname{SBVF}\left(\mathbb{R}_{+}\right)$. Továbbá, ha $f(x) \in \mathrm{SBVF}_{2}\left(\mathbb{R}_{+}\right) \backslash \mathrm{SBVF}\left(\mathbb{R}_{+}\right)$, akkor

$$
x f(x) \rightarrow 0, \quad \text { ha } \quad x \rightarrow \infty .
$$

3.2.3. Tétel. Tegyük fel, hogy $f(x) \in \mathrm{SBVF}_{2}\left(\mathbb{R}_{+}\right)$és (3.2) fennáll.

(i) Ha $f: \mathbb{R}_{+} \rightarrow \mathbb{C}$ és (3.3) teljesül, akkor a (3.1) integrál egyenletesen konvergens $t$-ben.

(ii) Megfordítva, ha $f: \mathbb{R}_{+} \rightarrow \overline{\mathbb{R}}_{+}$és (3.1) konvergenciája egyenletes $t$-ben, akkor (3.3) fennáll.

Végül jellemeztük az

$$
\int_{0}^{\infty} x^{r} f(x) \sin t x d x
$$

szinuszintegrál egyenletes konvergenciáját, mely pozitív páros $r$ esetén (3.1) $r$-szeres formális deriváltja, negatív páros $r$ esetén (3.1) $r$-szeres formális integrálja.

3.4.1. Tétel. Legyen $f(x) \in \operatorname{MVBVF}\left(\mathbb{R}_{+}\right)$. Ekkor tetszöleges rögzített $r$ egész szám esetén $g_{r}(x)=x^{r} f(x)$ szintén MVBVF $\left(\mathbb{R}_{+}\right)$-beli. 
3.4.2. Következmény. Tegyük fel, hogy $f(x) \in \operatorname{MVBVF}\left(\mathbb{R}_{+}\right)$, (3.2) fennáll és $r$ pozitív páros szám.

(i) Ha $f: \mathbb{R}_{+} \rightarrow \mathbb{C}$ és $x^{r+1} f(x) \rightarrow 0$, ha $x \rightarrow \infty$, akkor a (3.10) szinuszintegrál egyenletesen konvergens $t$-ben.

(ii) Megfordítva, ha $f: \mathbb{R}_{+} \rightarrow \overline{\mathbb{R}}_{+}$és a (3.10) integrál konvergenciája egyenletes $t$-ben, akkor $x^{r+1} f(x) \rightarrow 0$, ha $x \rightarrow \infty$.

Az iménti állítások igazak maradnak akkor is, ha r negatív páros szám és $x^{r+1} f(x) \in$ $L_{\text {loc }}^{1}\left(\overline{\mathbb{R}}_{+}\right)$.

3.4.3. Tétel. Tegyük fel, hogy $f(x) \in \mathrm{SBVF}\left(\mathbb{R}_{+}\right)$. Ekkor tetszöleges rögzített r pozitív egész szám esetén $g_{r}(x)=x^{r} f(x) \in \operatorname{SBVF}\left(\mathbb{R}_{+}\right)$.

3.4.4. Következmény. $H a f(x) \in \operatorname{SBVF}\left(\mathbb{R}_{+}\right)$, (3.2) fennáll és $r$ pozitív páros szám, akkor a 3.4.2. Következmény (i) és (ii) állításai fennállnak.

\section{Kettős szinuszintegrálok}

Tekintsük az

$$
\int_{0}^{\infty} \int_{0}^{\infty} f(x, y) \sin u x \sin v y d x d y, \quad(u, v) \in \mathbb{R}^{2}
$$

alakú kettős szinuszintegrálokat, ahol $f(x, y): \mathbb{R}_{+}^{2} \rightarrow \mathbb{C}$ Lebesgue-mérhető függvény. Az $f$ kétváltozós függvényről feltesszük, hogy lokálisan abszolút folytonos és

$$
x y f(x, y) \in L_{\mathrm{loc}}^{1}\left(\overline{\mathbb{R}}_{+}^{2}\right) .
$$

Definíció. $\mathrm{Az} f(x, y) \in \mathrm{AC}_{\text {loc }}\left(\mathbb{R}_{+}^{2}\right)$ függvényt $\operatorname{MVBVF}\left(\mathbb{R}_{+}^{2}\right)$-belinek nevezzük, ha léteznek olyan, csak $f$-től függő, $C$ és $\lambda \geq 2$ konstansok, amelyekre

$$
\begin{gathered}
\int_{a_{1}}^{2 a_{1}}\left|f_{x}(x, y)\right| d x \leq \frac{C}{a_{1}} \int_{a_{1} / \lambda}^{\lambda a_{1}}|f(x, y)| d x, \quad a_{1}, y>0, \\
\int_{a_{2}}^{2 a_{2}}\left|f_{y}(x, y)\right| d y \leq \frac{C}{a_{2}} \int_{a_{2} / \lambda}^{\lambda a_{2}}|f(x, y)| d y, \quad x, a_{2}>0, \\
\int_{a_{1}}^{2 a_{1}} \int_{a_{2}}^{2 a_{2}}\left|f_{x y}(x, y)\right| d x d y \leq \frac{C}{a_{1} a_{2}} \int_{a_{1} / \lambda}^{\lambda a_{1}} \int_{a_{2} / \lambda}^{\lambda a_{2}}|f(x, y)| d x d y, \quad a_{1}, a_{2}>0 .
\end{gathered}
$$


4.2.2. Tétel. Legyen $f \in \operatorname{MVBVF}\left(\mathbb{R}_{+}^{2}\right)$ olyan függvény, amelyre (4.3) fennáll.

(i) $H a f: \mathbb{R}_{+}^{2} \rightarrow \mathbb{C}$ és

$$
x y f(x, y) \rightarrow 0, \quad \text { ha } \quad x+y \rightarrow \infty
$$

akkor a (4.1) integrál reguláris konvergenciája egyenletes $(u, v) \in \mathbb{R}_{+}^{2}$-ben.

(ii) Megfordítva, ha $f: \mathbb{R}_{+}^{2} \rightarrow \overline{\mathbb{R}}_{+}$és a (4.1) reguláris konvergenciája egyenletes $(u, v) \in \mathbb{R}_{+}^{2}$ ben, akkor (4.10) fennáll.

Továbbá megmutattuk, hogy $\operatorname{MVBVF}\left(\mathbb{R}_{+}^{2}\right)$ osztály tartalmazza az $\operatorname{NBVF}\left(\mathbb{R}_{+}^{2}\right)$ osztályt, amely osztály pedig bővebb az $\mathbb{R}_{+}^{2}$-en értelmezett, nemnegatív, lokálisan abszolút folytonos, monoton nemcsökkenő függvények osztályánál.

4.2.4. Következmény. Ha $f: \mathbb{R}_{+}^{2} \rightarrow \overline{\mathbb{R}}_{+}$monoton nemnövö és $f \in \mathrm{AC}_{\text {loc }}\left(\mathbb{R}_{+}^{2}\right)$, akkor (4.10) szükséges és elegendö feltétele annak, hogy (4.1) egyenletesen konvergens legyen $(u, v)$ ben. 


\section{Summary}

Our research deals with the uniform convergence of sine series, double sine series, sine integrals and double sine integrals. The four topics are discussed in four single chapters, however, in case of double series and integrals, we use the known results for single series and integrals. Although there are some analogies between the one and two-variable cases, the two-variable cases are nontrivial extensions of the one-variable ones, since the notion of convergence in two variables are more complicated than the well-known convergence notion in one variable. Moreover, the definitions of general monotone classes of double series and two-variable functions are not as obvious as the ones of single series and one-variable functions.

The dissertation is based on papers [4], [5], [6], [7], [8] of the author.

\section{Sine series}

In this section we summarize our results for the series

$$
\sum_{k=1}^{\infty} c_{k} \sin k x
$$

We suppose that coefficients $\left\{c_{k}\right\}_{k=1}^{\infty} \subset \mathbb{C}$ are from a general monotone class of sequences. The main goal of our research was to expand class MVBVS appropriately where the notion of MVBVS was introduced by S. P. Zhou, P. Zhou and D. S. Yu in [16]: $\left\{c_{k}\right\} \in$ MVBVS (Mean Value Bounded Variation Sequences) if there exist constants $C$ and $\lambda \geq 2$ for which

$$
\sum_{k=n}^{2 n-1}\left|\Delta c_{k}\right| \leq \frac{C}{n} \sum_{k=[n / \lambda]}^{[\lambda n]}\left|c_{k}\right|
$$

is satisfied. MVBVS contains the monotone nonincreasing sequences and the previously used general monotone classes.

Definition. A sequence $\left\{c_{k}\right\} \subset \mathbb{C}$ is said to be a Supremum Bounded Variation Sequence, 
shortly $\left\{c_{k}\right\} \in$ SBVS, if there exist constant $C$ and $\lambda \geq 1$ depending only on $\left\{c_{k}\right\}$ such that

$$
\sum_{k=n}^{2 n-1}\left|\Delta c_{k}\right| \leq \frac{C}{n} \sup _{m \geq[n / \lambda]} \sum_{k=m}^{2 m}\left|c_{k}\right|
$$

holds for every $n \geq 1$.

Definition. We say that $\left\{c_{k}\right\} \subset \mathbb{C}$ sequence is a Supremum Bounded Variation Sequence of 2nd type, shortly $\left\{c_{k}\right\} \in \mathrm{SBVS}_{2}$, if there exist constant $C$ and $\{b(k)\}_{k=1}^{\infty} \subset \overline{\mathbb{R}}_{+}=[0, \infty)$ converging to infinity depending only on $\left\{c_{k}\right\}$ such that

$$
\sum_{k=n}^{2 n-1}\left|\Delta c_{k}\right| \leq \frac{C}{n} \sup _{m \geq b(n)} \sum_{k=m}^{2 m}\left|c_{k}\right| .
$$

Theorem 1.2.1. $\mathrm{SBVS}_{2} \supsetneqq \mathrm{SBVS} \supsetneqq \mathrm{MVBVS}$.

Theorem 1.2.2. Let $\left\{c_{k}\right\} \subset \mathbb{C}$ belong to class $\mathrm{SBVS}_{2}$.

(i) If

$$
k c_{k} \rightarrow 0 \quad \text { as } \quad k \rightarrow \infty
$$

then (1.1) converges uniformly in $x$.

(ii) Conversely, if $\left\{c_{k}\right\} \subset \overline{\mathbb{R}}_{+}$and (1.1) is uniformly convergent in $x$, then (1.2) holds.

Corollary 1.2.3. If $\left\{c_{k}\right\} \subset \overline{\mathbb{R}}_{+}$belongs to $\mathrm{SBVS}_{2}$, then (1.2) is a necessary and sufficient condition for the uniform convergence of (1.1) in $x$.

Remark 1.2.4. For any sequence from $\mathrm{SBVS}_{2}$ which is not in SBVS, (1.2) is satisfied. Hence sine series with coefficients from $\mathrm{SBVS}_{2} \backslash \mathrm{SBVS}$ are uniformly convergent.

In this section we also studied series of the form

$$
\sum_{k=1}^{\infty} k^{r} c_{k} \sin k x
$$

which is the formally differentiated series of (1.1) for positive even integer $r$ and is the formally integrated series of (1.1) for negative even integer $r$.

Theorem 1.4.1. If $\left\{c_{k}\right\}$ belongs to class MVBVS, then the sequence $\left\{d_{k}=k^{r} c_{k}\right\}$ also belongs to MVBVS for any fixed integer $r$.

Corollary 1.4.2. Let $\left\{c_{k}\right\} \in$ MVBVS be a complex sequence and $r$ a positive even integer.

(i) If $k^{r+1} c_{k} \rightarrow 0$, then (1.9) is uniformly convergent in $x$.

(ii) Conversely, if $\left\{c_{k}\right\} \subset \overline{\mathbb{R}}_{+}$and (1.9) is uniformly convergent in $x$, then $k^{r+1} c_{k} \rightarrow 0$.

Theorem 1.4.3. If $\left\{c_{k}\right\}$ belongs to SBVS, then $\left\{d_{k}=k^{r} c_{k}\right\}$ also belongs to SBVS for any fixed integer $r$.

Corollary 1.4.4. For $\left\{c_{k}\right\} \in$ SBVS and any positive even integer $r$, statements (i) and (ii) of Corollary 1.4.2 hold. 


\section{Double sine series}

Let $\left\{c_{j k}\right\}_{j, k=1}^{\infty} \subset \mathbb{C}$ and consider the double sine series of the form

$$
\sum_{j=1}^{\infty} \sum_{k=1}^{\infty} c_{j k} \sin j x \sin k y
$$

We give necessary and sufficient conditions for the above series to be uniformly convergent in the regular mean. The coefficients of the series are supposed to be from a class of general monotone double sequences.

Definition. A double sequence $\left\{c_{j k}\right\}_{j, k=1}^{\infty} \subset \mathbb{C}$ belongs to class MVBVDS (Mean Value Bounded Variation Double Sequences), if there exist $C$ and $\lambda \geq 2$ constants, depending only on $\left\{c_{j k}\right\}$, for which

$$
\begin{gathered}
\sum_{j=m}^{2 m-1}\left|\Delta_{10} c_{j n}\right| \leq \frac{C}{m} \sum_{j=[m / \lambda]}^{[\lambda m]}\left|c_{j n}\right|, \quad m \geq \lambda, n \geq 1, \\
\sum_{k=n}^{2 n-1}\left|\Delta_{01} c_{m k}\right| \leq \frac{C}{n} \sum_{k=[n / \lambda]}^{[\lambda n]}\left|c_{m k}\right|, \quad m \geq 1, n \geq \lambda, \\
\sum_{j=m}^{2 m-1} \sum_{k=n}^{2 n-1}\left|\Delta_{11} c_{j k}\right| \leq \frac{C}{m n} \sum_{j=[m / \lambda]}^{[\lambda m]} \sum_{k=[n / \lambda]}^{[\lambda n]}\left|c_{j k}\right|, \quad m, n \geq \lambda .
\end{gathered}
$$

Theorem 2.2.2. Let $\left\{c_{j k}\right\} \subset \mathbb{C}$ belong to MVBVDS.

(i) If

$$
j k c_{j k} \rightarrow 0 \text { as } \quad j+k \rightarrow \infty
$$

then the regular convergence of (2.1) is uniform in $(x, y)$.

(ii) Conversely, if $\left\{c_{j k}\right\} \subset \overline{\mathbb{R}}_{+}$and the regular convergence of (2.1) is uniform in $(x, y)$, then (2.2) holds.

Moreover, we proved that MVBVDS contains class NBVDS, which in turn contains the nonnegative, monotonically nonincreasing sequences. Later, we generalized further class MVBVDS and got the extension of Theorem 2.2.2.

Definition. $\left\{c_{j k}\right\}_{j, k=1}^{\infty} \subset \mathbb{C}$ is said to be a Supremum Bounded Variation Double Sequence of 1st type, in symbols: $\left\{c_{j k}\right\} \in \mathrm{SBVDS}_{1}$, if there exist constants $C$ and integer $\lambda \geq 2$ and sequences $\left\{b_{1}(l)\right\}_{l=1}^{\infty},\left\{b_{2}(l)\right\}_{l=1}^{\infty},\left\{b_{3}(l)\right\}_{l=1}^{\infty}$, each one converges to infinity, all of them depend only on $\left\{c_{j k}\right\}$, such that

$$
\sum_{j=m}^{2 m-1}\left|\Delta_{10} c_{j n}\right| \leq \frac{C}{m} \max _{b_{1}(m) \leq M \leq \lambda b_{1}(m)} \sum_{j=M}^{2 M}\left|c_{j n}\right|, \quad m \geq \lambda, n \geq 1,
$$




$$
\begin{gathered}
\sum_{k=n}^{2 n-1}\left|\Delta_{01} c_{m k}\right| \leq \frac{C}{n} \max _{b_{2}(n) \leq N \leq \lambda b_{2}(n)} \sum_{k=N}^{2 N}\left|c_{m k}\right|, \quad m \geq 1, n \geq \lambda, \\
\sum_{j=m}^{2 m-1} \sum_{k=n}^{2 n-1}\left|\Delta_{11} c_{j k}\right| \leq \frac{C}{m n} \sup _{M+N \geq b_{3}(m+n)} \sum_{j=M}^{2 M} \sum_{k=N}^{2 N}\left|c_{j k}\right|, \quad m, n \geq \lambda .
\end{gathered}
$$

Definition. $\left\{c_{j k}\right\}_{j, k=1}^{\infty} \subset \mathbb{C}$ is said to be a Supremum Bounded Variation Double Sequence of 2 nd type, shortly $\left\{c_{j k}\right\} \in \mathrm{SBVDS}_{2}$, if there exist constants $C$ and integer $\lambda \geq 1$ and $\{b(l)\}_{l=1}^{\infty}$ converging to infinity, depending only on $\left\{c_{j k}\right\}$, such that

$$
\begin{aligned}
\sum_{j=m}^{2 m-1}\left|\Delta_{10} c_{j n}\right| & \leq \frac{C}{m} \sup _{M \geq b(m)} \sum_{j=M}^{2 M}\left|c_{j n}\right|, \quad m \geq \lambda, n \geq 1, \\
\sum_{k=n}^{2 n-1}\left|\Delta_{01} c_{m k}\right| & \leq \frac{C}{n} \sup _{N \geq b(n)} \sum_{k=N}^{2 N}\left|c_{m k}\right|, \quad m \geq 1, n \geq \lambda, \\
\sum_{j=m}^{2 m-1} \sum_{k=n}^{2 n-1}\left|\Delta_{11} c_{j k}\right| & \leq \frac{C}{m n} \sup _{M+N \geq b(m+n)} \sum_{j=M}^{2 M} \sum_{k=N}^{2 N}\left|c_{j k}\right|, \quad m, n \geq \lambda .
\end{aligned}
$$

Theorem 2.5.1. SBVDS $_{2} \supsetneqq$ SBVDS $_{1} \supsetneqq$ MVBVDS.

Theorem 2.5.2. (i) If $\left\{c_{j k}\right\} \subset \mathbb{C}$ belongs to $\mathrm{SBVDS}_{2}$ and (2.2) is satisfied, then the regular convergence of (2.1) is uniform in $(x, y)$.

(ii) Conversely, if $\left\{c_{j k}\right\} \subset \overline{\mathbb{R}}_{+}$belongs to $\mathrm{SVBVDS}_{1}$ and the regular convergence of (2.1) is uniform in $(x, y)$, then (2.2) holds.

\section{Sine integrals}

In this section we study the uniform convergence of the sine integrals

$$
\int_{0}^{\infty} f(x) \sin t x d x
$$

in $t$, where function $f: \mathbb{R}_{+} \rightarrow \mathbb{C}$ is Lebesgue measurable, $\mathbb{R}_{+}:=(0, \infty), t \in \mathbb{R}$ and

$$
x f(x) \in L_{\mathrm{loc}}^{1}\left(\overline{\mathbb{R}}_{+}\right) .
$$

We expand class $\operatorname{MVBVF}\left(\mathbb{R}_{+}\right)$defined in [10], which class contains the nonnegative, nonincreasing, locally absolutely continuous functions defined on $\mathbb{R}_{+}$, hence we extend the results of the that paper.

Definition. A function $f(x) \in \mathrm{AC}_{\text {loc }}^{1}\left(\mathbb{R}_{+}\right)$is said to belong to class $\operatorname{SBVF}\left(\mathbb{R}_{+}\right.$) (Supremum Bounded Variation Functions) if there exist constants $C, A>0$ and $\lambda \geq 2$ which depend only on $f$ and satisfy condition

$$
\int_{a}^{2 a}\left|f^{\prime}(x)\right| d x \leq \frac{C}{a} \sup _{b \geq a / \lambda} \int_{b}^{2 b}|f(x)| d x, \quad a>A .
$$


Definition. A function $f(x) \in \mathrm{AC}_{\text {loc }}\left(\mathbb{R}_{+}\right)$is said to be in class $\mathrm{SBVF}_{2}\left(\mathbb{R}_{+}\right)$(Supremum Bounded Variation Functions of 2nd type), if there exist constants $C, A>0$ and function $B(x) \subset \overline{\mathbb{R}}_{+}$tending to infinity, depending only on $f$, such that

$$
\int_{a}^{2 a}\left|f^{\prime}(x)\right| d x \leq \frac{C}{a} \sup _{b \geq B(a)} \int_{b}^{2 b}|f(x)| d x, \quad a>A .
$$

Theorem 3.2.1. If $f(x) \in \operatorname{MVBVF}\left(\mathbb{R}_{+}\right)$, then $f(x) \in \operatorname{SBVF}\left(\mathbb{R}_{+}\right)$. The reverse implication is not true, in other words, there exists an $f(x) \in \operatorname{SBVF}\left(\mathbb{R}_{+}\right)$which is not in $\operatorname{MVBVF}\left(\mathbb{R}_{+}\right)$. $\operatorname{Shortly,~} \operatorname{SBVF}\left(\mathbb{R}_{+}\right) \supsetneqq \operatorname{MVBVF}\left(\mathbb{R}_{+}\right)$.

Theorem 3.2.2. $\mathrm{SBVF}_{2}\left(\mathbb{R}_{+}\right) \supsetneqq \operatorname{SBVF}\left(\mathbb{R}_{+}\right)$. Furthermore, if $f(x) \in \mathrm{SBVF}_{2}\left(\mathbb{R}_{+}\right) \backslash \mathrm{SBVF}\left(\mathbb{R}_{+}\right)$, then

$$
x f(x) \rightarrow 0, \text { ha } x \rightarrow \infty .
$$

Theorem 3.2.3. Suppose that $f(x) \in \mathrm{SBVF}_{2}\left(\mathbb{R}_{+}\right)$and (3.2) is satisfied.

(i) If $f: \mathbb{R}_{+} \rightarrow \mathbb{C}$ and (3.3) holds, then integral (3.1) converges uniformly in $t$.

(ii) Conversely, if $: \mathbb{R}_{+} \rightarrow \overline{\mathbb{R}}_{+}$and (3.1) converges uniformly in t, then (3.3) holds.

Finally we described the uniform convergence of the sine integrals

$$
\int_{0}^{\infty} x^{r} f(x) \sin t x d x
$$

which are the formally differentiated integrals of (3.1) for positive even integer $r$ and are the formally integrated integrals of (3.1) for negative even integer $r$.

Theorem 3.4.1. Suppose that $f(x) \in \operatorname{MVBVF}\left(\mathbb{R}_{+}\right)$. Then $g_{r}(x)=x^{r} f(x)$ also belongs to $\operatorname{MVBVF}\left(\mathbb{R}_{+}\right)$for any fixed integer $r$.

Corollary 3.4.2. Assume that $f(x) \in \operatorname{MVBVF}\left(\mathbb{R}_{+}\right)$with property (3.2) and $r$ is a positive even integer.

(i) If $f: \mathbb{R}_{+} \rightarrow \mathbb{C}$ and $x^{r+1} f(x) \rightarrow 0$ as $x \rightarrow \infty$, then the sine integral (3.10) converges uniformly in $t$.

(ii) Conversely, if $f: \mathbb{R}_{+} \rightarrow \overline{\mathbb{R}}_{+}$and (3.10) converges uniformly in t, then $x^{r+1} f(x) \rightarrow 0$ as $x \rightarrow \infty$.

For any negative even integer $r$ the above statements remain true if $x^{r+1} f(x) \in L_{\text {loc }}^{1}\left(\overline{\mathbb{R}}_{+}\right)$.

Theorem 3.4.3. Suppose that $f(x) \in \operatorname{SBVF}\left(\mathbb{R}_{+}\right)$. Then $g_{r}(x)=x^{r} f(x) \in \operatorname{SBVF}\left(\mathbb{R}_{+}\right)$for any fixed positive integer $r$.

Corollary 3.4.4. If we assume $f(x) \in \operatorname{SBVF}\left(\mathbb{R}_{+}\right)$with property (3.2) and $r$ is an even positive integer, then statements (i) and (ii) of Corollary 3.4 .2 hold. 


\section{Double sine integrals}

Consider the double sine integrals of the form

$$
\int_{0}^{\infty} \int_{0}^{\infty} f(x, y) \sin u x \sin v y d x d y, \quad(u, v) \in \mathbb{R}^{2}
$$

where $f(x, y): \mathbb{R}_{+}^{2} \rightarrow \mathbb{C}$ is a Lebesgue measurable function. We suppose that the twovariable function $f$ is locally absolutely continuous, general monotone and

$$
x y f(x, y) \in L_{\mathrm{loc}}^{1}\left(\overline{\mathbb{R}}_{+}^{2}\right) .
$$

Definition. A function $f(x, y) \in \mathrm{AC}_{\text {loc }}\left(\mathbb{R}_{+}^{2}\right)$ is said to be in class $\operatorname{MVBVF}\left(\mathbb{R}_{+}^{2}\right)$, if there exist constants $C$ and $\lambda \geq 2$ depending only on $f$, such that

$$
\begin{gathered}
\int_{a_{1}}^{2 a_{1}}\left|f_{x}(x, y)\right| d x \leq \frac{C}{a_{1}} \int_{a_{1} / \lambda}^{\lambda a_{1}}|f(x, y)| d x, \quad a_{1}, y>0, \\
\int_{a_{2}}^{2 a_{2}}\left|f_{y}(x, y)\right| d y \leq \frac{C}{a_{2}} \int_{a_{2} / \lambda}^{\lambda a_{2}}|f(x, y)| d y, \quad x, a_{2}>0, \\
\int_{a_{1}}^{2 a_{1}} \int_{a_{2}}^{2 a_{2}}\left|f_{x y}(x, y)\right| d x d y \leq \frac{C}{a_{1} a_{2}} \int_{a_{1} / \lambda}^{\lambda a_{1}} \int_{a_{2} / \lambda}^{\lambda a_{2}}|f(x, y)| d x d y, \quad a_{1}, a_{2}>0 .
\end{gathered}
$$

Theorem 4.2.2. Suppose that $f \in \operatorname{MVBVF}\left(\mathbb{R}_{+}^{2}\right)$ with property (4.3).

(i) If $f: \mathbb{R}_{+}^{2} \rightarrow \mathbb{C}$ and

$$
x y f(x, y) \rightarrow 0 \quad \text { as } \quad x+y \rightarrow \infty,
$$

then the regular convergence of (4.1) is uniform in $(u, v) \in \mathbb{R}_{+}^{2}$.

(ii) Conversely, if $f: \mathbb{R}_{+}^{2} \rightarrow \overline{\mathbb{R}}_{+}$and the regular convergence of (4.1) is uniform in $(u, v)$, then (4.10) holds.

Furthermore, we proved that $\operatorname{MVBVF}\left(\mathbb{R}_{+}^{2}\right)$ contains class $\operatorname{NBVF}\left(\mathbb{R}_{+}^{2}\right)$, which is larger than the class of nonnegative, nonincreasing, locally absolutely continuous functions defined on $\mathbb{R}_{+}^{2}$.

Corollary 4.2.4. If $f: \mathbb{R}_{+}^{2} \rightarrow \overline{\mathbb{R}}_{+}$is monotonically nonincreasing and $f \in \mathrm{AC}_{\mathrm{loc}}\left(\mathbb{R}_{+}^{2}\right)$, then (4.10) is necessary and sufficient for the regular convergence of (4.1) to be uniform in $(u, v)$. 